San Jose State University

SJSU ScholarWorks

Master's Theses

Master's Theses and Graduate Research

Spring 2013

\title{
Geophysical Expression of the Northern Part of the Mono-Inyo Volcanic Chain, Mono Basin, California
}

Amanda McDonell

San Jose State University

Follow this and additional works at: https://scholarworks.sjsu.edu/etd_theses

\section{Recommended Citation}

McDonell, Amanda, "Geophysical Expression of the Northern Part of the Mono-Inyo Volcanic Chain, Mono Basin, California" (2013). Master's Theses. 4290.

DOI: https://doi.org/10.31979/etd.qy6u-n7hn

https://scholarworks.sjsu.edu/etd_theses/4290

This Thesis is brought to you for free and open access by the Master's Theses and Graduate Research at SJSU ScholarWorks. It has been accepted for inclusion in Master's Theses by an authorized administrator of SJSU ScholarWorks. For more information, please contact scholarworks@sjsu.edu. 


\title{
GEOPHYSICAL EXPRESSION OF THE NORTHERN PART OF THE MONO- INYO VOLCANIC CHAIN, MONO BASIN, CALIFORNIA
}

\author{
A Thesis \\ Presented to \\ The Faculty of the Department of Geology \\ San Jose State University \\ In partial fulfillment \\ Of the requirements for the degree \\ Masters of Science
}

by

Amanda Pera McDonell

May 2013 
(C) 2013

Amanda Pera McDonell

ALL RIGHTS RESERVED 
The Designated Committee Approves the Thesis Titled

\section{GEOPHYSICAL EXPRESSION OF THE NORTHEN PART OF THE MONO-INYO} VOLCANIC CHAIN, MONO BASIN, CALIFORNIA

by

Amanda Pera McDonell

APPROVED FOR THE DEPARTMENT OF GEOLOGY

SAN JOSE STATE UNIVERSITY

May 2013
Dr. Jonathan Miller
Department of Geology
Dr. Maurizio Battaglia
Department of Geology
Dr. Richard Sedlock
Department of Geology
Dr. Darcy McPhee
U.S. Geological Survey 


\begin{abstract}
GEOPHYSICAL EXPRESSION OF THE NORTHERN PART OF THE MONOINYO VOLCANIC CHAIN, MONO BASIN, CALIFORNIA

by Amanda Pera McDonell
\end{abstract}

The Mono Domes are located at the northernmost end of the Mono-Inyo volcanic chain just north of the Long Valley Caldera and include more than 30 overlapping domes and coulees that follow an arcuate trend. A shallow basement high, possibly bounded by a fault, as suggested by potential-field models of data collected in Mono Basin, California, may have influenced the geometry and location of the Mono Domes.

Over 320 new gravity stations and approximately 297 line-km of ground magnetic data were collected during the summer of 2010 to investigate the subsurface structure of the Mono Basin. Regional gravity data were collected throughout the basin, and ground magnetic data were collected on major roads along numerous transects throughout the region, one of which was coincident with a seismic refraction line. Gravity and magnetic data were compiled with pre-existing data from studies dating back to the 1960's to produce a new regional isostatic gravity anomaly map and ground magnetic profiles throughout the basin.

Aeromagnetic and ground magnetic data revealed an anomalous ring-shaped magnetic high centered over Aeolian Buttes, whose eastern margin follows the arcuate trend of the Mono Domes. This magnetic high is essentially coincident with what Kistler 
(1966) inferred to be a ring-fracture. Two-dimensional forward modeling of potential field data along a profile across the basin suggests a basement high, or ridge, at roughly $700 \mathrm{~m}$ depth, the eastern edge of which lies beneath the Mono Domes. The basement ridge is probably fractured, as suggested by potential field data, indicating a possible preexisting fault beneath the Mono Domes. This fault is along the eastern edge of the basement ridge and could have served as a conduit for the Mono Domes feeder dike. 


\section{ACKNOWLEGEMENTS}

This thesis project would not have been possible without the support of many people. My deepest appreciation goes to my thesis committee for their continued encouragement and support. I would like to thank Dr. Jonathan Miller for having confidence in me and giving me the opportunity to work on this project. I would also like to thank Dr. Maurizio Battaglia for taking me on as a student and providing invaluable guidance throughout the thesis. It is an honor to have had Dr. Maggie Mangan as a supervisor and mentor and to have her support and encouragement, and for introducing me to the GUMP group. I am very fortunate to have been under the supervision of such an amazing woman/scientist. I owe my deepest gratitude to Dr. Darcy McPhee and Dave Ponce for teaching me more than any potential field geophysics book or class could have ever taught me, and for opportunities I would have never had without their help. I cannot find the words to express my appreciation to Dave for his mentoring and advising through every aspect of this work and for his patience and understanding, no matter how small the question. It was a privilege to work with both Darcy and Dave and never in my dreams would I have expected a thesis project to be as fun and exciting as this was; I will never forget my experience working with everyone at the USGS. I would also like to thank Erin Looby, John Spritzer, Bruce Chuchle, Janet Watt, Dave Hill, Mae Marcaida, Kevin Denton, Carole Tomasello, and Angela Jayko for their help and support in the field and the office. 


\section{TABLE OF CONTENTS}

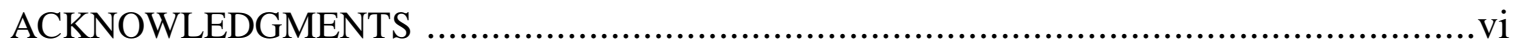

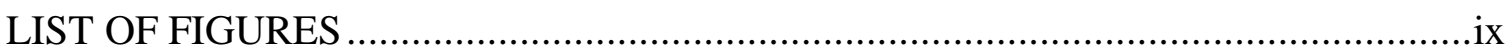

LIST OF TABLES .....................................................................................

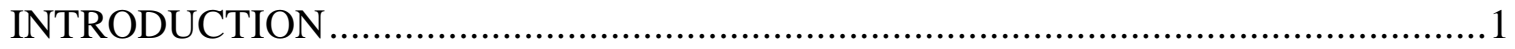

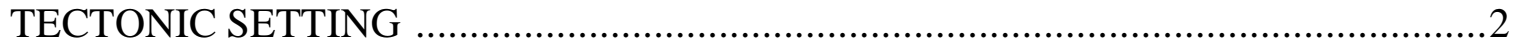

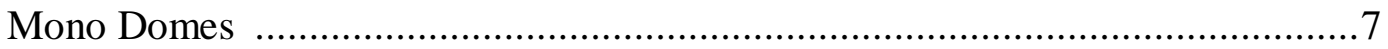

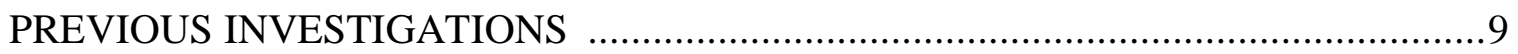

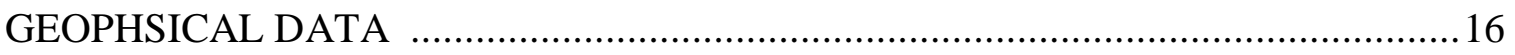

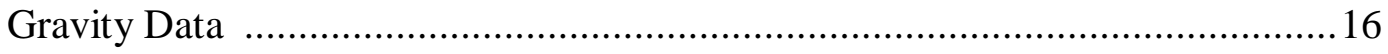

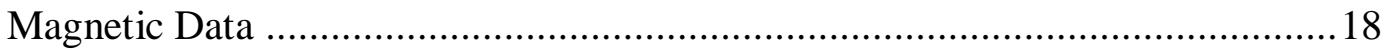

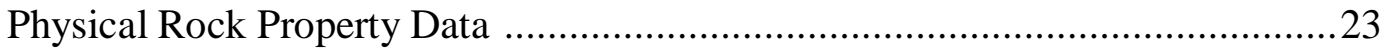

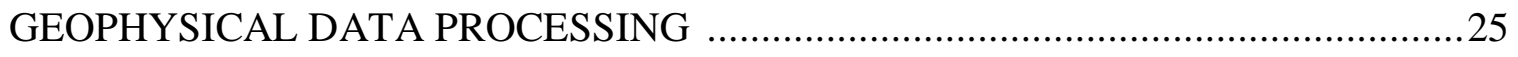

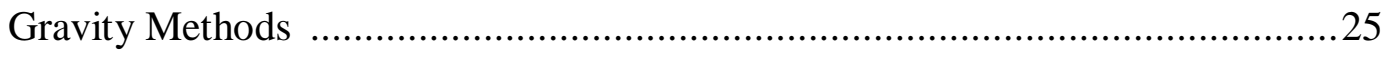

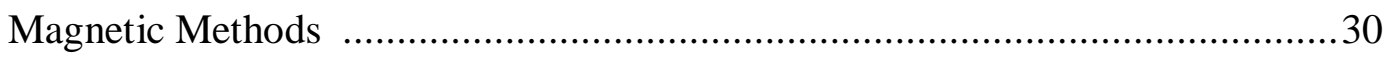

Reduction-to-the-magnetic Pole .......................................................30

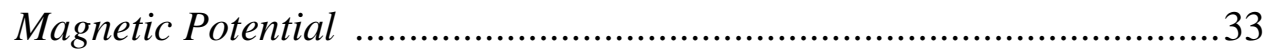

Maximum Horizontal Gradients ..................................................34 
MODELING

DISCUSSION

CONCLUSIONS

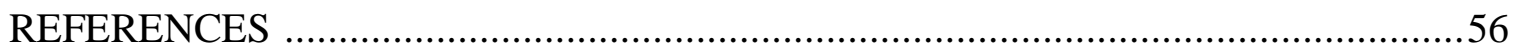

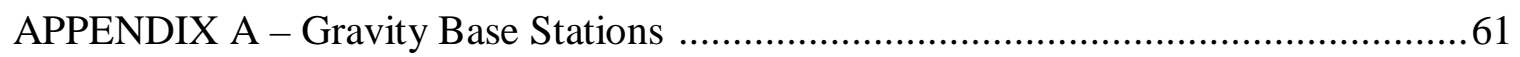

APPENDIX B - Physical Rock Property Data ………....................................................64

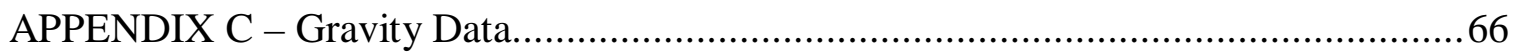

APPENDIX D - Truck-towed Magnetic Profiles ……………………………............76 


\section{LIST OF FIGURES}

Figure 1 - Index map of the Mono Basin study area................................................

Figure 2 - Generalized geologic map of the Mono Basin Study area..........................4

Figure 3 - Tectonic/Structural map of eastern California and western Nevada ...............6

Figure 4 - Geologic map of Mono Domes from Bailey (1989) .................................8

Figure 5a and $\mathbf{5 b}$ - Lithologic columns of geothermal wells from the shores of Mono Lake

Figure 6a and $\mathbf{6 b}$ - Index map and seismic refraction model from Hill and others (1985).

Figure 7 -- Modified geologic map of ring fracture from Kistler (1966) ......................15

Figure 8 - Map of gravity station locations from summer 2010 field work ...................17

Figure 9 - Aeromagnetic survey flight-line specifications from Roberts and Jachens (1999)

Figure 10 - Aeromagnetic anomaly map of the Mono Basin study area ......................21

Figure 11 - Truck-towed and ground magnetic line map of transects from summer 2010 field work

Figure 12 - Rock sample location map of samples collected for physical rock property measurements

Figure 13 - Isostatic gravity anomaly map of the Mono Basin study area. .26

Figure 14 - Truck-towed and ground magnetic anomaly map of the Mono Basin study area.

Figure 15 - Reduction-to-the-pole magnetic map of the Mono Basin study area

Figure 16 - Magnetic potential map of the Mono Basin study area.....

Figure 17 - Isostatic gravity anomaly map with maximum horizontal gradients of the Mono Basin study area .35

Figure 18 - Aeromagnetic anomaly map with maximum horizontal gradients of the Mono Basin study area

Figure 19 - Residual anomaly map of the upper $1 \mathrm{~km}$ of crust in the Mono Basin study area. 


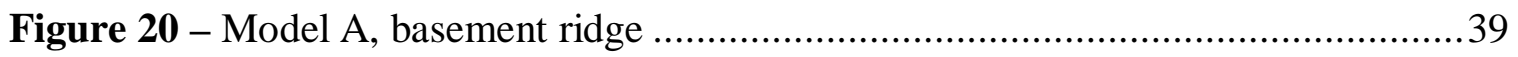

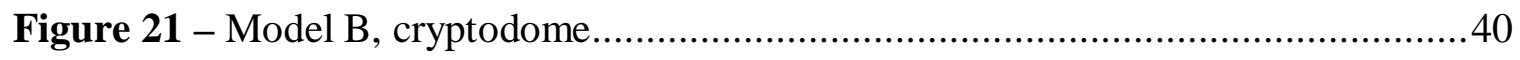

Figure 22 - Seismic velocity model from Hill and others (1985) .............................43

Figure 23 - Cryptodome model from Shaffer and others (2010) .............................46

Figure 24 - Ground magnetic profile of transect across the Mono Domes ...................48

Figure 25 - Aeromagnetic data overlaid with ground magnetic data of the Mono Basin

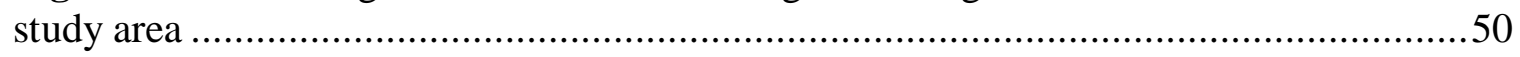

Figure 26 -- Interpretive map of circular shaped magnetic anomaly in Pumic Valley ....53 


\section{LIST OF TABLES}

Table 1 - Aeromagnetic survey specifications...................................................19

Table 2 - Physical rock property measurements of selected rock types collected during

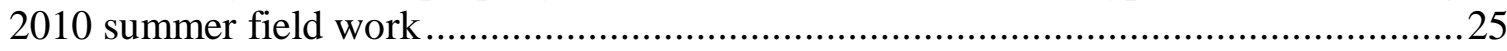

Table 3 - Velocity to density conversions ..................................................... 41

Table 4 - Model parameters ...................................................................... 45 


\section{INTRODUCTION}

Geological studies suggest that of the several systems that form the Long Valley volcanic region (eastern California), the Mono Domes volcanic chain located in the Mono Basin appears to hold the greatest potential for renewed magmatic activity (Hildreth, 2004). Although the Mono Domes represent some of the youngest foci of volcanic activity in the region, the latest geophysical investigations were conducted in the mid-1980’s, more than twenty years ago.

The Mono Basin is also a region of geothermal interest. The Long Valley caldera is located just south of the Mono Basin and is home to the Casa Diablo geothermal plant, which generates roughly 40 megawatts of electricity for Mammoth Pacific. Because the Mono Basin is a volcanically active area with the most recent eruption only 250 years ago, the region may hold geothermal potential.

In an attempt to characterize and explore the subsurface structure of Mono Basin several geophysical studies were conducted. Previous gravity and magnetic investigations focused on the depth, geometry, density distribution, and magnetization of Mono Basin (Pakiser and others, 1960; Gilbert and others, 1968; Christensen, 1969; Pakiser 1976). Other studies with geothermal motivations were conducted to determine the depth and geometry of a possible magma source beneath Mono Domes (Hermance and others, 1984; Hill and others, 1985; Achauer and others, 1986). However, many contrasting conclusions have been drawn from these works, and few constraints have been placed on the density distribution and subsurface structure across the Mono Domes. 
In the summer of 2010, we collected new regional gravity and ground magnetic data in and around the Mono Domes to improve the gravity and magnetic coverage throughout the region. New gravity data were compiled with an existing gravity database (Battaglia et al, 2003) to produce a new regional isostatic gravity anomaly map. In addition, a ground magnetic anomaly map was also produced from the newly collected data. Utilizing the new data and modern technology, such as state-of-the-art Geographic Positioning System (GPS) equipment and modeling software, we were able to provide a fresh interpretation of the Mono Domes subsurface structure.

In this work, we presented two-dimensional subsurface models derived from the integrated gravity and existing aeromagnetic data that better constrain the density and magnetization distribution, depth, and structure of the Mono Domes region within the Mono Basin. These efforts were critical to improving the dynamic modeling of active range front-faulting and eruptions by dike intrusion in the Mono Basin (e.g., Bursik and others, 2003). The structural model based on the regional gravity and magnetic surveys provided a useful framework to better assess the potential geothermal resources and volcanic hazards of the region.

\section{TECTONIC SETTING}

The Mono Basin is bounded by the Bodie Hills on the north, Long Valley Caldera on the south, Cowtrack Mountains on the east, and the Sierra Nevada on the west (Fig. 1). The majority of the basin consists of quaternary alluvium, tertiary volcanic rocks, and pre-Cenozoic rocks including granitic basement and metasedimentary rocks (Fig. 2). 


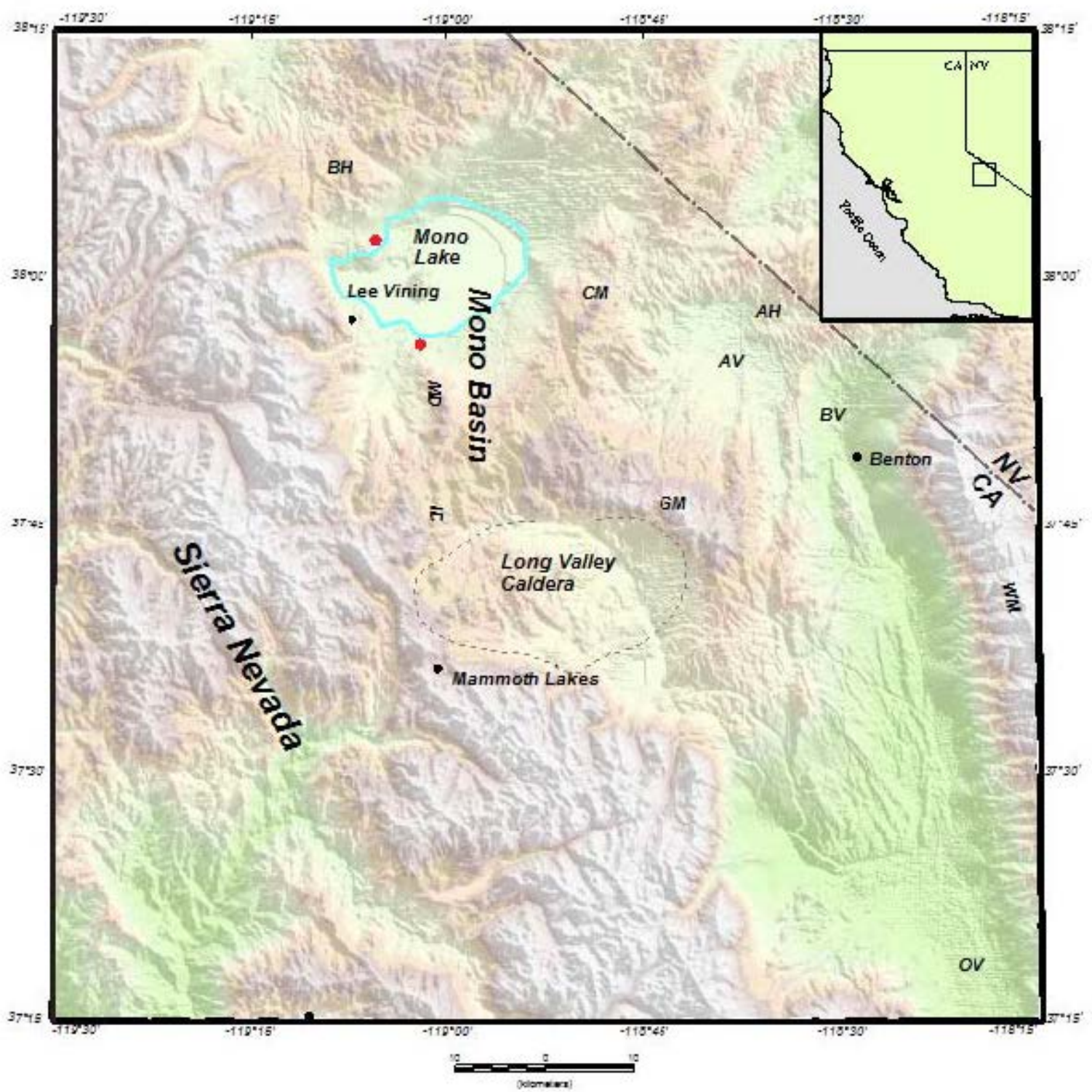

Figure 1. Index map of the Mono Basin study area. BH, Bodie Hills; CM, Cowtrack Mountain; AH, Adobe Hills; AV, Adobe Valley; MD, Mono Domes; ID, Inyo domes; GM, Glass Moutain; WM, White Mountains; OV, Owens Valley; BV, Benton Valley. Black box in inset map shows the map location in California and Nevada. Red dots show approximate locations of geothermal wells (Axtell, 1972), "State PRC 4572.1" located on the northwest shore and "State PRC 4397.1" is located on the south shore of Mono Lake. 


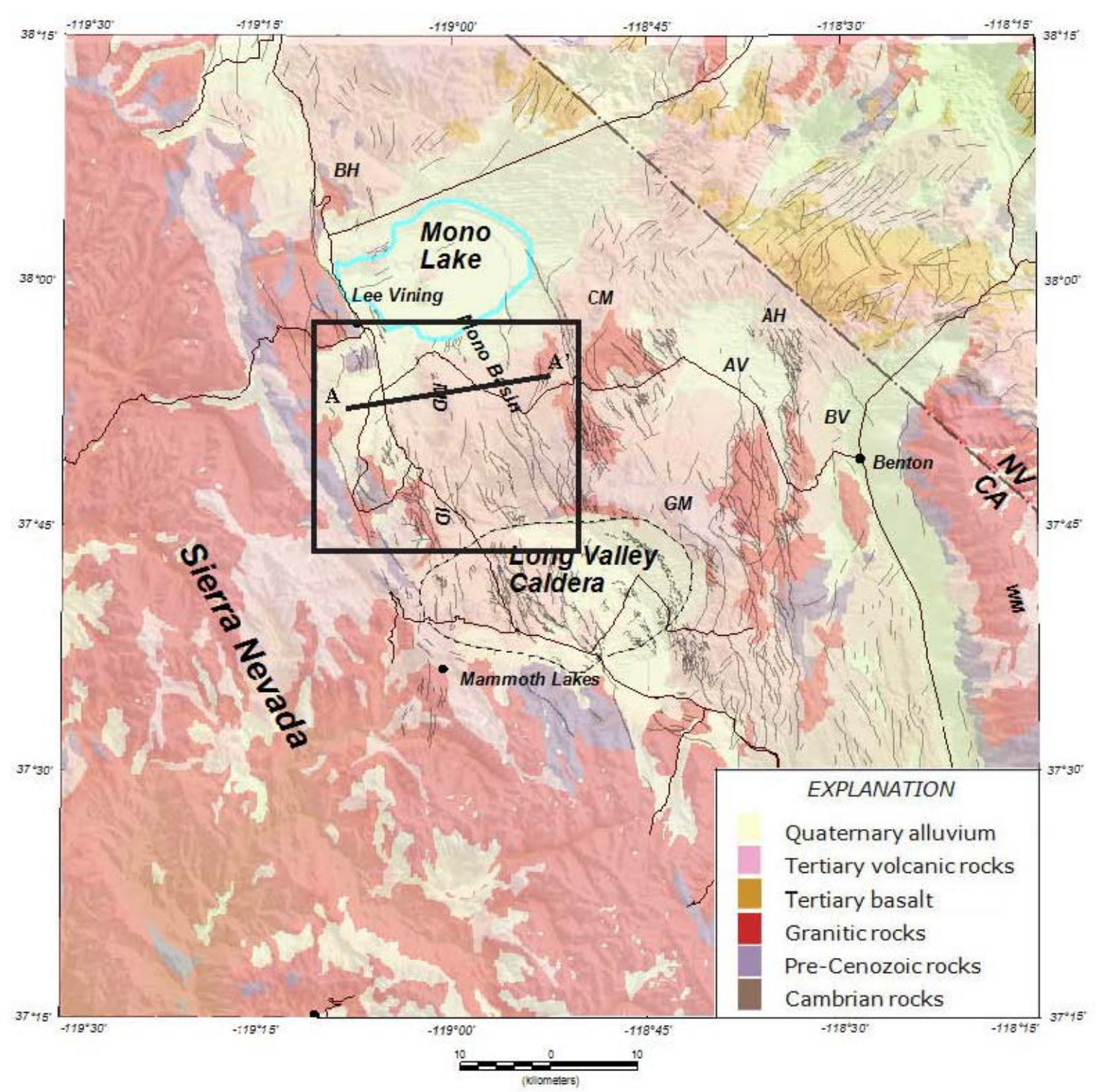

Figure 2. Simplified geologic map of the study area shown in Figure 1, modified from Jenning and others (1977) and Stewart and Carlson (1978). Grey lines represent faults from Bailey (1989) and Jennings and others (1977). The black box shows location of Figure 4. Profile A-A' shows location of the potential field model.

Mesozoic basement rocks within Mono Basin consists of quartz monzonite, granodiorite, diorite, gabbro, and other granitic rocks (Kistler, 1966; Bailey, 1989). The Mono Basin is located to the north of the Owens Valley graben in a left-lateral step in the 
eastern escarpment of the Sierra Nevada. The basin lies on the western boundary of the Basin and Range Province, adjacent to large east-dipping normal faults of the eastern Sierra Nevada escarpment. Volcanism and tectonic deformation in this zone are contemporaneous, and most likely associated with the upwelling of magma into the crust from the underlying asthenosphere as the crust stretches, thins, and occasionally fractures in response to transtensional deformation (Hill, 2006).

Post-Miocene volcanism in the Mono Basin is related to the northern extensional Eastern California Shear Zone (ECSZ) and its continuation to the north along the southern Walker Lane Belt (WLB) in western Nevada (Fig. 3). This region has been tectonically influenced by extension of the crust across the Basin and Range to the west and by strike-slip motion along the Pacific and North American transform plate boundary (Hill, 2006). Dextral slip across the transtensional ECSZ and WLB accounts for 15-25\% of the relative Pacific and North American plate motion, most of which is not on the San Andreas Fault System (Henry and Faulds, 2005). Linking the ECSZ and the WLB is the Mina Deflection (Fig. 3), a zone of several large pull-apart structures that are structurally controlled by NE-striking normal faults that transfer slip from the ECSZ to WLB, in which slip transfer is accommodated along dextral, sinistral and normal faults (Lee and Stockli, 2005). The Mina Deflection along with a 100-km wide topographic swell centered on the Mono Basin has been a significant component in Pliocene to recent volcanism within the region (Hill, 2006). 


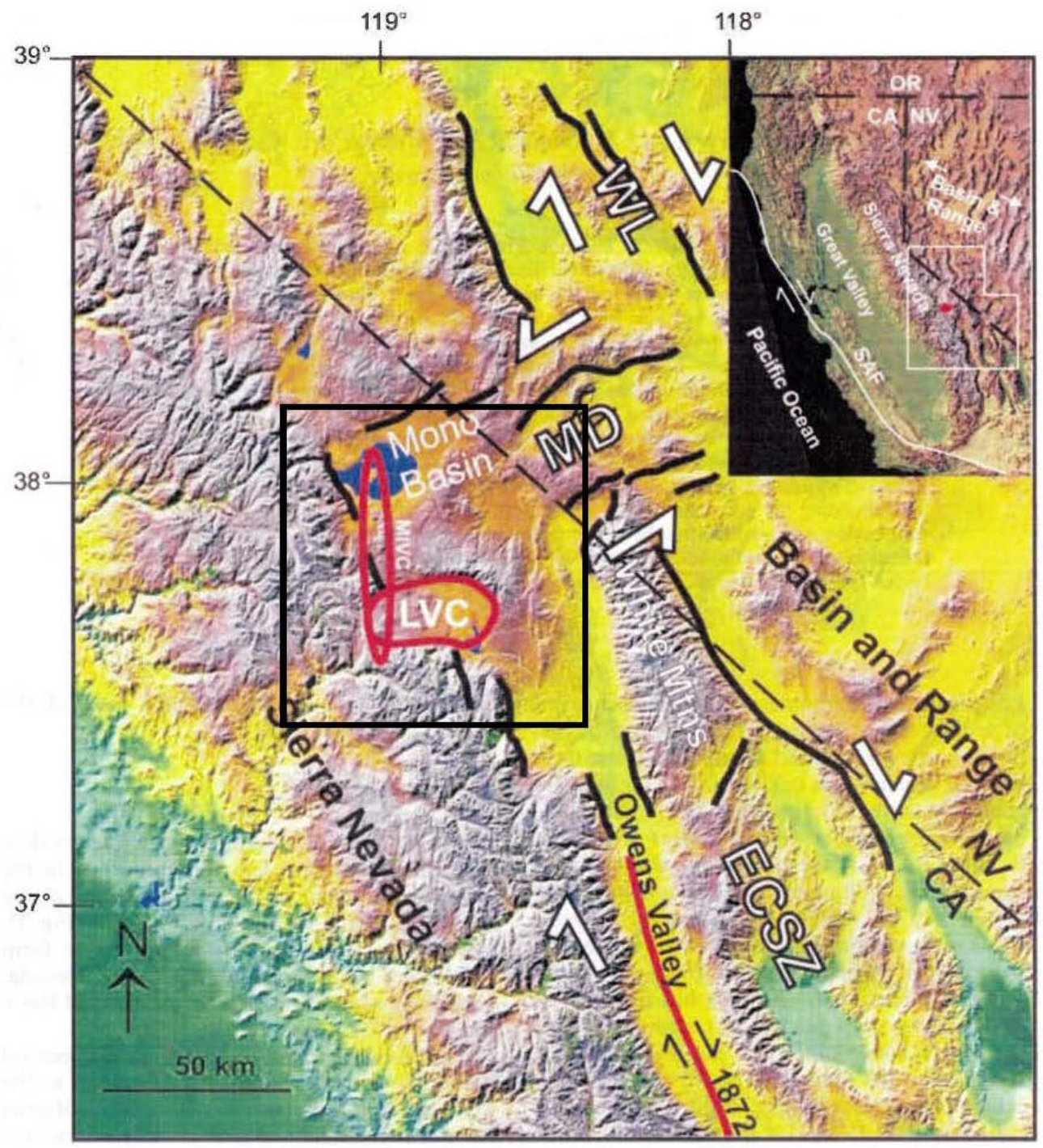

Figure 3. Map of eastern California and western Nevada (Hill, 2006) showing the direction of displacement along the Walker Lane belt (WL), the Mina deflection (MD), and the Eastern California Shear Zone (ECSZ). The location of the Mono-Inyo volcanic chain (MIVC) is shown by the north-south elongated red oval. Solid black lines indicate major Quaternary faults. The Long Valley Caldera (LVC) is outlined in red. The black box outlines the study area. 


\section{Mono Domes}

The Mono Domes are defined by a 17-km long arcuate ridge of over 30 domes, coulees, and explosion domes between June Lake and Mono Lake (Fig. 4). The ridge has

a maximum elevation of 2,800 m. Volcanic activity of the Mono Domes began $40 \mathrm{ka}$ and continued through recent times. All but one of the Mono Domes lavas are composed of high-silica rhyolite. Most of the lavas are Holocene in age, three are approximately 13 ka, and one is 20 ka (Hildreth, 2004). The older Mono Domes (40-3 ka) are porhyritic and the younger domes ( $3 \mathrm{ka}-550 \mathrm{yr}$ ) are aphyric, suggesting a rise in temperature in the magma chamber or the source coming from a greater depth (Bailey, 1989). A group of young vents within and adjacent to Mono Lake follow the approximate trend of the Mono Domes. However, they are compositionally different and are considered to be independent of the magma reservoir that supplies the Mono Domes (Hildreth, 2004).

The youngest eruptions at the north end of Mono Domes are dated at $660 \pm 20 \mathrm{yr}$ and may have been be fed by a 6 km-long dike (Bursik and Sieh, 1989). The eruptions of the North Mono Domes were followed by the most recent eruption of the Inyo Domes. The interval between the eruptions is believed to be between one to two years as suggested by minor disturbances of the North Mono tephra prior to deposition of the Inyo tephra and the time frame of activity is indicative of a genetic relationship (Sieh and Bursik, 1986). 


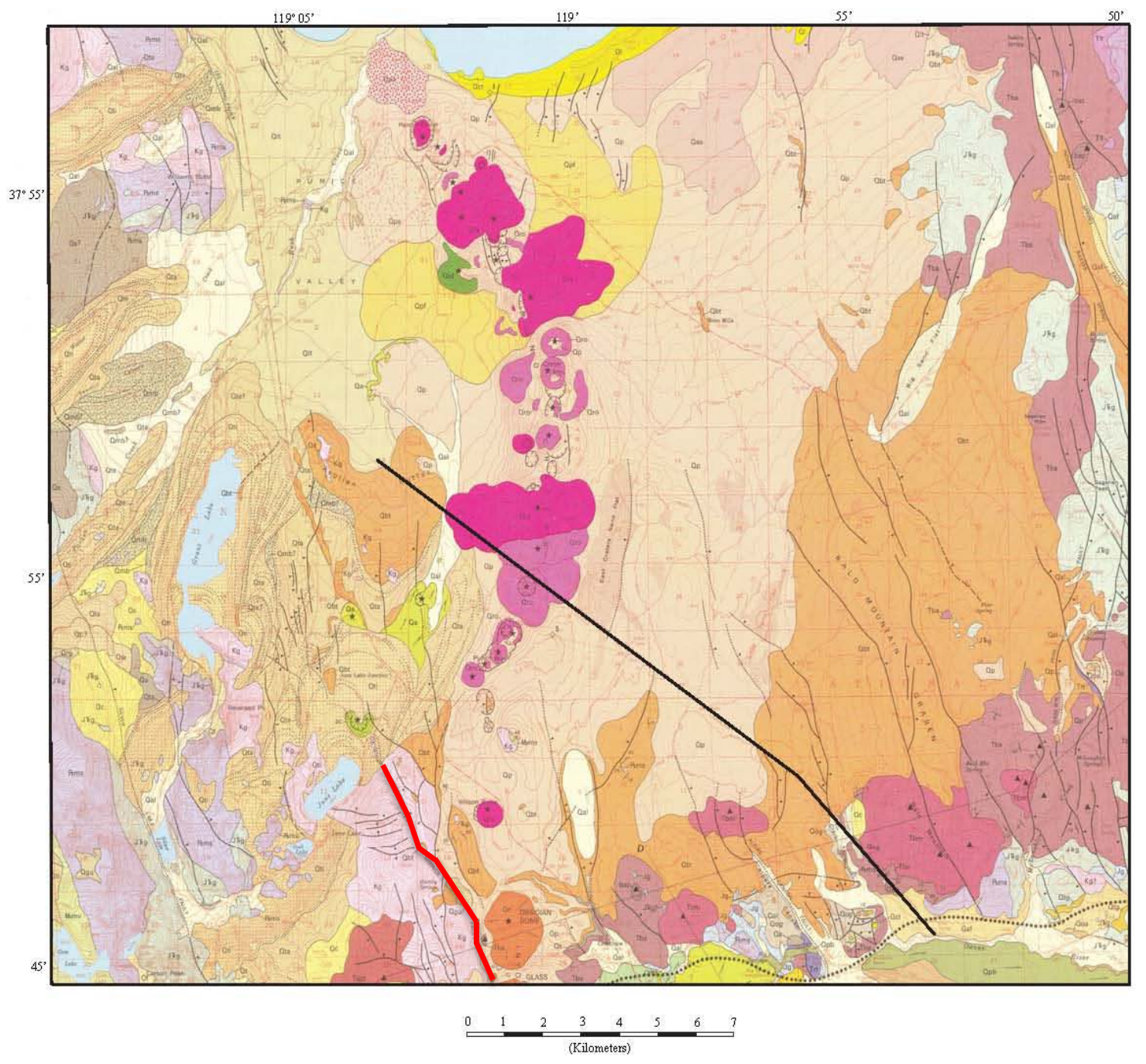

Figure 4. Modified geologic map of the Mono Basin study area (Bailey, 1989). Bold black line shows the approximate location of the Mono Craters Tunnel, red line shows the approximate location of the Hartley Springs Fault. Magenta, Mono Domes; Orange, Bishop Tuff; Tan, Alluvium; Pink, Basalt. Note map scale differs from Figure 1 and 2.

Stratigraphic investigations throughout the Mono Basin indicate that the explosive events of the North Mono and Inyo eruption sequences were accompanied by a series of strong earthquakes, most likely on the Hartley Springs Fault which runs from the southern-most end of the Mono Domes southward along the Inyo Domes, ending at Glass 
Creek Flow (Fig. 4). The seismic events may have been triggered by dike emplacement near the fault (Bursik and others, 2003). Slipon the causes zones of low confinement stress, which allowed magma to be drawn up and erupt.

Two different hypotheses regarding the geometry of the Mono Domes can be found in the literature. (1) The Mono Domes are fed by a ring dike and erupted along the mylonitized border of a subcircular Cretacous pluton centered on Aeolian Buttes, which are composed of Bishiop Tuff and granitic rock ( Kistler, 1966; Bailey and others, 1976; Bailey, 1982, 1989). (2) The Mono Domes formed along an extensional boundary of a pull-apart basin, defined by the north-northwest-striking faults of the Sierran range front in the Mono Basin that are oblique-slip faults with a right-lateral component (Bursik and Sieh, 1989). Hildreth (2004) suggested that the latter is more likely because the evidence for the mylonitic zone is poorly exposed in only three out crops along the pluton border.

\section{PREVIOUS INVESTIGATIONS}

Construction in the late 1930's and early 1940's of the Los Angeles water tunnel, known as the Mono Craters tunnel, provides detailed stratigraphic information along a transect across the Mono Basin. The West Portal of the tunnel is located $12.8 \mathrm{~km}$ southeast of the town of Lee Vining; the East Portal is about $18.2 \mathrm{~km}$ to the southeast near Aeolian Buttes (Fig. 4). Logs from several test holes and shafts drilled from the surface provide data for a simplified geologic profile along the tunnel transect (Gresswell, 1940; Jacques, 1940). Gresswell (1940) describes a wide fault zone beneath the axis of the Mono Domes encountered during the drilling of the water tunnel. In 
addition to the tunnel, two geothermal wells were drilled on the shores of Mono Lake in 1971 (Axtell, 1972; see Fig. 1). Well "State PRC 4397.1” was drilled to an approximate depth of $1 \mathrm{~km}$ on the south shore and well "State PRC 4572.1" reached a depth of $0.7 \mathrm{~km}$ on the northwest shore of Mono Lake. Detailed lithologic logs are available for both wells (Fig. 5a and 5b). The temperature of the drilling mud for well "State PRC 4397.1" was continuously monitored and recorded. The average temperature of the returning mud was $29^{\circ} \mathrm{C}$ at the surface and increased gradually to a maximum of $46^{\circ} \mathrm{C}$ at the bottom of the well. Weathered basement was reached at a depth of approximately $0.5 \mathrm{~km}$.

Interpretation of early gravity and seismic surveys suggests that the Mono Basin is a shallow structure resulting from regional warping and faulting with a depth of 1 - 1.5 km (Christensen and others, 1969) or 2-2.5 km (Pakiser, 1976). Christensen and others (1969) suggested that steep gravity gradients within Mono Basin are due to facies changes in the basin fill, faults buried within the basin, or density contrasts between lacustrine silts, marginal gravels and sands, and volcanic breccias. The deepest part of the basin is near the foot of the Sierra Nevada escarpment, towards the west. The density contrast between pre-Cenozoic metamorphic and granitic basement rocks is thought to be approximately $150 \mathrm{~kg} / \mathrm{m}^{3}$. Work by Pakiser (1976) indicates that a large gravity low ( 50 mGal) covers the area of Mono Lake and reflects primarily low-density lacustrine sediments. 


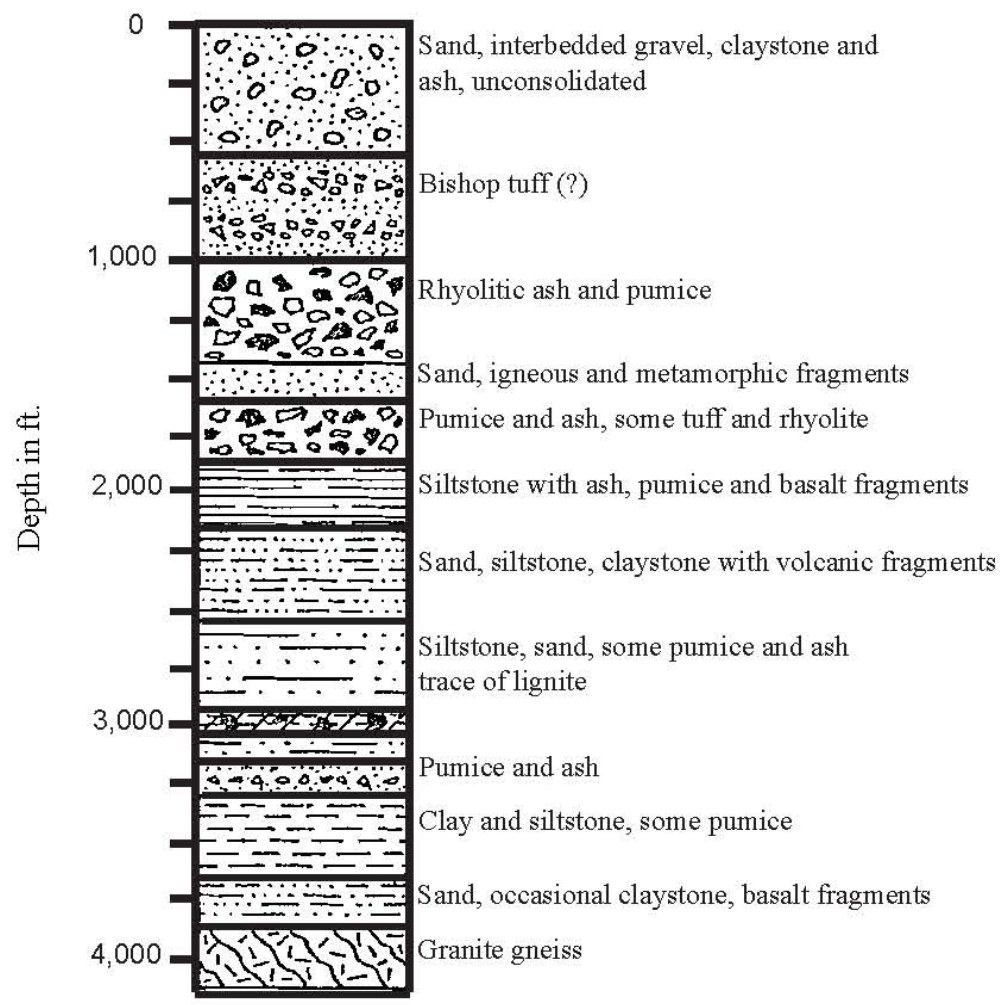

Figure 5a. Lithologic column of geothermal state well "State PRC 4397.1" modified from Axtell (1972). See Fig. 1 for location.

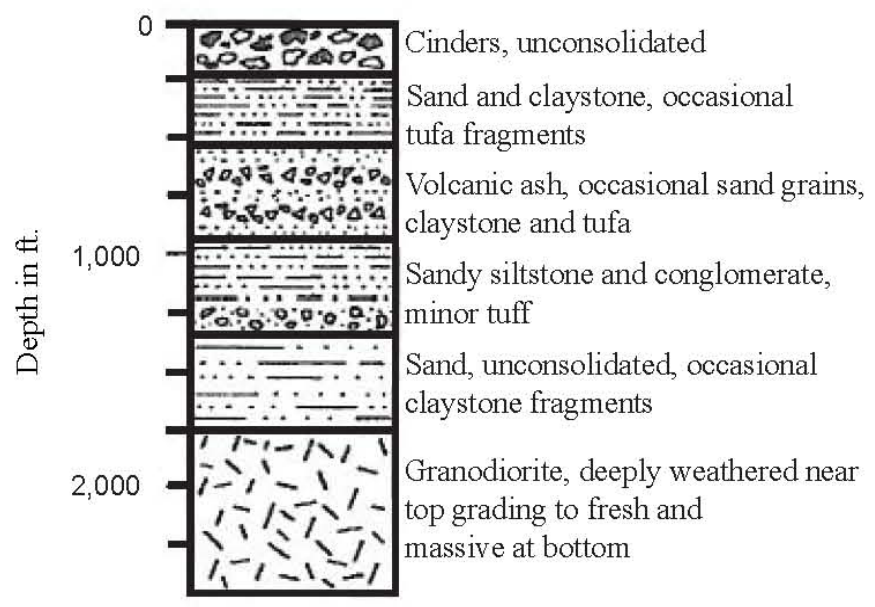

Figure 5b. Lithologic column of geothermal state well “State PRC 4572.1” modified from Axtell (1972). See Fig. 1 for location. 
In an attempt to delineate the depth and geometry of a magmatic source for the Mono Domes, seismic and magnetotelluric studies were conducted. Hill and others (1985) performed a seismic refraction study which was used to: (1) evaluate the structure of the Mono-Inyo volcanic chain as a possible site for deep scientific drilling, (2) assess the possibility that a youthful magma chamber may exist in the upper crust beneath the chain, and (3) look for evidence of feeder dikes for the Mono Domes (Fig. 6a and 6b). Results from their work indicate that any large magma body would have to be at least 7 km beneath the surface. Hermance and others (1984) conducted a magnetotelluric study in Pumice Valley, adjacent to the Mono Domes. Their data did not indicate an observable decrease in resistivity at depths in the upper $10 \mathrm{~km}$ of crust beneath the valley, suggesting that the parent magma body feeding Mono Domes is either too thin or too deep (>10 km) to be resolved. However, an inversion of the travel-time residuals from 94 teleseismic events in 1986 revealed a 200-600 km³ anomalous volume directly beneath the Mono Domes with at least 7\% low velocity, and with a top 8 - $10 \mathrm{~km}$ deep (Achauer and others, 1986). This could be interpreted as a silicic melt or partial melt and in some measure may be controlled by the Sierran frontal fault zone (Achauer and others, 1986). 


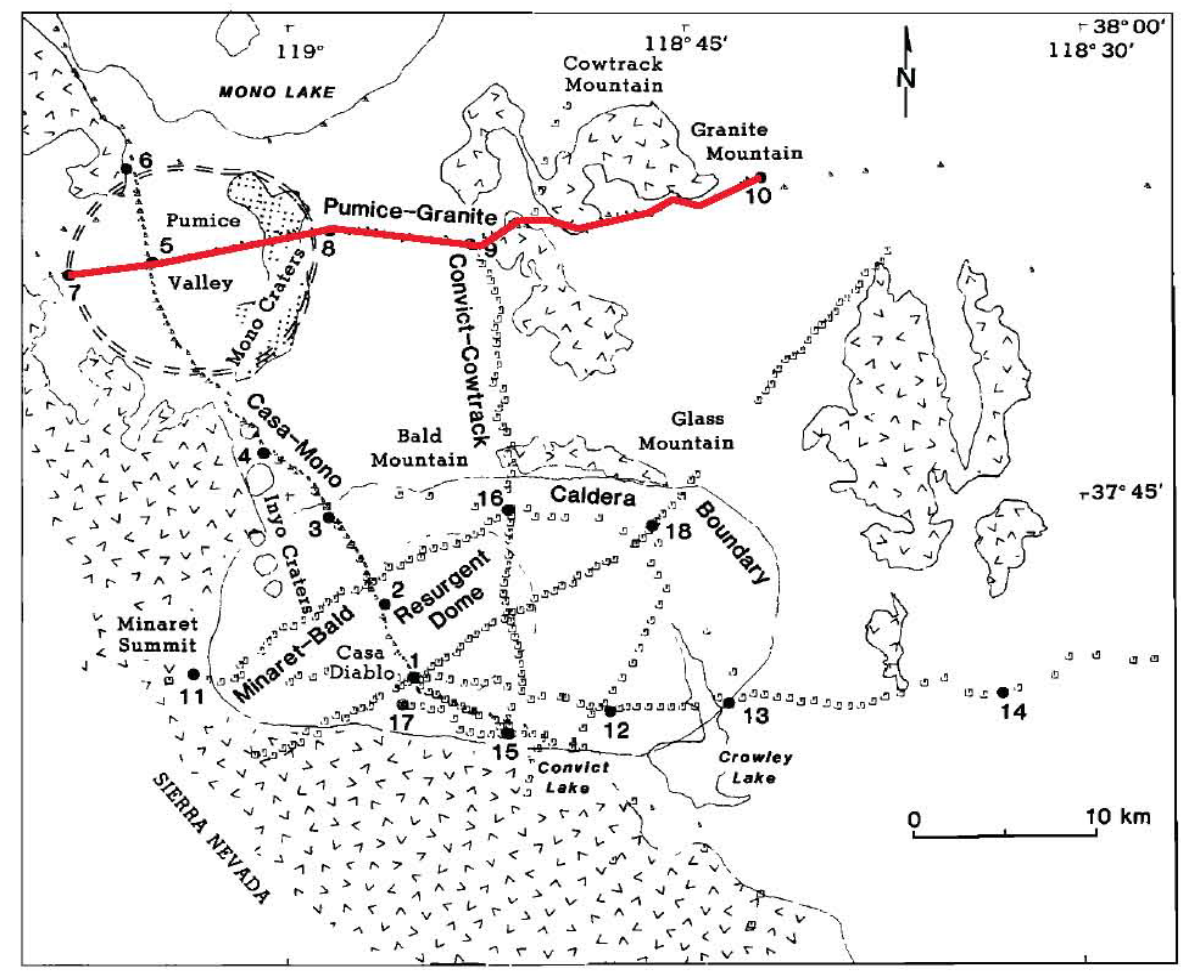

Figure 6a. Index map of seismic refraction surveys modified from Hill et al, (1985). Seismic refraction survey locations are indicated by open circles. The location of the seismic refraction survey referred to in this work is shown by the red line. The seismic model produced from this survey is shown below on Figure $6 b$.
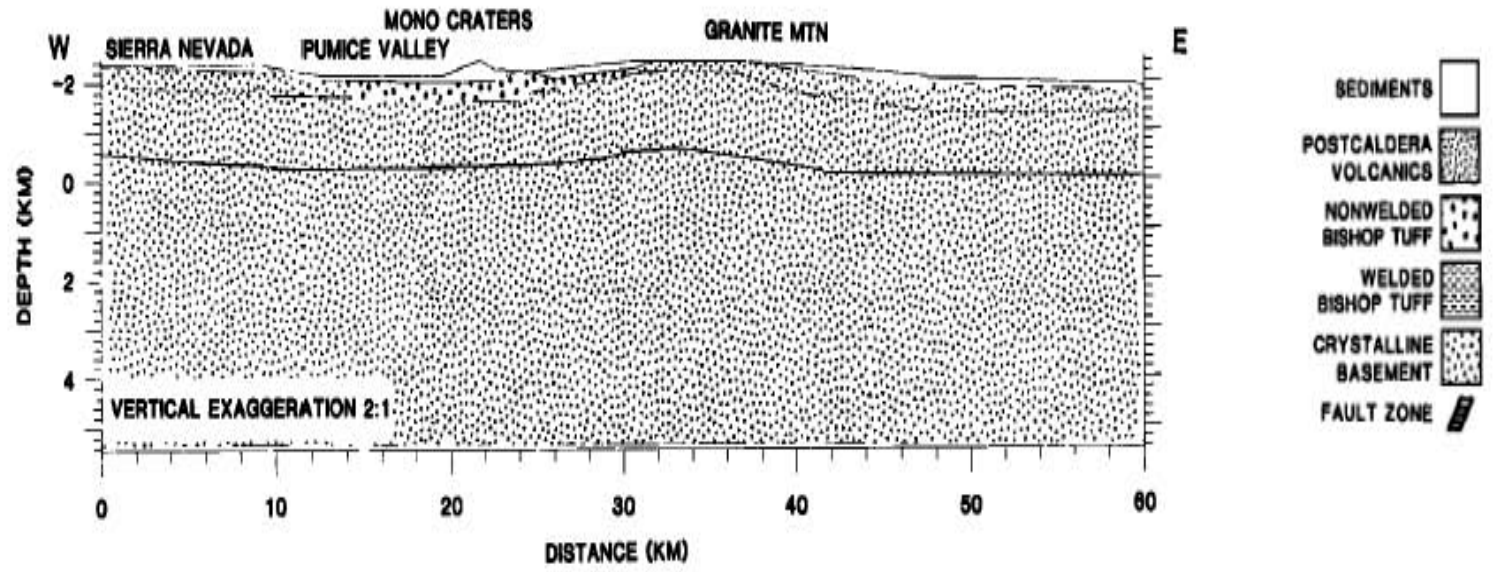

Figure 6b. Seismic refraction model from Hill et al. (1985) of the PumiceGranite line. 
Geologic studies of deformation and faulting along the Sierra Nevada front (Kistler, 1966) suggest a ring fracture is located on the border of a subcircular mylonitized Creatacous pluton. The ring fracture was mapped by tracing exposed mylonitic shear zones around a pluton of hornblende-bearing quartz monzonite near Grant Lake and extrapolating the trend to the south to join the southern arc of the Mono Domes. This trace was linked with a mapped normal fault of the Sierran frontal fault system to the north to complete the ring-fracture (Fig. 7). 


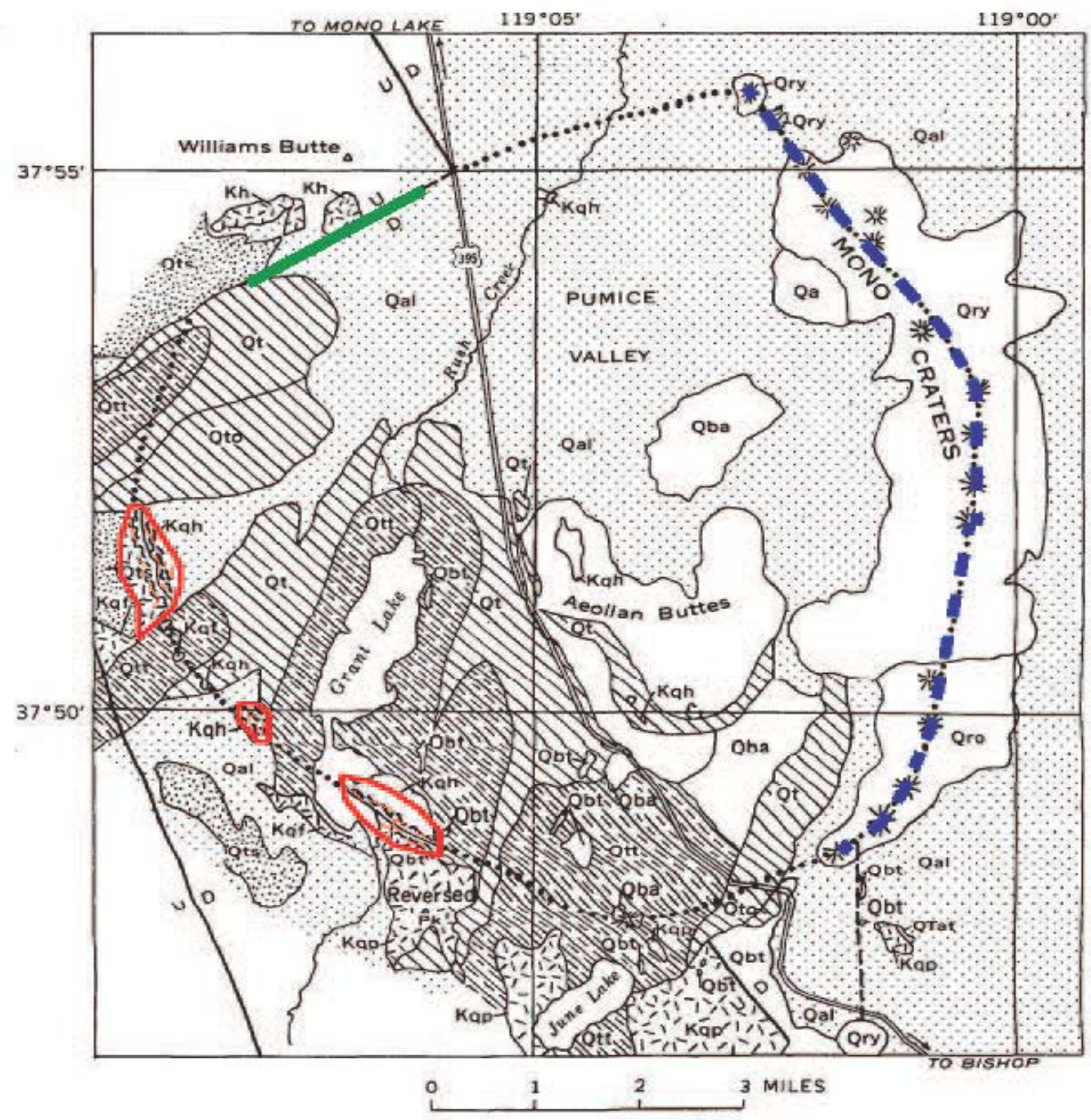

Figure 7. Modified geologic map from Kistler (1966). The ring fracture is shown by the dotted black line. Areas outlined in red show where mylonitic shear zones are exposed at the surface. The solid green line shows a mapped normal fault of sierra frontal fault system. The ring fracture was mapped by joining the axis of Mono Domes (or Mono Craters as labeled on map) with the exposed mylonitic zones and mapped normal fault south of Williams Butte. 


\section{GEOPHYSICAL DATA COLLECTION}

\section{Gravity Data}

Previous gravity stations are within the Mono Basin, but most of the coverage is in and around the Long Valley Caldera. In order to improve the gravity coverage throughout the basin, additional gravity stations were collected in and around the Mono Domes. Approximately 320 gravity stations were collected in the Mono Basin during June and August of 2010 (Fig. 8). These include 51 closely spaced gravity stations at 400-800 m intervals along the seismic line occupied by Hill and others (1985).

Additional gravity stations were collected at $800 \mathrm{~m}$ spacing along existing and unnamed roads within the Mono Basin. GPS data were collected at every gravity station using a handheld Trimble GeoXH, which provides vertical decimeter accuracy. A new gravity base station named LEEVIN was created at the Lee Vining Post Office (Appendix A). LEEVIN was tied to an existing high-precision gravity station located near Toms's Place, south of the Long Valley Caldera (MLEBQ1, Appendix A). LEEVIN was created to place a base station near the field operations to reduce time-dependent linear drift of the gravity meter. All gravity data are tied to the base station LEEVIN.

The LaCoste \& Romberg gravity meter G614 and Scintrex gravity meter CG5A were used in this survey. Conversion of meter readings to gravity units for G614 and CG5A were made using factory calibration constants as well as a secondary calibration factor (1.00036 for G614 and 1.00630 for CG5A). These were determined by multiple gravity readings over the Mt. Hamilton calibration loop east of San Jose, California 
(Barnes and others, 1969). Gravity data collected during the summer of 2010 were processed using standard gravity methods (e.g. Blakely, 1995) which are outlined in the geophysical data processing section.

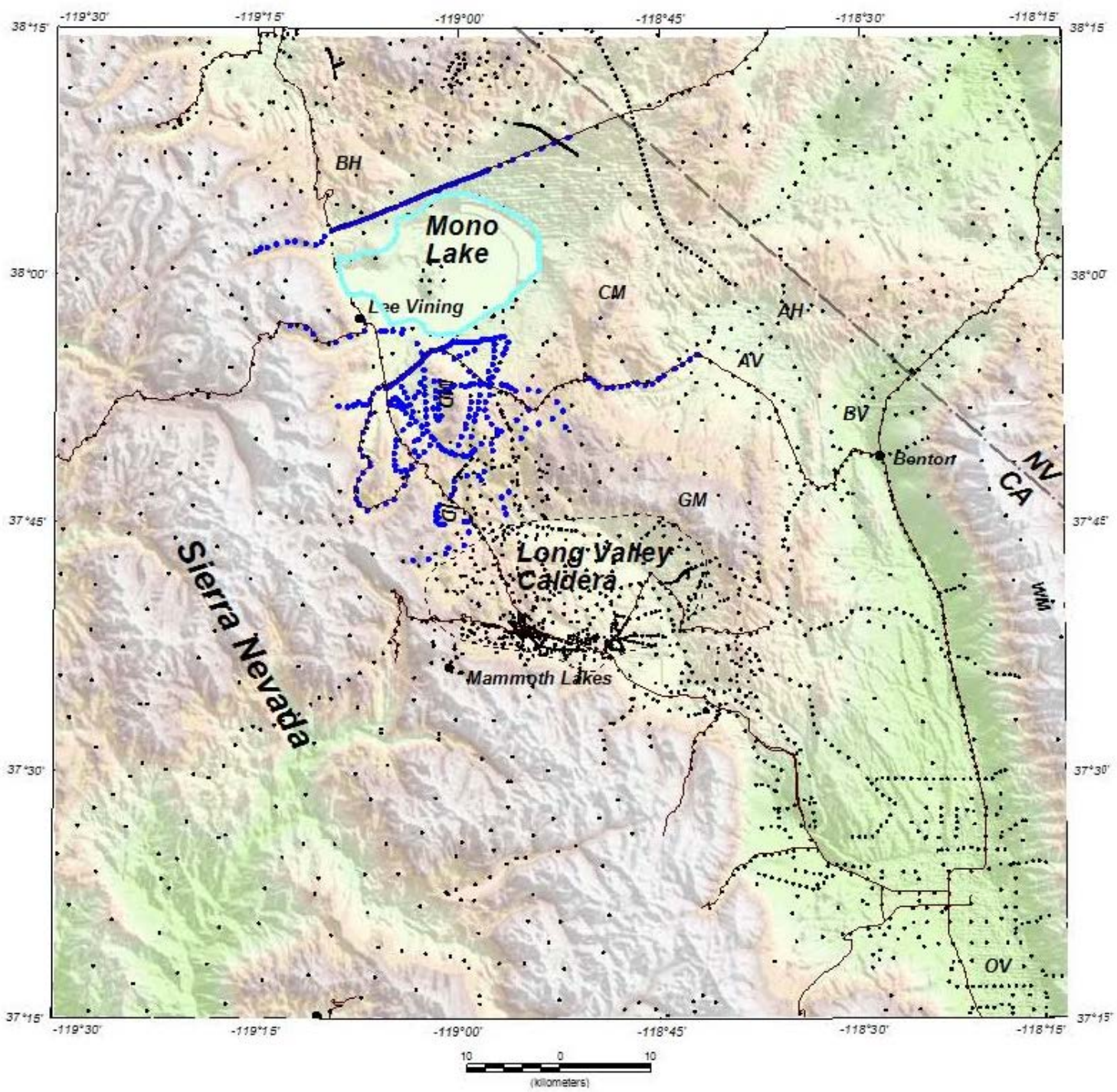

Figure 8. Map of gravity station locations throughout the Mono Basin study area. Blue dots show location of gravity stations collected during the summer of 2010. Black dots show locations of pre-existing gravity stations (Battaglia et al., 2003). 


\section{Magnetic Data}

Aeromagnetic data used for this study are from a statewide compilation of California (Roberts and Jachens, 1999) and displayed as a color-contoured map (Table 1;

Fig. 9 and 10). The regional aeromagnetic compilation consists of several surveys flown between 9,000 and 13,500 barometric elevation with flight lines oriented east-west and spaced $0.8 \mathrm{~km}$ to $1.6 \mathrm{~km}$ apart (Fig. 9). An International Geomagnetic Reference Field (IGRF), updated to the flight date of the individual surveys, was removed from each survey. Each survey was gridded at 1-km spacing and either upward or downward continued to a common datum of $305 \mathrm{~m}$ above the ground surface. A minimum curvature algorithm was used to grid each survey and grids were merged together into a final map.

Because the majority of the aeromagnetic data has poor resolution, additional ground magnetic data were necessary to better constrain magnetic anomalies throughout the basin, especially around the Mono Domes. Approximately 289 line-km of trucktowed magnetometer data were collected along numerous traverses throughout the Mono Basin (Fig. 11). Magnetic data were collected at one-second intervals using a Geometrics G858 cesium vapor magnetometer attached to an aluminum carriage. The carriage was connected to a vehicle by aluminum tubing and towed approximately $9 \mathrm{~m}$ behind the vehicle. The magnetometer was towed behind the vehicle to minimize any magnetic signal the vehicle may have, and it was positioned $2 \mathrm{~m}$ above ground surface. Trucktowed magnetic data were recorded and viewed in real-time using Geometrics MagLog software during field operations. The location of the magnetometer was recorded using a 
Trimble nonmagnetic Ag132 GPS receiver mounted on the aluminum frame attached to the magnetometer. The Ag132 receiver has real-time differential correction capabilities using an Omnistar satellite system, resulting in submeter horizontal accuracy. Raw magnetic data were downloaded and processed using Geometrics MagMap 2000 software, where magnetometer and GPS data were merged.

Table 1. Aeromagnetic survey specification. See Figure 9 for survey boundaries. Numbers in parentheses are index numbers from the references publication (Roberts and Jachens, 1999). D, drape (above ground); B, barometric elevation

\begin{tabular}{|c|c|c|c|c|c|}
\hline $\begin{array}{l}\text { Index } \\
\text { ID }\end{array}$ & Name & $\begin{array}{c}\text { Date } \\
\text { Flown }\end{array}$ & $\begin{array}{c}\text { Flight } \\
\text { line } \\
\text { (mi) }\end{array}$ & $\begin{array}{l}\text { Flight } \\
\text { Dir. }\end{array}$ & Altitude (ft) \\
\hline $\begin{array}{c}\text { A } \\
(3134)\end{array}$ & $\begin{array}{c}\text { Hoover-Walker } \\
\text { Lake }\end{array}$ & 1978 & $0.5-1$ & E-W & $1,000 \mathrm{D}$ \\
\hline $\begin{array}{c}\mathrm{B} \\
(3002 \mathrm{C}) \\
\end{array}$ & $\begin{array}{c}\text { Western Nevada - } \\
\text { Aurora } \\
\end{array}$ & 1967 & 1 & E-W & $11,000 \mathrm{~B}$ \\
\hline $\begin{array}{c}\mathrm{C} \\
(4233)\end{array}$ & Bodie-Aurora & 1999 & 0.093 & $\mathrm{~N}-\mathrm{S}$ & $500 \mathrm{D}$ \\
\hline $\begin{array}{c}\mathrm{D} \\
(4253)\end{array}$ & Excelsior Mountains & $\begin{array}{l}2000- \\
2001\end{array}$ & 0.155 & N-S & $820 \mathrm{D}$ \\
\hline $\begin{array}{c}E \\
(3002 A)\end{array}$ & Western Nevada & 1967 & 1 & E-W & $9000 \mathrm{~B}$ \\
\hline $\begin{array}{c}F \\
(4010) \\
\end{array}$ & Tioga Lake & 1980 & 0.5 & $\begin{array}{l}\text { NE- } \\
\text { SW }\end{array}$ & $1,000 \mathrm{D}$ \\
\hline $\begin{array}{c}G \\
(4058 B)\end{array}$ & $\begin{array}{l}\text { White \& Inyo } \\
\text { Mountains B }\end{array}$ & 1981 & 0.5 & E-W & $8,000 \mathrm{~B}$ \\
\hline $\begin{array}{c}\mathrm{H} \\
(3027)\end{array}$ & Eastern California & 1973 & 1 & E-W & $13,500 \mathrm{~B}$ \\
\hline $\begin{array}{c}\mathrm{I} \\
(0242)\end{array}$ & Long Valley ‘56 & 1956 & 1 & E-W & $9,000 \mathrm{~B}$ \\
\hline $\begin{array}{c}\mathrm{J} \\
(4058 \mathrm{~A})\end{array}$ & $\begin{array}{l}\text { White \& Inyo } \\
\text { Mountains A }\end{array}$ & 1981 & 0.5 & E-W & $14,500 \mathrm{~B}$ \\
\hline $\begin{array}{c}\mathrm{K} \\
(3135) \\
\end{array}$ & Devils Postpile & 1978 & 0.5 & E-W & $1,000 \mathrm{D}$ \\
\hline $\mathrm{L}$ & Mariposa & 1979 & 3 & E-W & $400 \mathrm{D}$ \\
\hline $\begin{array}{c}\mathrm{M} \\
(4058 \mathrm{C})\end{array}$ & $\begin{array}{l}\text { White \& Inyo } \\
\text { Mountains C }\end{array}$ & 1981 & 0.5 & E-W & $7,000 \mathrm{~B}$ \\
\hline
\end{tabular}




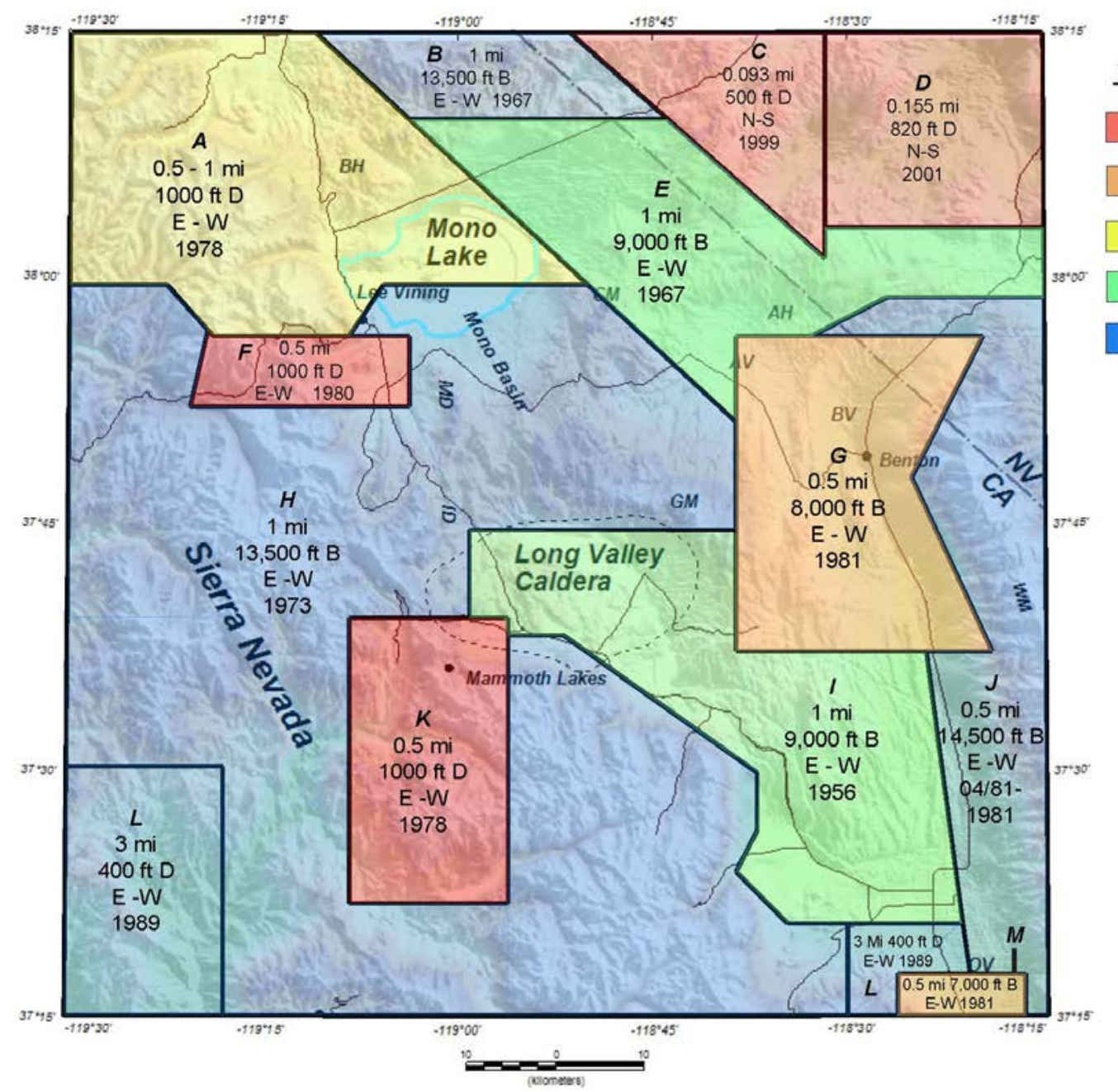

Flight-line spacing $(\mathrm{km})$, flight elevation $(\mathrm{m})$

$0.805 \mathrm{~km}, 152.4-304.8 \mathrm{~m}$ drape

$\square 0.805 \mathrm{~km}, 213.4-2438.4 \mathrm{~m}$ barometric

$0.805-1.609 \mathrm{~km}, 304.8 \mathrm{~m}$ drape

$1.609 \mathrm{~km}, 2743.2 \mathrm{~m}$ barometric

0.805 - $4.825 \mathrm{~km}$

$121.9 \mathrm{~m}$ drape $-4419.6 \mathrm{~m}$ barometric

Figure 9. Aeromagnetic survey flight-line specifications, B, barometric; D, drape. 


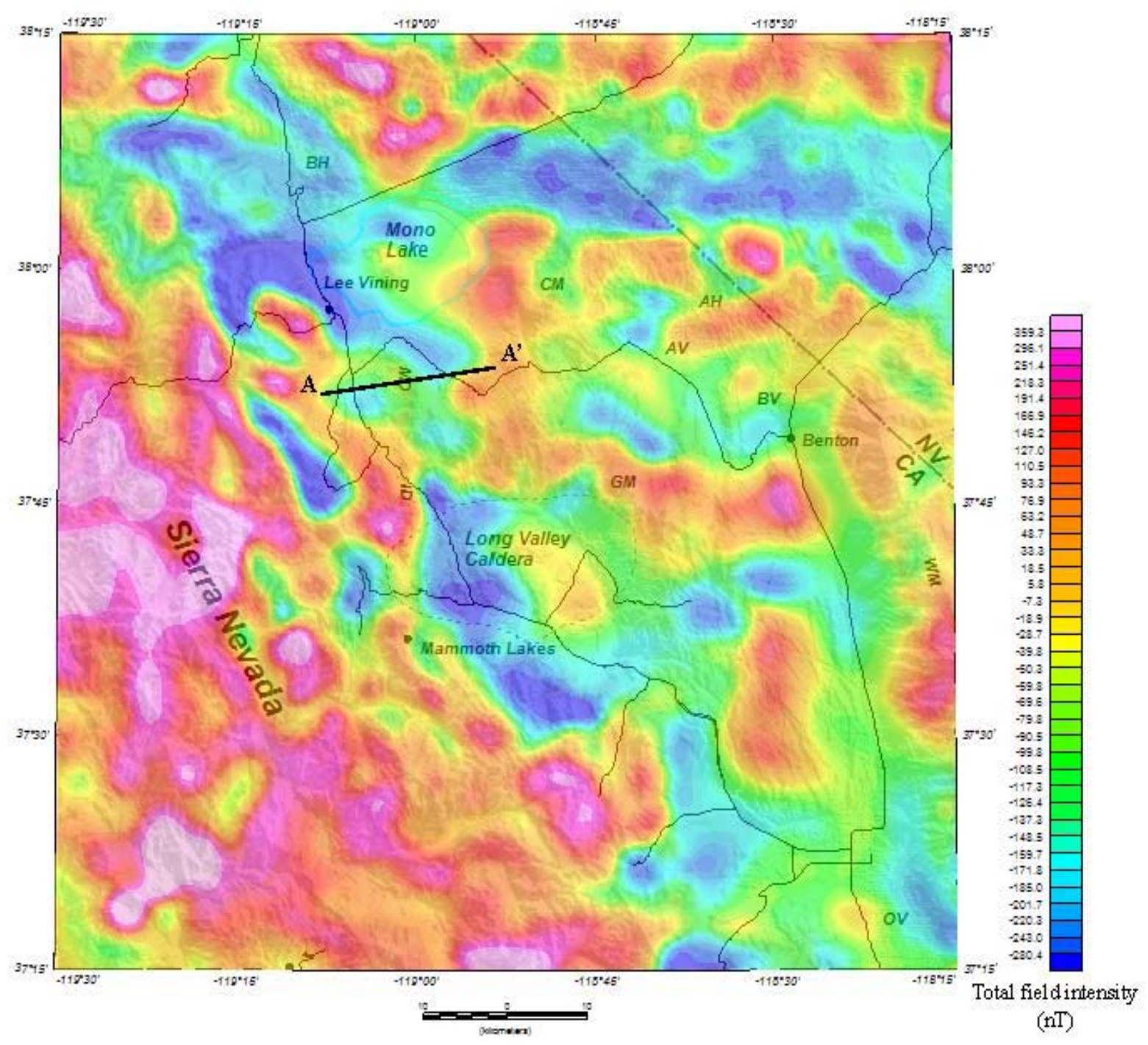

Figure 10. Regional aeromagnetic anomaly map of the Mono Basin study area. Black line shows location of profile A-A'. 


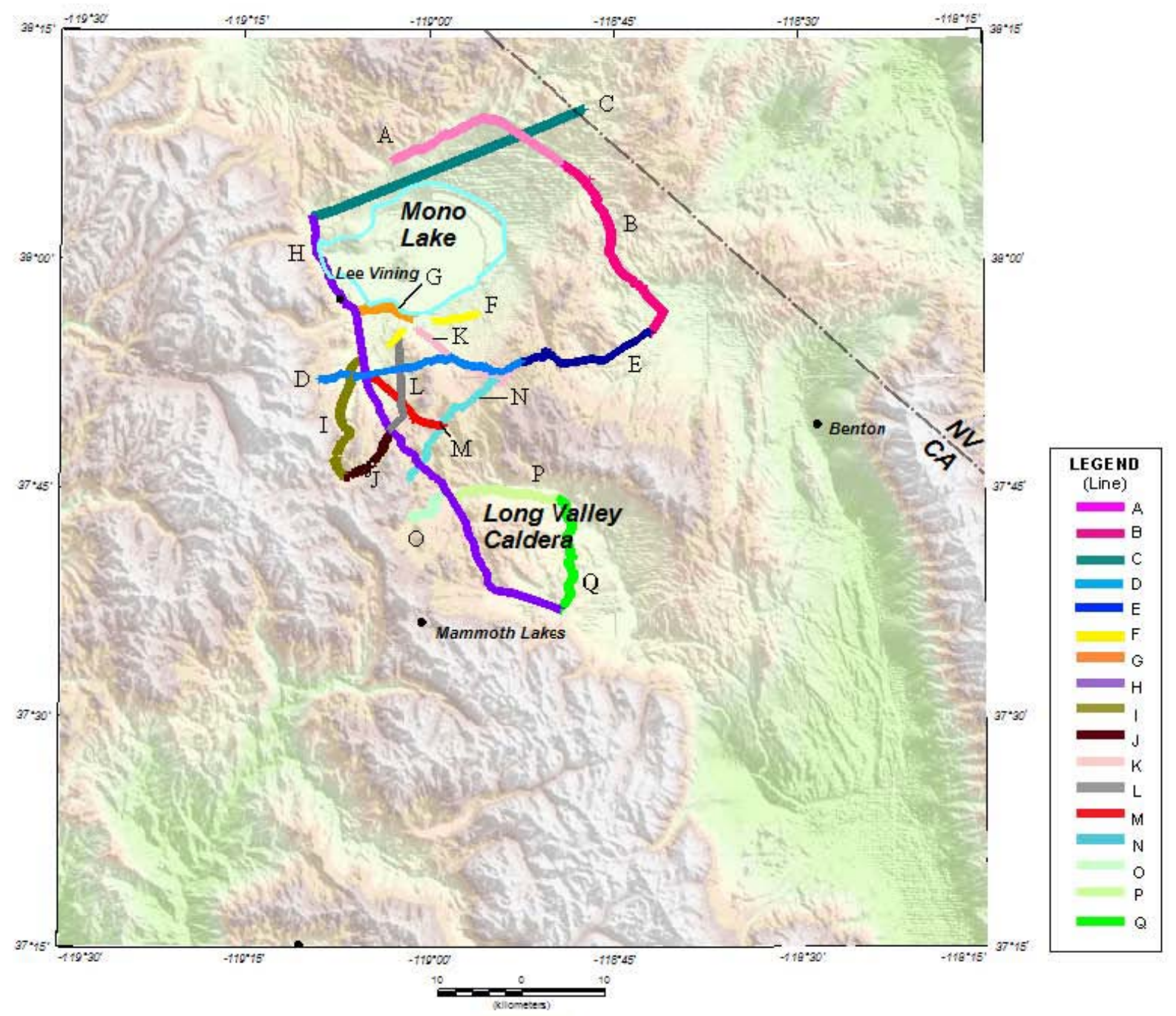

Figure 11. Location of truck-towed magnetometer and ground magnetic (Line D) traverses.

Approximately 8 line-km of ground magnetic data were collected along a traverse across the Mono Domes (Fig. 11, Line D). This traverse was collected using a Geometrics G858 cesium vapor magnetometer with the same survey and GPS specifications as the truck- 
towed magnetometer surveys. The magnetometer height above the ground surface was approximately $2 \mathrm{~m}$.

A portable Geometrics G856 proton-precession base-station magnetometer was used to record diurnal variations of the Earth's magnetic field during the truck-towed and ground magnetic surveys. The diurnal variations are known to be larger in the summer than in winter and the amplitudes can span tens of nanoteslas. These variations are believed to be caused by electric currents induced in the Earth from electric currents in the ionosphere which are in turn driven by solar activity.

\section{Physical Property Data}

Rock samples were collected throughout the study area to measure density and magnetic susceptibility. This information is necessary for geophysical modeling to constrain the physical properties of geologic units used. Rock samples were collected at newly acquired gravity stations when a rock outcrop was nearby and at other locations throughout the basin (Fig. 12). Densities and magnetic susceptibilities were averaged by rock type (Table 2). Physical properties of individual rock samples collected in the field are presented in Appendix B. Densities were measured using the buoyancy method with an electronic balance, and a Kappameter ${ }^{\circledR}$ KT-5 was used to measure magnetic susceptibility. Grain, saturated-bulk, and dry-bulk densities were calculated for each sample by weighing the sample in air (Wa), saturated and submerged in water $(W w)$, and weighed in air and saturated (Was) using the following formulas (all weights are measured in grams):

$$
\text { Grain density }=1,000 \mathrm{~kg} / \mathrm{m}^{3} * W a /(W a-W w) \text {, }
$$


Saturated-bulk density $=1,000 \mathrm{~kg} / \mathrm{m}^{3} *$ Was $/($ Was $-W w)$,

Dry-bulk density $=1,000 \mathrm{~kg} / \mathrm{m}^{3} * W a /($ Was-Ww $)$

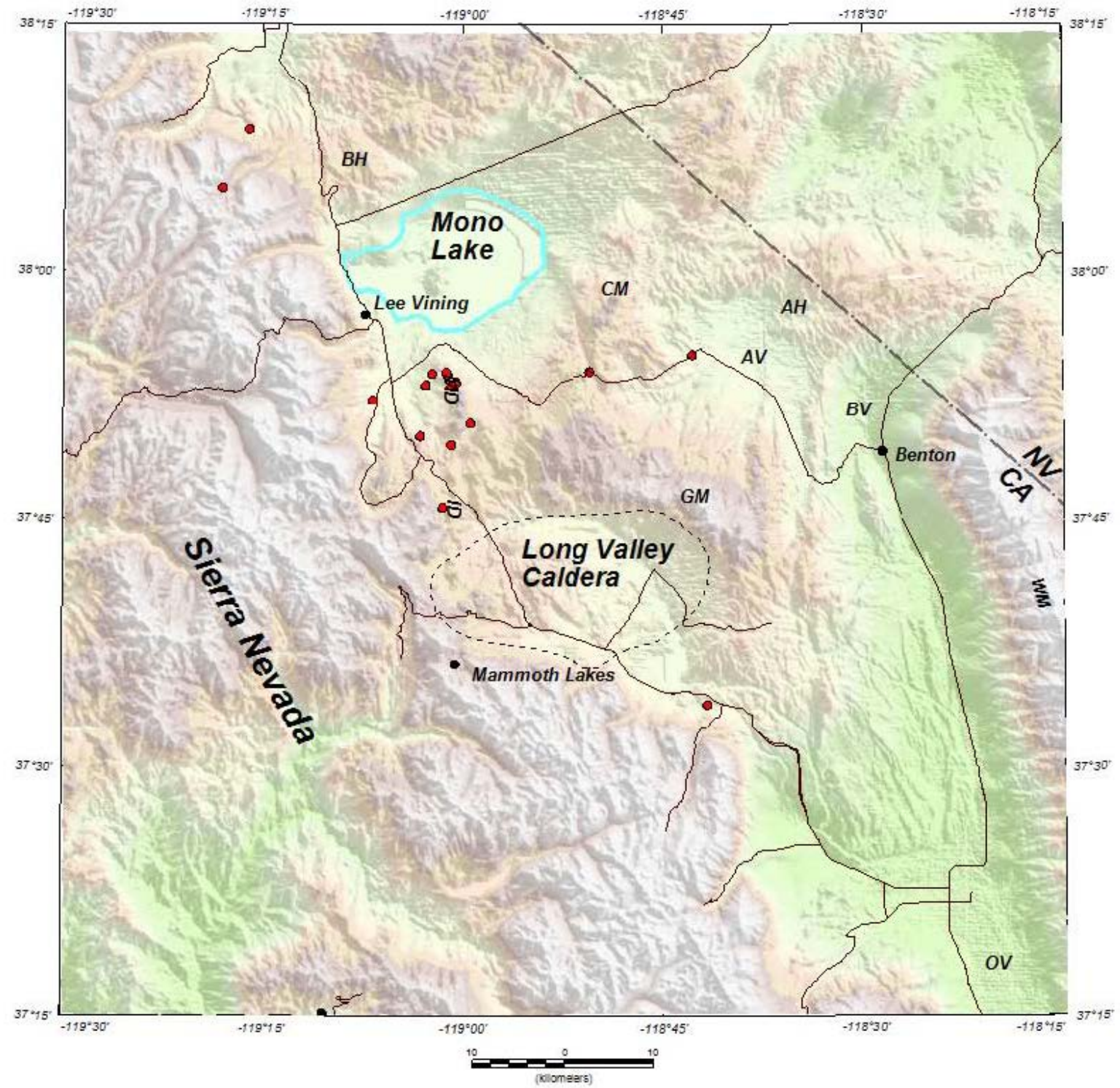

Figure 12. Location map of rock samples collected in 2010. 
Table 2. Physical property measurements of selected rock types collected in 2010. GD, grain density; SBD, saturated bulk density; DBD, dry bulk density; Susc, magnetic susceptibility

\begin{tabular}{|l|c|c|c|c|c|}
\hline \multicolumn{1}{|c|}{ Rock Type } & $\begin{array}{c}\text { No. of } \\
\text { samples }\end{array}$ & $\begin{array}{c}\text { GD } \\
\left(\mathbf{k g} / \mathbf{m}^{3}\right)\end{array}$ & $\begin{array}{c}\text { SBD } \\
\left(\mathbf{k g} / \mathbf{m}^{3} \mathbf{)}\right.\end{array}$ & $\begin{array}{c}\text { DBD } \\
\left(\mathbf{k g} / \mathbf{m}^{3} \mathbf{)}\right.\end{array}$ & $\begin{array}{c}\text { Susc. } \\
\left(\mathbf{1 0}^{-3} \mathbf{S I}\right)\end{array}$ \\
\hline Basalt & 5 & 2557 & 2441 & 2363 & 13.476 \\
\hline Granite & 8 & 2672 & 2615 & 2581 & 5.541 \\
\hline Granodiorite & 3 & 2684 & 1983 & 2629 & 13.207 \\
\hline Metasediment & 1 & 2675 & 2651 & 2636 & 0.03 \\
\hline Obsidian & 9 & 2018 & 199 & 1975 & 0.779 \\
\hline Rhyolite & 16 & 1872 & 1813 & 173 & 1.624 \\
\hline BishopTuff & 6 & 1935 & 1687 & 1419 & 2.458 \\
\hline
\end{tabular}

\section{GEOPHYSICAL DATA PROCESSING}

\section{Gravity Methods}

A new color-contoured, isostatic gravity anomaly map of the study area was produced using over 2,700 stations (Fig. 13). This dataset includes the gravity stations collected during the 2010 summer field season and an existing gravity dataset (Battaglia et al., 2003). The isostatic gravity anomaly map shows lateral variation in the density of subsurface rocks. Gravity values are given in milligals (mGal), a unit of acceleration or gravitational force equal to $10^{-5} \mathrm{~m} / \mathrm{s}^{2}$. Observed gravity readings were referenced to the International Gravity Standardization Net 1971 (IGSN 71) gravity datum (Morelli, 1974). 


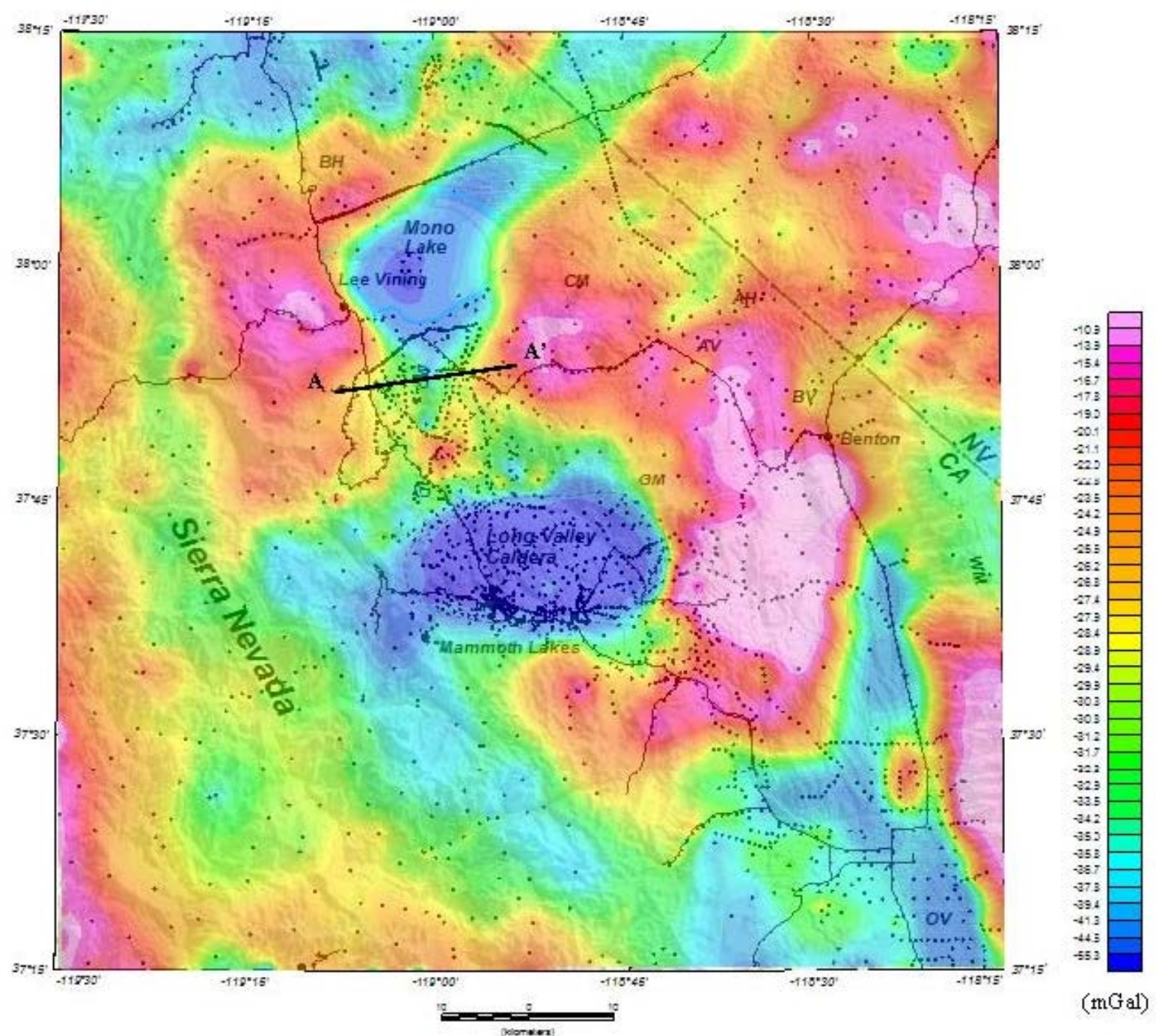

Figure 13. Isostatic gravity anomaly map of the Mono Basin study area. Grey dots represent gravity station locations. The black line shows the location of profile A-A'.

The following corrections were applied to the 2010 gravity data before they were merged in to the existing gravity dataset. Gravity data from 2010 is presented in Appendix C.

The instrument-drift correction accounts for the changes in the gravimeter spring over time or due to temperature changes. The instrument drift is addressed by re-occupying a 
gravity base station at the beginning and end of each day and applying a linear timedependent drift correction to all other measurements.

The earth-tide correction accounts for the gravitational pull of the moon and sun, which are dependent upon time and latitude. Although these effects are small, they are significant enough to be detected by a gravimeter. The change in gravity due to this phenomenon does not exceed $0.3 \mathrm{mGal}$.

The latitude correction removes the variation in the Earth's gravity with latitude, which is caused by the centrifugal force of the rotation of the earth along with the resulting bulge at the equator. This correction is accounted for in the theoretical gravity equation.

Theoretical gravity at sea level is given by the equation

$$
g_{t}=(978,031.85)\left(1+0.005278895 \sin ^{2} \phi+0.000023462 \sin ^{4} \phi \mathrm{mGal}\right.
$$

where $\phi$ is latitude in degrees.

The free-air correction is applied to remove the variation in gravity due to changes in the gravity station's elevation relative to sea level. The free-air correction does not include the gravitational effect of the material between the station and sea level. The free-air correction was calculated using Swick’s (1942) formula:

$$
\begin{aligned}
& \text { fac }=h(0.30877+\sigma(-0.0013398+\sigma(-0.0005329+\sigma(0.0000911))) \\
& -h\left(0.072 \times 10^{-6}\right),
\end{aligned}
$$


where $\sigma=0.0001 \phi^{2}$ and $h$ is the elevation of the station in meters and is positive if above sea level.

The free-air anomaly is the difference between the observed gravity and the theoretical gravity at the elevation and latitude of the measurement. The free-air anomaly was calculated using the Geodetic Reference System 1967 formula for theoretical gravity on the ellipsoid (International Union of Geodesy and Geophysics, 1971) and is given by the equation:

$$
\text { faa }=\left(g_{o}-g_{t}\right)+\text { fac }
$$

where $g_{o}$ is the observed gravity.

The Bouguer correction corrects for the excess mass between the station and sea level. In our case, we assumes the material between sea level and the gravity station is an infinite slab of uniform density of $2670 \mathrm{~kg} / \mathrm{m}^{3}$. The Bouguer correction equation is given by:

$$
\mathrm{bc}=-0.111897 \mathrm{~h}
$$

where $h$ is the elevation of station in meters and is postive if above sea level.

The terrain correction removes the gravitational effect of topography to a radial distance of $167 \mathrm{~km}$ around the gravity station and was computed using both manual and digital methods. Three types of terrain corrections were applied: innermost or field terrain, innerzone-terrain, and outerzone-terrain. The innermost-terrain corrections were estimated in the field and extend from the station to a radial distance of $68 \mathrm{~m}$, equivalent to Hayford and Bowie’s (1912) zone B. Inner zone-terrain corrections were estimated from Digital 
Elevation Models (DEMs) with 10 or 30-m resolutions derived from USGS 7.5' topographic maps and extend from $68 \mathrm{~m}$ to a radial distance of $2 \mathrm{~km}$ (D. Plouff, USGS, unpub. software, 2010). Outerzone-terrain corrections, from $2 \mathrm{~km}$ to a radial distance of $167 \mathrm{~km}$, were computed using a DEM derived from USGS 1:250,000-scale topographic maps using an automated procedure based on geographic coordinates (Plouff, 1966; Plouff, 1977; Godson and Plouff, 1988). Digital-terrain corrections were calculated by computing the gravity effect of each grid cell in the DEM using the distance and difference in elevation of each grid cell from the gravity station.

The curvature correction accounts for the effect of the Earth's curvature. The curvature correction was calculated using the following equation (Plouff, 1977):

$$
\mathrm{cc}=h\left(0.001464+h\left(4.5 \times 10^{-14}-3.533 \times 10^{-7}\right)\right)
$$

where $\mathrm{h}$ is the elevation in meters and is positive if above sea level.

The complete Bouguer anomaly combines the free-air anomaly, bouguer, terrain, and curvature corrections and is given by the equation:

$$
\mathrm{cba}=\mathrm{faa}+\mathrm{bc}+\mathrm{tc}-\mathrm{cc}
$$

where tc is the terrain correction.

The isostatic correction removes long-wavelength differences in the gravity field related to the compensation of topographic loads. A regional isostatic gravity field was removed from the complete Bouguer anomaly assuming an Airy-Heiskanen model for isostatic compensation of topographic loads (Jachens and Roberts, 1981) with an assumed 
sea-level crustal thickness of $25 \mathrm{~km}$, a crustal density of 2,670 kg/m³, and a density contrast across the base of the crust of $400 \mathrm{~kg} / \mathrm{m}^{3}$.

\section{Magnetic Methods}

Diurnal variations recorded by the base-station magnetometer were removed from the truck-towed and ground magnetic datasets. Both datasets were filtered using a low pass filter to remove anomalous high and low spikes caused by cultural "noise,” such as passing cars, culverts, fences, and powerlines. The cut-off for the low-pass filter ranged from 10 to 50 wavelengths. A new magnetic anomaly profile map of the study area was produced using the filtered truck-towed and ground magnetic data (Fig. 14). Truck-towed magnetic datasets are presented in Appendix D.

\section{Reduction-To-The-Magnetic Pole}

Magnetic anomalies are frequently laterally shifted from their sources and may have distorted, irregular shapes because of the direction of magnetization rarely in the direction of the Earth's magnetic field. A reduction-to-the-magnetic-pole (RTP) filter changes the Earth's magnetic field inclination to $90^{\circ}$, as if it were at the magnetic pole; results are shown on the resulting map (Fig.15). 


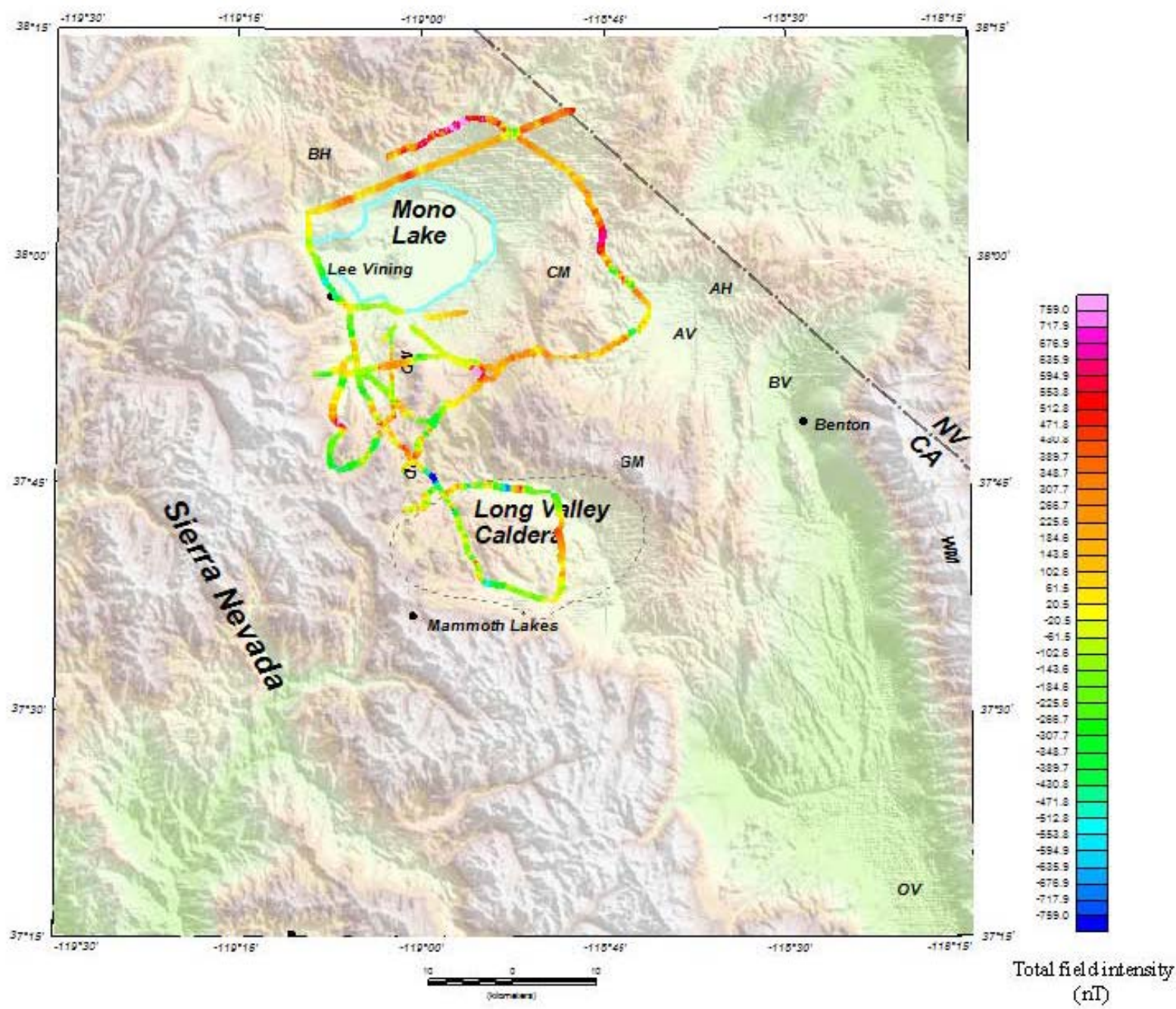

Figure 14. Truck-towed and ground magnetic anomaly map. See Figure 11 for location of truck-towed and ground magnetic surveys. 


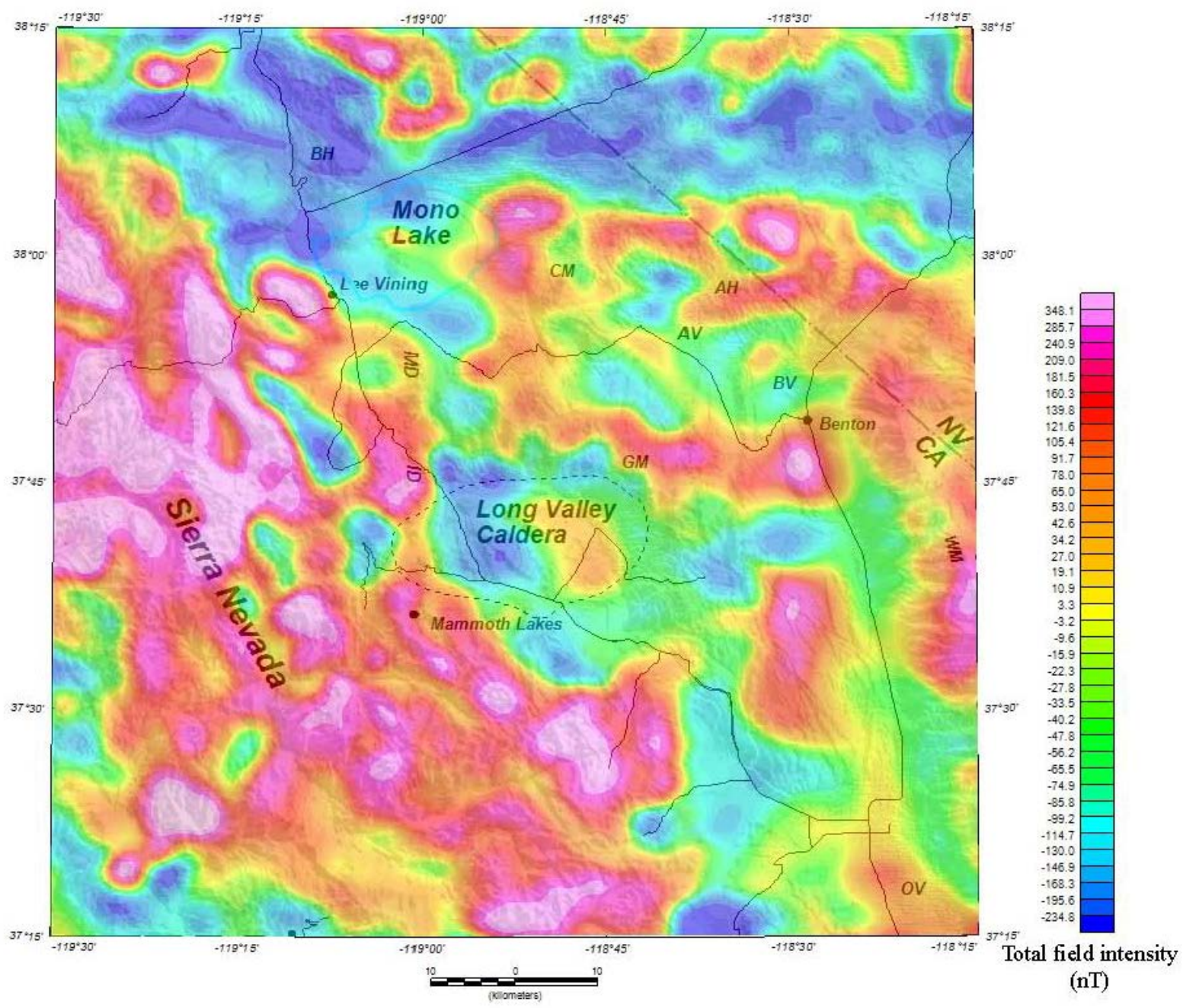

Figure 15. Reduction-to-the-magnetic pole map of the Mono Basin study area.

This procedure aids in the interpretation by creating symmetrical magnetic anomalies that are essentially centered over their sources. This transformation simplifies magnetic anomaly maps and is a fairly easy transformation at high magnetic latitudes (Telford and others, 2004). 


\section{Magnetic-Potential}

A directional derivative links the gravity and magnetic potentials that are caused by a homogeneously dense and magnetized body, allowing the total magnetic field to be transformed into a corresponding gravity field. A magnetic potential map (Fig. 16) is produced by converting the magnetic anomalies to gravity anomalies using Poisson's relation, assuming magnetic and gravity anomalies are created by the same source.

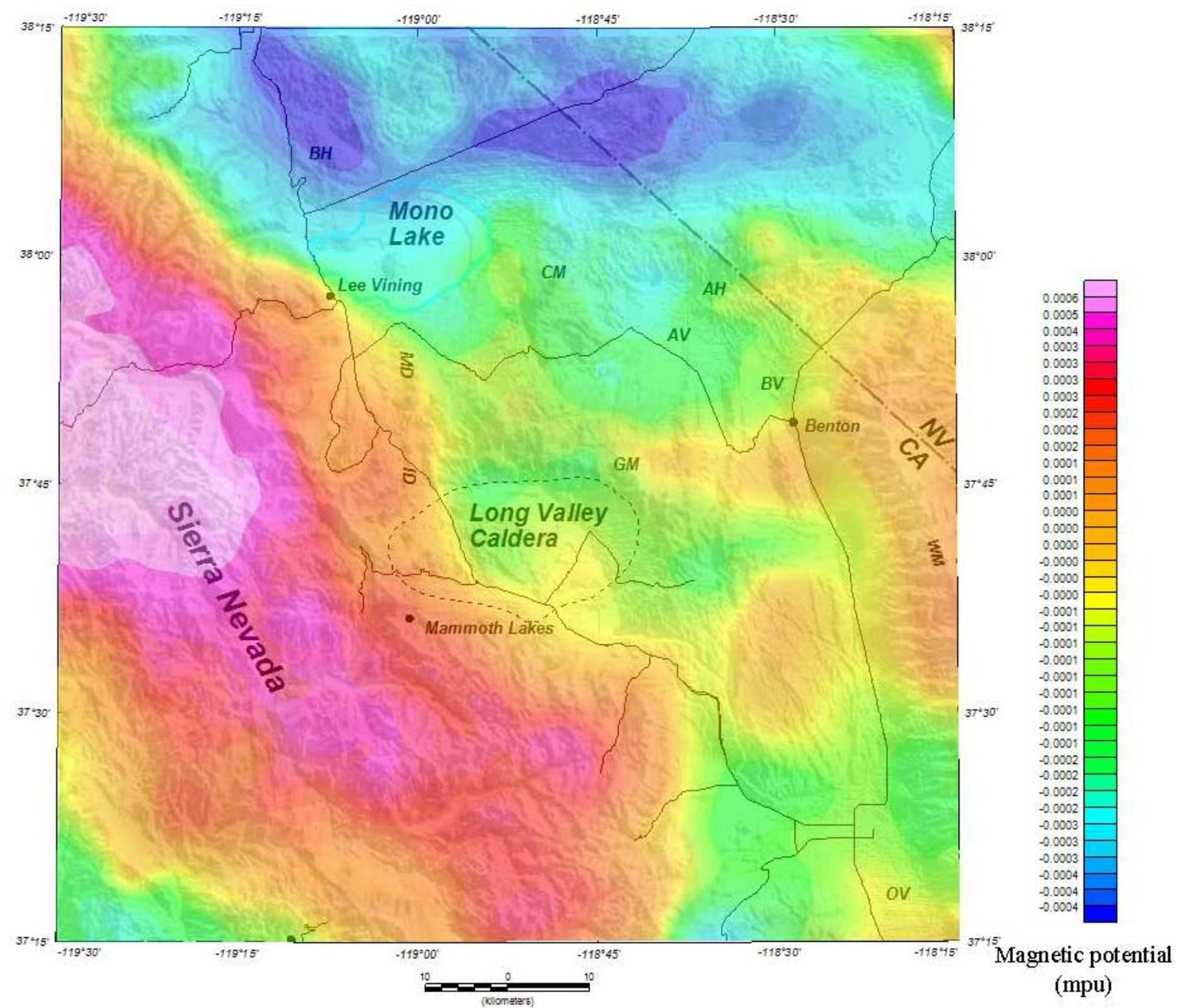

Figure 16. Magnetic potential map of the Mono Basin study area derived from the transformation of magnetic anomalies. mpu, magnetic potential units (dimensionally amperes). 
The ratio between density and magnetization is kept constant. For this work the ratio is a density contrast of $0.10 \mathrm{~g} / \mathrm{cm}^{3}$ to a magnetization contrast of 0.001 cgs units. Magnetic potential transformations are helpful for simplifying the interpretation of magnetic anomalies because magnetic anomalies are more complex than gravity anomalies. Gravity anomalies often have the steepest horizontal gradient roughly over the edges of the causative source. This property can be utilized in magnetic interpretation by transforming the magnetic anomaly to a magnetic potential anomaly and locating the steepest horizontal gradients (Blakely, 1995).

\section{Maximum horizontal gradients}

Maximum horizontal gradients were calculated for gravity and magnetic data to help delineate the edges of potential-field sources. A procedure described by Blakely and Simpson (1986) was used to calculate the maximum horizontal gradients. Maximum horizontal gradients indicate abrupt lateral changes in the density or magnetization of subsurface rocks. Maximum horizontal gradients calculated for the isostatic gravity and magnetic-potential map and are shown on respective maps (Figs. 17 and 18).

\section{Residual anomaly}

The residual anomaly map displays the magnetic anomalies produced by shallow, short-wavelength magnetic sources and removes the effect of the deeper, longer-wavelength anomalies (Fig.19). To produce the residual anomaly map, an upward continuation of the data must be performed. The upward continuation transformation is a filtering process that reduces the intensity of anomalies produced by near-surface sources and enhances the 
anomalies caused by long wavelength, deep sources. An upward continuation filter at a depth of $1 \mathrm{~km}$ was applied to the aeromagnetic anomaly map. The upward continued data was then subtracted from the original aeromagnetic data to produce a residual, or shallow magnetic, anomaly map (Fig. 19).
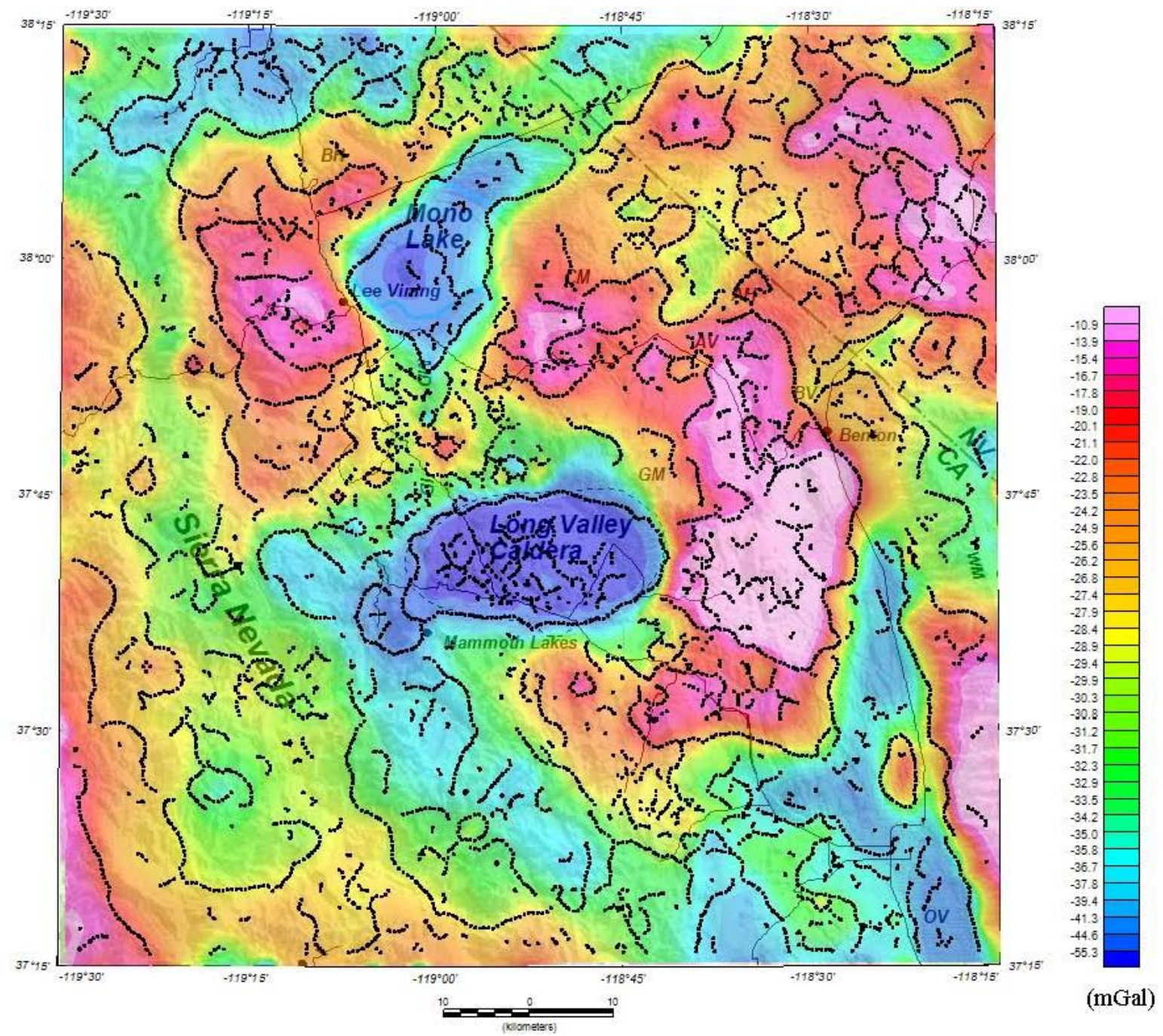

Figure 17. Isostatic gravity anaomaly map of the Mono Basin study area. Black dots represent maximum horizontal gradients derived from the isostatic gravity data. 


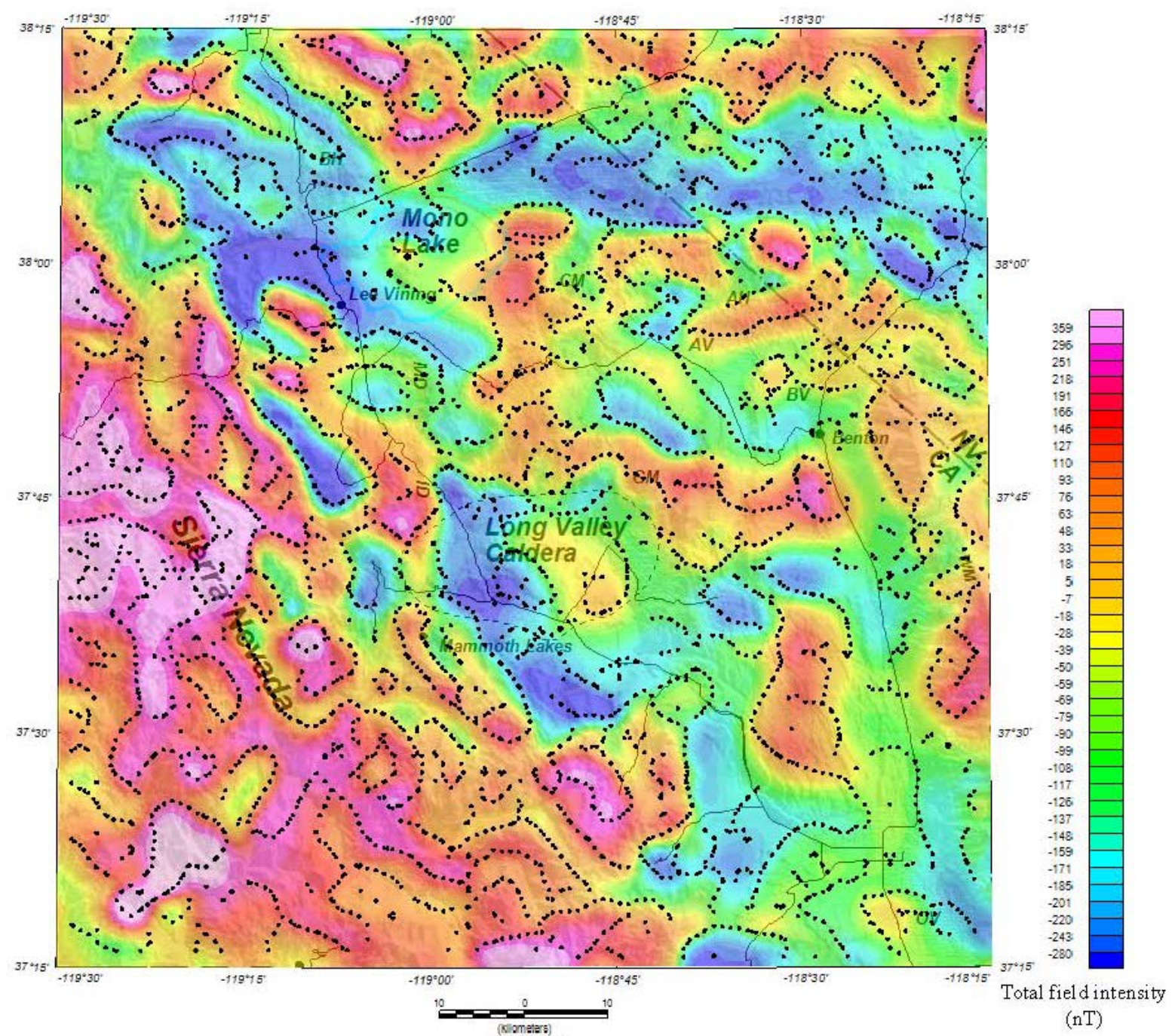

Figure 18. Aeromagnetic anomaly map of the Mono Basin study area. Black dots show maximum horizontal gradients derived from the magnetic potential data. 


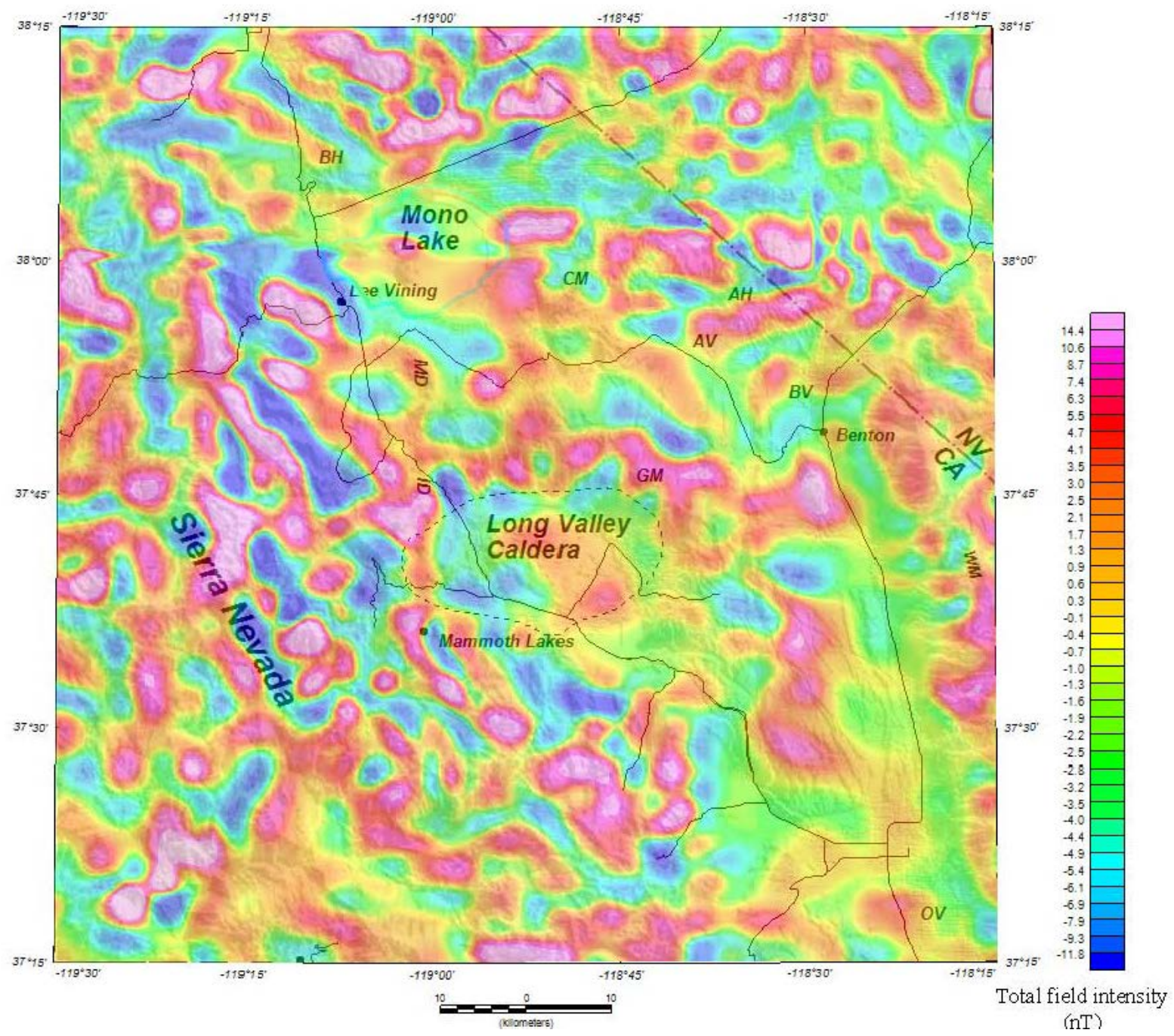

Figure 19. Residual, or shallow, magnetic map of the aeromagnetic data emphasizing anomalies in the upper $100 \mathrm{~m}$ of the crust. 


\section{MODELING}

We produced two geophysical forward models from gravity and aeromagnetic data taken along an east-west profile across the northern end of the Mono Domes (Profile A-A' is displayed on Figures 2, 10, and 13). An interactive gravity and magnetic modeling program, GM-SYS, was used to create geologic models of the subsurface (Fig. 20 and 21). Gravity and magnetic models are non-unique and many models can be constructed to fit the given dataset. Additional independent information is needed to help constrain the geophysical models.

Velocity data are used as a reference to constrain the depth and geometry of the basin along with the densities used in the model. The seismic velocity model shows layers of contrasting density within the basin and suggests the depth of the basin to be roughly $600 \mathrm{~m}$ (Hill and others, 1985). Seismic velocities taken from the seismic refraction survey colocated with our gravity and magnetic forward model are converted to densities using the formula

$$
\rho=1740 \mathrm{v}^{1 / 4}
$$

where $\rho$ is density in $\mathrm{kg} / \mathrm{m}^{3}$ and $\mathrm{v}$ is the velocity in $\mathrm{km} / \mathrm{s}$ (Gardner et al., 1974; Table 3). The velocity data were used to constrain the depth and geometry of the basin and the densities used in the model. 


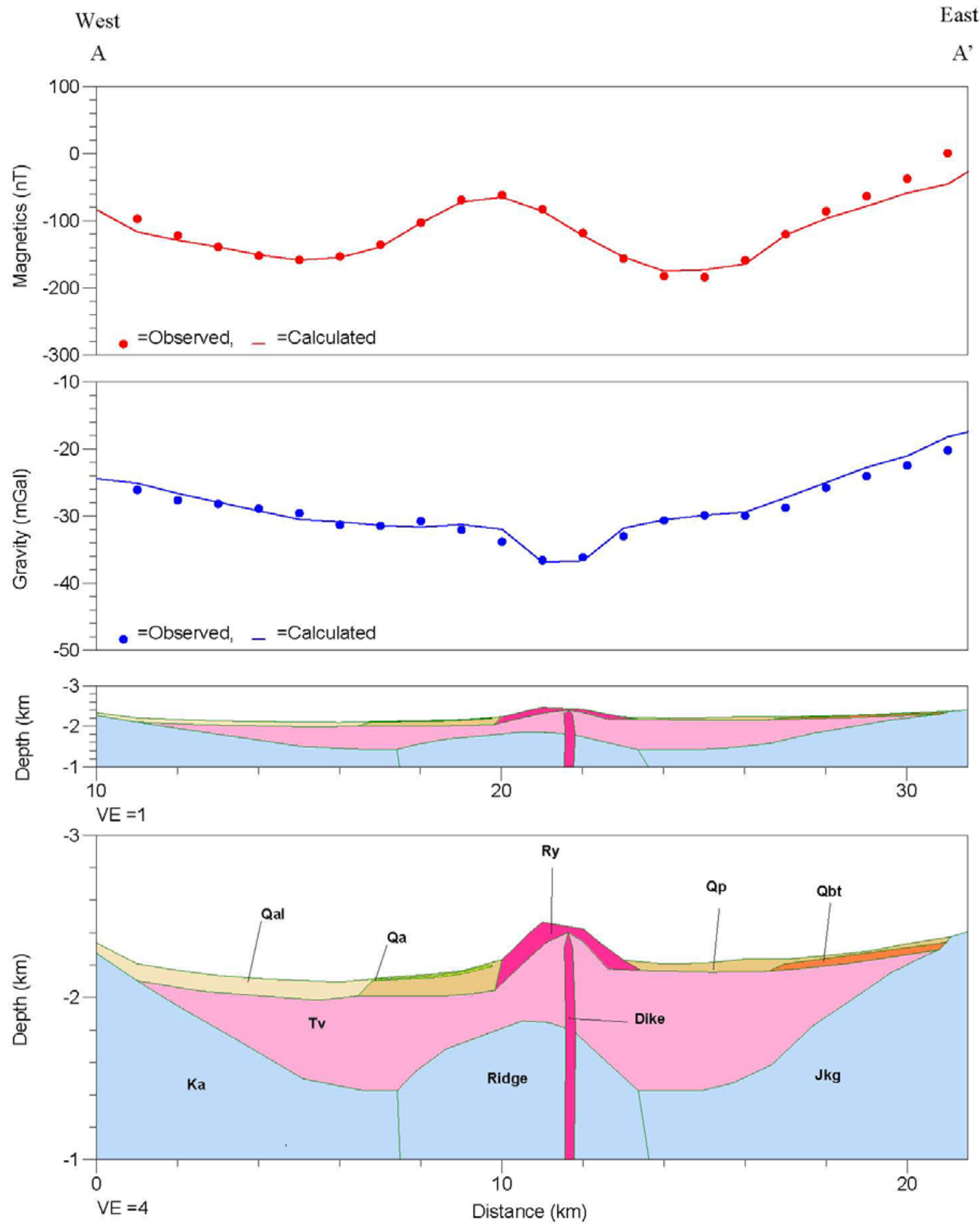

Figure 20. Model A, showing a subsurface basement ridge. Qal, alluvium; Qa, andesite; Qp, rhyolitic pumice and ash; Ry, rhyolite; Qbt, Bishop Tuff; Tv, volcanic basin fill; Ka (western basement block), quartz monzonite of Aeolian Buttes; Jkg (eastern basement block), granodiorite, diorite and gabbroic rocks. See Table 4 for model parameters. 

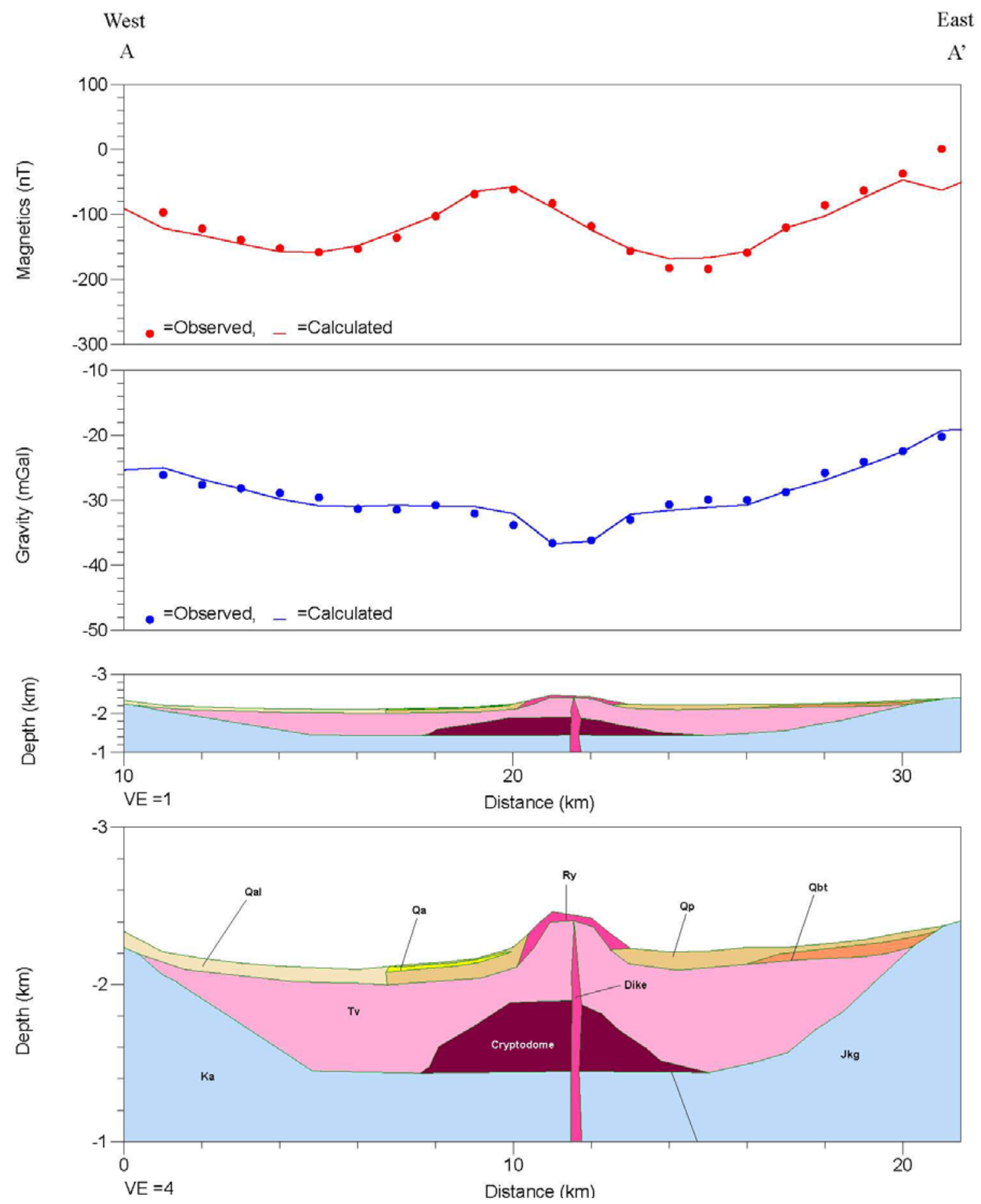

Figure 21. Model B, showing a cryptodome most likely containing basaltic materials. Qal, alluvium; Qa, andesite; Qp, rhyolitic pumice and ash; Ry, rhyolite; Qbt, Bishop Tuff; Tv, volcanic basin fill; Ka (western basement block), quartz monzonite of Aeolian Buttes; Jkg (eastern basement block), granodiorite, diorite and gabbroic rocks. See Table 4 for model parameters. 
Table 3. Velocity-to-density conversions using Gardner et al. (1978).

\begin{tabular}{|c|c|}
\hline Velocity $(\mathrm{km} / \mathrm{s})$ & Density $\left(\mathrm{kg} / \mathrm{m}^{3}\right)$ \\
\hline 1200 & 1820 \\
\hline 1250 & 1840 \\
\hline 1300 & 1860 \\
\hline 1500 & 1920 \\
\hline 2900 & 2270 \\
\hline 3000 & 2290 \\
\hline 3500 & 2380 \\
\hline 3600 & 2400 \\
\hline 3900 & 2450 \\
\hline 4000 & 2460 \\
\hline 4100 & 2480 \\
\hline 4900 & 2590 \\
\hline 5500 & 2670 \\
\hline 5600 & 2680 \\
\hline 5750 & 2700 \\
\hline
\end{tabular}

Surface geology used to constrain shallow densities in the model, consists of Bishop Tuff, andesite, alluvium, rhyolite, and rhyolitic pumice and ash outcrops (Bailey, 1989). The 
basin fill consists of a mixture of rhyolite, andesite and basalt, flows, tuff, fragments, ash, and pumice inter-bedded with lacustrine sediments, based on units encountered in the Mono Craters tunnel drilling project and from geothermal wells drilled on the shores of Mono Lake (Gresswell, 1940; Axtell, 1972). A 60-m thick layer of Bishop Tuff is presumed to be located on the eastern boundary of the basin and is overlain by a thin layer of rhyolitic pumice and ash, as suggested by two outcrops (Bailey, 1989). A rhyolitic feeder dike probably serves as the conduit for the dome (Bailey, 1989).

Our two geophysical models (Figs. 20 and 21) have a crystalline basement composed of a standard crustal density of $2670 \mathrm{~kg} / \mathrm{m}^{3}$ down to a depth of $1.3-1.5 \mathrm{~km}$. The composition of crystalline basement in the model varied from west to east and was determined from geologic maps (Kistler, 1966; Bailey 1989). The west side of the basement including the basement ridge is assumed to be the same quartz monzonite of Aeolian Buttes, as suggested by a geologic cross section south of the profile line (Kistler,1966). The magnetic susceptibility of the quartz monzonite unit ranges from 0.012 to $0.025 \mathrm{SI}$ as determined by unpublished physical rock property measurements of the pluton (D.A. Ponce, oral commun., 2011). A magnetic susceptibility of 0.025 SI was used in the model as it best fits the data. The seismic velocity model (Fig. 22), rock property measurements (Table 1), and typical physical rock property measurements (Carmichael, 1982) were utilized when assigning both density and magnetic susceptibility values to the basin fill and surface geology in the models. Paleomagentic data (remanent magnetization) for the Bishop Tuff was also included in the models (Palmer and others, 1996). 


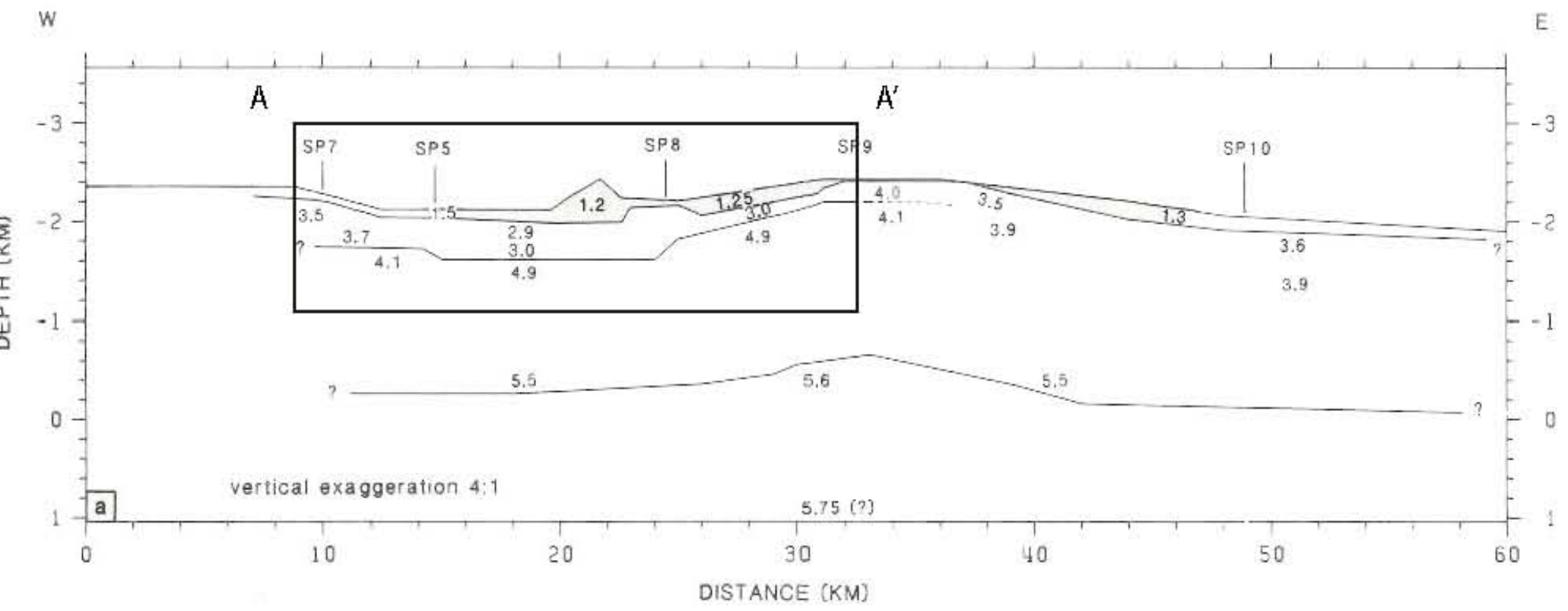

Figure 22. Seismic velocity model modified from Hill et al., 1985. Black box shows approximate location of profile A-A' and referenced velocities. 
Gravity data show a decrease of about $11 \mathrm{mGal}$ across the Mono Basin and a decrease of about $5 \mathrm{mGal}$ across the Mono Domes. Aeromagnetic data across the profile show a decrease in magnetic field of around 140 nT across the Mono Basin, however, an increase of roughly $98 \mathrm{nT}$ is observed across the Mono Domes.

Model A (Fig. 20, Table 4) suggests a basement high, or ridge, located under the Mono Domes. The ridge has an asymmetrical shape with more than half of its area west of the domes. The basin is approximately $700 \mathrm{~m}$ deep, and the basement ridge is roughly $400 \mathrm{~m}$ high, and $6 \mathrm{~km}$ wide. The construction report of the Mono Craters tunnel indicates drilling through a zone of highly fractured rock, indicating a fissure or fault zone, beneath the axis of the domes (Gresswell, 1940).

This suggests the basement rock beneath the domes has a lower density than the surrounding rock due to the fracturing caused by the eruption of the domes and/or from a preexisting fault zone. For this model a basement ridge with a slightly lower density fits the data suggesting a faulted or fractured ridge block, Model B (Fig. 21, Table 4) is derived from work conducted by Shaffer and others (2010). This suggests an elongated cryptodome as a possible source for deformation underneath the northern end of the Mono Domes. 
Table 4. Model parameters. Susc, magnetic susceptibility; M, remanent magnetization; MI, remanent inclination; MD, remanent declination; N/A, not available.

\begin{tabular}{|c|c|c|c|c|c|}
\hline \multicolumn{3}{|c|}{ Model A } & \multicolumn{3}{|c|}{ Paleomagnetic data } \\
\hline Rock unit & Density $\left(\mathrm{kg} / \mathrm{m}^{3}\right)$ & Susc (SI) & $\begin{array}{c}\mathrm{M} \\
\text { (SI) }\end{array}$ & $\begin{array}{c}\text { MI } \\
\text { (deg) }\end{array}$ & $\begin{array}{l}\text { MD } \\
\text { (deg) }\end{array}$ \\
\hline $\mathrm{Ka}$ & 2670 & 0.025 & N/A & N/A & N/A \\
\hline Jkg & 2670 & 0.018 & N/A & N/A & N/A \\
\hline Ridge block & 2600 & 0.025 & N/A & N/A & N/A \\
\hline $\mathrm{Tv}$ & 2330 & 0.001 & N/A & N/A & N/A \\
\hline Qbt & 2020 & 0.009 & 1.3 & 53 & 348 \\
\hline Qal & 1900 & 0 & N/A & N/A & N/A \\
\hline Qp & 1920 & 0 & N/A & N/A & N/A \\
\hline Qa & 2400 & 0.025 & N/A & N/A & N/A \\
\hline Dike & 1900 & 0.004 & N/A & N/A & N/A \\
\hline \multicolumn{3}{|c|}{ Model B } & \multicolumn{3}{|c|}{ Paleomagnetic data } \\
\hline $\mathrm{Ka}$ & 2670 & 0.025 & N/A & N/A & N/A \\
\hline Jkg & 2670 & 0.018 & N/A & N/A & N/A \\
\hline Cryptodome & 2400 & 0.001 & N/A & N/A & N/A \\
\hline Tv 2 & 2330 & 0.001 & N/A & N/A & N/A \\
\hline Qbt & 2020 & 0.009 & 1.3 & 53 & 348 \\
\hline Qal & 1900 & 0 & N/A & N/A & N/A \\
\hline Qp & 1920 & 0 & N/A & N/A & N/A \\
\hline Qa & 2400 & 0.023 & N/A & N/A & N/A \\
\hline Dike & 1900 & 0.004 & N/A & N/A & N/A \\
\hline
\end{tabular}


A cryptodome is formed as a dike intrudes through crystalline basement and pools along the contact between the basement and overlying sediments (Shaffer and others, 2010; Fig. 23). The cryptodome model suggests a basin depth of about $700 \mathrm{~m}$. The cryptodome is roughly $400 \mathrm{~m}$ thick and $6.5 \mathrm{~km}$ wide and is asymmetrically located slightly to the west beneath the Mono Domes. The density contrast between the cryptodome and the surrounding basin fill is relatively small. The magnetic susceptibility of the cryptodome is $0.025 \mathrm{SI}$ (see Table 4) assuming it has a basaltic composition. Magnetic susceptibilities of the basement rock are the same as in Model A (Fig. 20).

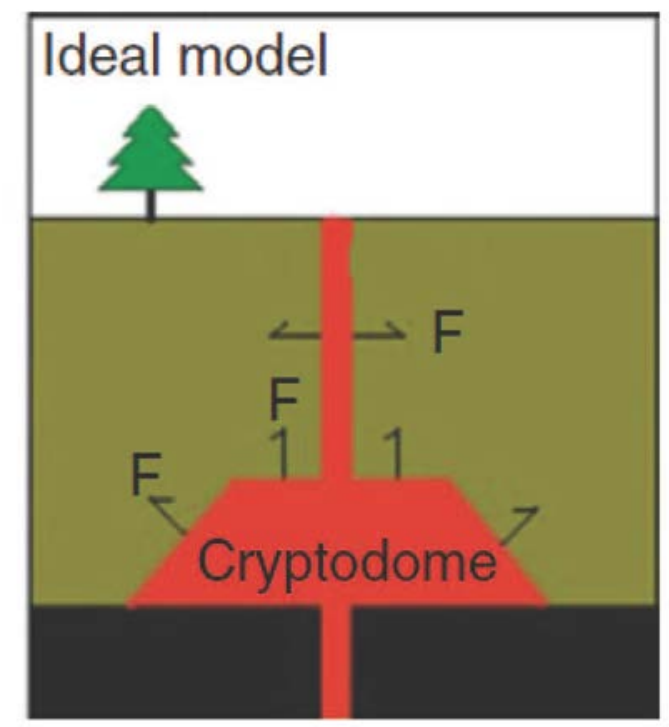

Figure 23. Model of a cryptodome from (Shaffer and others, 2010).

Ground magnetic data collected along profile A-A' (Fig. 24) shows a magnetic anomaly on the order of $180 \mathrm{nT}$ just west of the Mono Domes near the location where the aeromagnetic high was observed. However, neither of the geophysical models produced a 
magnetic anomaly great enough to match that of the magnetic high shown in the ground magnetic data. In order to fit the ground magnetic anomaly, a magnetic susceptibility of about 0.040 SI or greater would need to be given to a body about 4-km wide and roughly as deep as the basin.

It is possible that near-surface manmade magnetic objects could be affecting the ground magnetic data, producing a magnetic field not representative of the subsurface geology. Near-surface features would not be resolved in this aeromagneticdataset due to poor resolution, possibly accouting for the difference between the two datasets. The poor resolution of the aeromagnetic data also could affect the magnetic field intensity shown on the aeromagnetic anomaly map. 


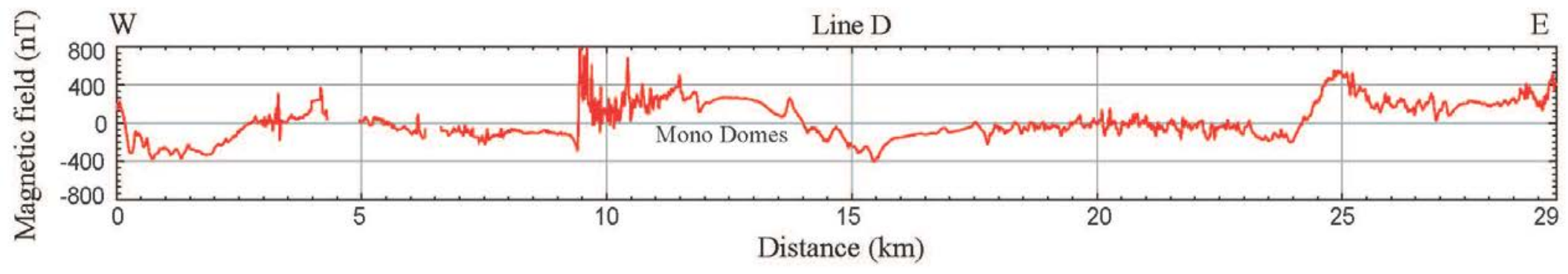

Figure 24. Ground magnetic data collected adjacent to profile A-A'. See Figure 11 for location of Line D. 


\section{DISCUSSION}

In general, gravity highs in the study area reflect high-density plutonic rocks on the east and west sides of the Mono basin where granitic outcrops are exposed. Gravity lows are observed in Mono Lake and the Long Valley caldera where low-density volcanic rocks and sediments are prevalent; the boundaries of these features are distinctively marked by maximum horizontal gradients. In general, magnetic anomalies reflect moderately magnetic plutonic and volcanic rocks throughout the region. Within the study area, aeromagnetic data reveal an anomalous ring-shaped magnetic high centered over Aeolian Buttes whose eastern boundary follows the arcuate trend of the Mono Domes. The maximum horizontal gradient, reduction-to-the-magnetic-pole (RTP) and residual maps all clearly define the circular magnetic anomaly. The boundaries of the anomaly are delineated in the RTP and horizontal gradient maps. The residual map suggests the source of the anomaly is greater than $100 \mathrm{~m}$ deep and not related to nearsurface features. Ground magnetic transects throughout the basin on the west side of the Mono Domes show magnetic lows and highs that correlate with the ring-shaped feature shown in the aeromagnetic data (Fig. 25). 


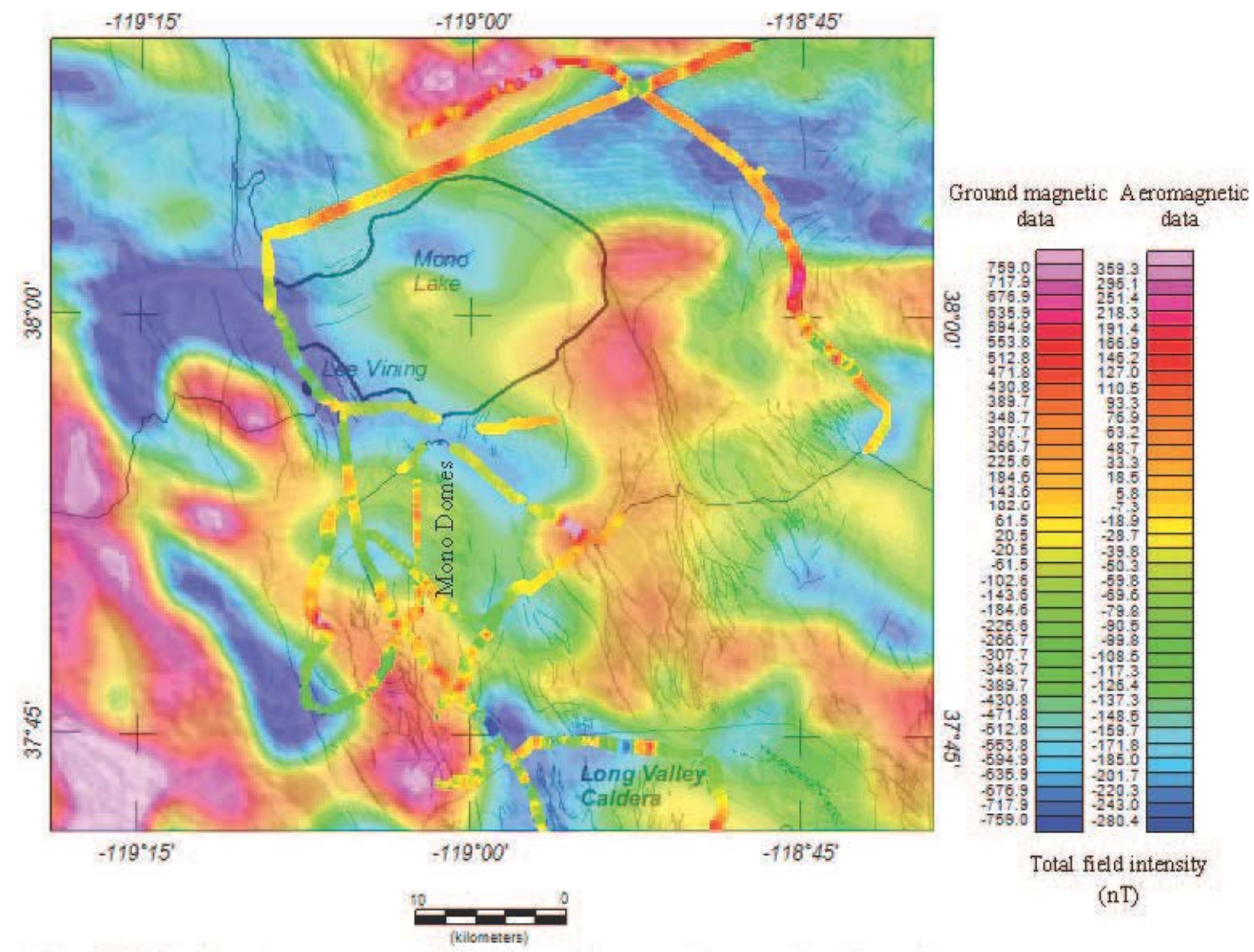

Figure 25. Map showing aeromagnetic data overlaid with truck-towed and ground magnetic data. Note truck-towed/ground magnetic data and aeromagnetic data do not have the same color scale. Truck-towed/ground magnetic data show highs and lows that correlate with aeromagnetic data in the region around the ring-shaped magnetic high, located west of the Mono Domes.

The preferred potential-field model that best supports previous work done in the area is the basement ridge model (Model A, Fig 20). This model suggests that a basement structure, or ridge, is located beneath the Mono Domes with its apex to the west of the domes. Re-analysis of seismic refraction data indicates a basement structure may be present beneath the Mono Domes, as suggested by further evaluations of first-arrival times (D. Hill, oral commun; 2011). The ridge is likely to be fractured and faulted, 
possibly due to a pre-existing fault zone which could have served as a conduit for the eruption of the Mono Domes, reducing the ridge's density relative to the surrounding basement rock. The circular geometry of the ridge suggested by the ring-shaped magnetic anomaly is perplexing. Regional tectonics, extensional basin and range faulting, or complicated structural trends throughout the area could have influenced the formation the ridge beneath the domes. The ridge could be part of a horst-and-graben structure, considering the extensional structural trends throughout the region. Poor resolution of the aeromagnetic data may distort the geometry and boundaries of the anomalous magnetic high, possibly causing independent structures to appear as if they have a continuous circular shape. High-resolution aeromagnetic surveys may help delimit the circular magnetic anomaly and determine whether it could instead be the result of intersecting linear features.

The alternate model (Model B, Fig. 21), indicates a cryptodome could be the source of the magnetic anomaly across the Mono Domes. If a cryptodome is present it is possible that dense basaltic materials were trapped in the cryptodome as lighter, less dense rhyolites were erupted. Basaltic dikes 8 to $14 \mathrm{~m}$ wide were encountered around the rhyolitic Mono-Inyo feeder dike during the drilling of the Inyo Domes (Heiken and others, 1988), indicating that basaltic rock could be trapped around the Mono Domes conduit. Because basaltic materials have a much higher magnetic susceptibility than rhyolites, a basaltic body located beneath the Mono Domes could be the source of the magnetic high along the profile line. It is unlikely that basaltic intrusions like those found around the Inyo Domes would be the source of the magnetic anomaly because the 
modeled width of these dikes were too narrow to produce an anomaly great enough to match the data. However, a large mass of moderately magnetic basaltic rock trapped in a cryptodome could produce a magnetic anomaly great enough to match the magnetic data in the model. Evidence for cryptodome deformation was observed at the northernmost end of the Mono Domes, near Panum crater (Shaffer and others, 2010). If basaltic rock was trapped by cryptodomes during the eruptions of the Mono Domes, the ring-shaped magnetic high should extend closer to the shoreline of Mono Lake. The location of cryptodome deformation does not correlate with the ring-shaped magnetic high, suggesting that a cryptodome is not likely to be associated with the magnetic anomaly located under the Mono Domes.

The anomalous ring-shaped magnetic high is essentially coincident with a ring fracture mapped by Kistler (1966) (Fig. 26). The ring fracture follows the trend of the Mono Domes; the magnetic high diverges from the domes at North Coulee and runs parallel to the northern trace of the ring fracture. The similarity of both trends could imply that the ring fracture and the magnetic high, or modeled basement ridge, are associated. 


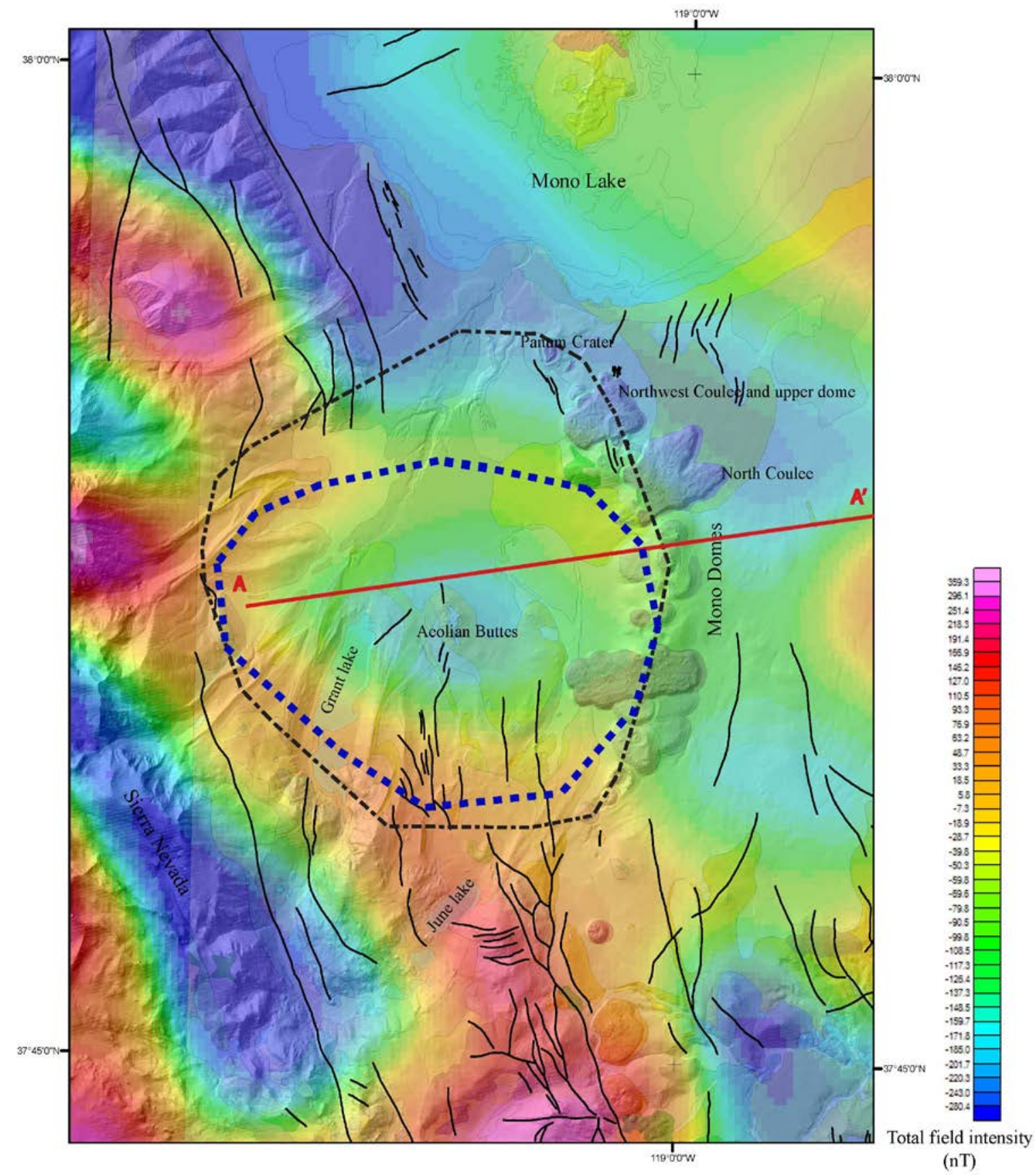

Figure 26. Interpretive map showing geologic map (Bailey, 1989) overlaid with aeromagnetic map (Roberts and Jachens, 1999). Black dashed circle shows location of ring fracture mapped by Kistler (1966). Blue dashed line shows location of interpreted ring-shaped magnetic high. The ring-shaped magnetic high is centered over Aeolian Buttes and coincides with the ring fracture with the exception of the northern trace. Profile A-A' (red line) extends off the map to the east. 
In the event that volcanic activity occurs again in the region, eruptions could be focused within the pre-existing fracture zone beneath the domes, possibly continuing its arcuate trend to the west along the ring fracture trace. The close correlation between the circular magnetic anomaly and ring fracture has not been closely evaluated; it would be beneficial to investigate this relationship further to determine if the association holds any implications for future volcanic activity, but a higher resolution aeromagnetic survey would be required for any further analysis.

The most recent volcanic activity in the region occurred $250 \pm 50$ years ago at the northern end of the Mono-Inyo volcanic chain, forming Pahoa Island and Negit Island. The history of volcanic eruptions over the past 5000 years includes 20 small eruptions at 250-700 year intervals. Given the locations and intervals of eruptions, it is possible the magma chamber for the Mono-Inyo volcanic system could be utilized as a geothermal resource similar to the Casa Diablo geothermal plant located to the south of the Mono Basin, if a significant magma body can be located within the subsurface. We provide a useful foundation from which to continue investigations in this area to assess the geothermal potential the region may hold.

To better define the geometry and location of the basement ridge additional geophysical studies of the area are needed. Paleomagnetic data, which would provide remnant magnetizations of both volcanic and basement rocks, would be useful to constrain the geometry and size of the basement ridge. Additionally, high-resolution 
aeromagnetic data would better define the boundaries of the circular-shaped magnetic high.

\section{CONCLUSIONS}

Geophysical models of the Mono Domes show that a moderately magnetic structure, 6 -km wide, with about $400 \mathrm{~m}$ of relief, and at a depth of about $700 \mathrm{~m}$ could be located beneath and slightly to the west of Mono Domes. Potential-field models indicate the basin depth to be roughly $700 \mathrm{~m}$ in Pumice Valley. The basement structure may be a fractured ridge, the eastern edge of which could have provided a pathway for the Mono Domes feeder dike. Re-evaluation of a seismic refraction survey conducted in 1985 supports the likelihood of a basement structure. Aeromagnetic data suggests the ridge has a circular geometry. Alternately, the unusual geometry could be due to complicated intersecting structural trends in the area, attributable to the combination of the Mina Deflection, Sierran frontal fault systems, and Basin and Range faulting. A ring fracture mapped by Kistler (1966) coincides with the circular magnetic anomaly, suggesting the two features may be associated. The ring fracture may have been the pre-existing fracture zone that served as the conduit for the Mono Domes feeder dike. Additional geophysical studies are needed to further delineate the shape and origin of the basement ridge. 


\section{REFERENCES CITED}

Achauer, U., Greene, L., Evans, J.R., and Iyer, H.M., 1986, Nature of the magma chamber underlying the Mono Craters area, Eastern California, as determined from teleseismic travel time residuals: Journal of Geophysical Research, v. 91, no. B14, p. 13,873-13,891.

Axtell, L.H., 1972, Mono Lake geothermal wells abandoned: California Geology, v. 25, p. $66-68$.

Bailey, R., Dalrymple, G.B., and Lanphere, M.A., 1976, Volcanism, structure and geochronology of Long Valley Caldera, Mono County, California: Journal of Geophysical Research, v. 81, no. 5, p. 725-744.

Bailey, R.A., 1982, Chemical evolution and current state of the Long Valley magma chamber,U.S. Geological Survey, Open-File Report, 84-939, p. 24-40.

Bailey, R., 1989, Geologic map of Long Valley Caldera, Mono-Inyo Craters volcanic chain, andvicinity, Eastern California: U.S. Geological Survey, scale 1:62,500, 2 sheets, $11 \mathrm{p}$.

Barnes, D.F., Oliver, H.W., and Robbins, S.L., 1969, Standardization of gravimeter calibrations in the Geological Survey: Eos, Transactions, American Geophysical Union, v. 50, no. 10, p. 626-627.

Battaglia, M., Williams, M.J., Venezky, D.Y., Hill, D.P., Langbein, J.O., Farrar, J.F., Howle, M., Sneed, M., Segall, P., 2003, Long Valley Caldera GIS database, U.S. Geological Survey, Digital Data Series DDS-81.

Blakely, R.J., and Simpson, R.W., 1986, Approximating edges of source bodies from gravity or magnetic data: Geophysics, v. 51, p. 1494-1498.

Blakely, R.J., 1995, Potential theory in gravity and magnetic applications: New York, Cambridge University Press, $441 \mathrm{p}$.

Bursik, M., and Sieh, K., 1989, Range front faulting and volcanism in the Mono Basin, Eastern California: Journal of Geophysical Research, v. 94, no. B11, p. 15, 587-15,609. 
Bursik, M., Renshaw, C., McCalpin, J., and Berry, M., 2003, A volcanotectonic cascade: Activation of range front faulting and eruptions by dike intrusion, Mono Basin -

Long Valley Caldera, California: Journal of Geophysical Research, v. 108, no. b8, 2393, doi:10.1029/2002JB002032.

Carmichael, R.S., 1982, Handbook of physical rock properties: CRC Press, Boca Raton, Fla. Vol. III.

Christensen, M.N., Gilbert, C.M., Lajoie, K.R., and Al-Rawi, Yehya, 1969, Geologicalgeophysical interpretation of Mono Basin, California-Nevada: Journal of Geophysical

Research, v. 74, no. 22, p. 5221-5239.

Gardner, G.H.F., Gardner, L.W., and Gregory, A.R., 1974, Formation of velocity and density; The diagnostic basics for stratigraphic traps: Geophysics, v.39, p. 770-780.

Gilbert, C.M., Christensen, M.N., Al Rawi, Y., and Lajoie, K.R., 1968, Structural and volcanic history of Mono Basin, California-Nevada: Geological Society of America Memoirs,116, p. 275-329.

Godson, R.H., and Plouff, Donald, 1988, BOUGUER version 1.0, a microcomputer gravity-terrain-correction program: U.S. Geological Survey Open-File Report 88644-A, Documentation, 22 p.; 88-644-B, Tables, 61 p., 88-644-C, 5 1/4 - in diskette.

Gresswell, W.K., 1940, Short report on the geological formations encountered in driving the Mono Craters tunnel: California Division of Mines and Geology Bulletin, v. 36, p. 199- 204.

Hayford, J.F., and Bowie, William, 1912, The effect of topography and isostatic compensation upon the intensity of gravity: U.S. Coast and Geodetic Survey Special Publication no. 10, 132 p.

Henry, C.D., and Faulds, J.E., 2005, Coupled magmatic-tectonic evolution of the Walker Lane, Western Nevada and eastern California, in Proceedings, Penrose 
Conference: Kinematics and Geodynamics of Inraplate Dextral Shear in Eastern California and Western Nevada, p. 18-19.

Hermance, J.F., Slocum, W.M., and Neumann, G.A., 1984, The Long Valley/Mono Basin volcanic complex: A preliminary magentotelluric and magnetic variation interpretation: Journal of Geophysical Research, v. 89, no. B10, p. 8325-8337.

Heiken, G.H., Wohletz, K.H., and Eichelberger, J.C., 1988, Fracture fillings and intrusive Pyroclasts, Inyo Domes, California: Journal of Geophysical Research, 93, p. 4335-4350.

Hildreth, W., 2004, Volcanological perspectives on Long Valley, Mammoth Moutain, and Mono Craters: several contiguous but discrete systems: Journal of Volcanology and Geothermal Research, 136, p.169-198.

Hill, D.P., Kissling, E., Luetgert, J.H., Kradolfer, U., 1985, Constraints on the upper structure of the Long Valley-Mono Craters volcanic complex, Eastern California, from seismic refraction experiments: Journal of Geophysical Research, v. 90, no. B13, p. 11,135 -11,150.

Hill, D.P., 2006, Unrest in Long Valley Caldera, California: 1978-2004, in Troise, C., De Natale, G., \& Kilburn, C.R.J. (eds) Mechanisms of Activity and Unrest at Large Calderas, Geological Society, London, Special Publication 269, pp. 1-24.

International Union of Geodesy and Geophysics, 1971, Geodetic reference system 1967: International Association of Geodesy Special Publication no. 3, 116 p.

Jachens, R.C., and Roberts, C.W., 1981, Documentation of a FORTRAN program, 'isocomp', for computing isostatic residual gravity: U.S. Geological Open-File Report 81-574, 26 p.

Jacques, H.L., 1940, Mono Craters tunnel construction problems: Journal of the American Water Works Association, v. 32, no. 1, p. 43-56.

Jennings, C.W., Strand, R.G., and Rogers, T.H., 1977, Geologic map of California: California Division of Mines and Geology, scale 1:750,000

Kister, R.W., 1966, Structure and metamorphism in the Mono Craters quadrangle, Sierra Nevada, California: U.S. Geol. Surv. Bull. 122-E, p. E1-E53. 
Lee, J., and Stockli, D., 2005, Fault slip transfer in the eastern California shear zone/Walker Lane belt, in Proceedings, Penrose Conference: Kinematics and Geodynamics of Inraplate Dextral Shear in Eastern California and Western Nevada, p. $7-8$.

Morelli, C., ed., 1974, The International Gravity Standardization Net 1971: International Association of Geodesy Special Publication no. 4, 194 p.

Pakiser, L.C., Press, F., and Kane, M.F., 1960, Geophysical investigation of Mono Basin, California: Bulletin of the Geological Society of America, v. 71, p. 415-448.

Pakiser, L.C., 1976, Seismic exploration of Mono Basin, California: Journal of GeophysicalResearch, v. 81, no. 20, p. 3607-3618.

Palmer, H.C., MacDonald, W.D., Gromme, C.S., and Ellwood, B.B., 1996, Magnetic properties and emplacement of the Bishop Tuff, California: Bulletin of Volcanology,v.58, p. 101-116.

Plouff, Donald, 1966, Digital terrain corrections based on geographic coordinates [abs.]: Geophysics, v. 31, no. 6, p. 1208.

Plouff, Donald, 1977, Preliminary documentation for a FORTRAN program to compute gravity terrain corrections based on topography digitized on a geographic grid: U.S. Geological Survey Open-File Report 77-535, 45 p.

Roberts, C.W., and Jachens, R.C., 1999, Preliminary aeromagnetic anomaly map of California: U.S. Geological Survey Open-File Report 99-440, 14 p.

Schaffer, W., Bursik, M., and Renshaw., C., 2010, Elastic source model of the North Mono eruption (1325-1368 A.D.) based on shoreline deformation; Bulletin of Volcanology, doi 10.1007/s00445-010-0385-4.

Sieh, K., and Bursik, M., 1986, Most recent eruption of the Mono Craters, Eastern Central California: Journal of Geophysical Research, v. 91, no. B12, p. $12,539-12,571$.

Stewart, J.H., and Carlson, J.E., 1978, Geologic map of Nevada: U.S. Geological Survey, scale 1:500,000. 
Swick, C.A., 1942, Pendulum gravity measurements and isostatic reductions: U.S. Coast and Geodetic Survey Special Publication 232, 82 p. 
APPENDIX A

GRAVITY BASE STATIONS 
GRAVITY BASE STATION

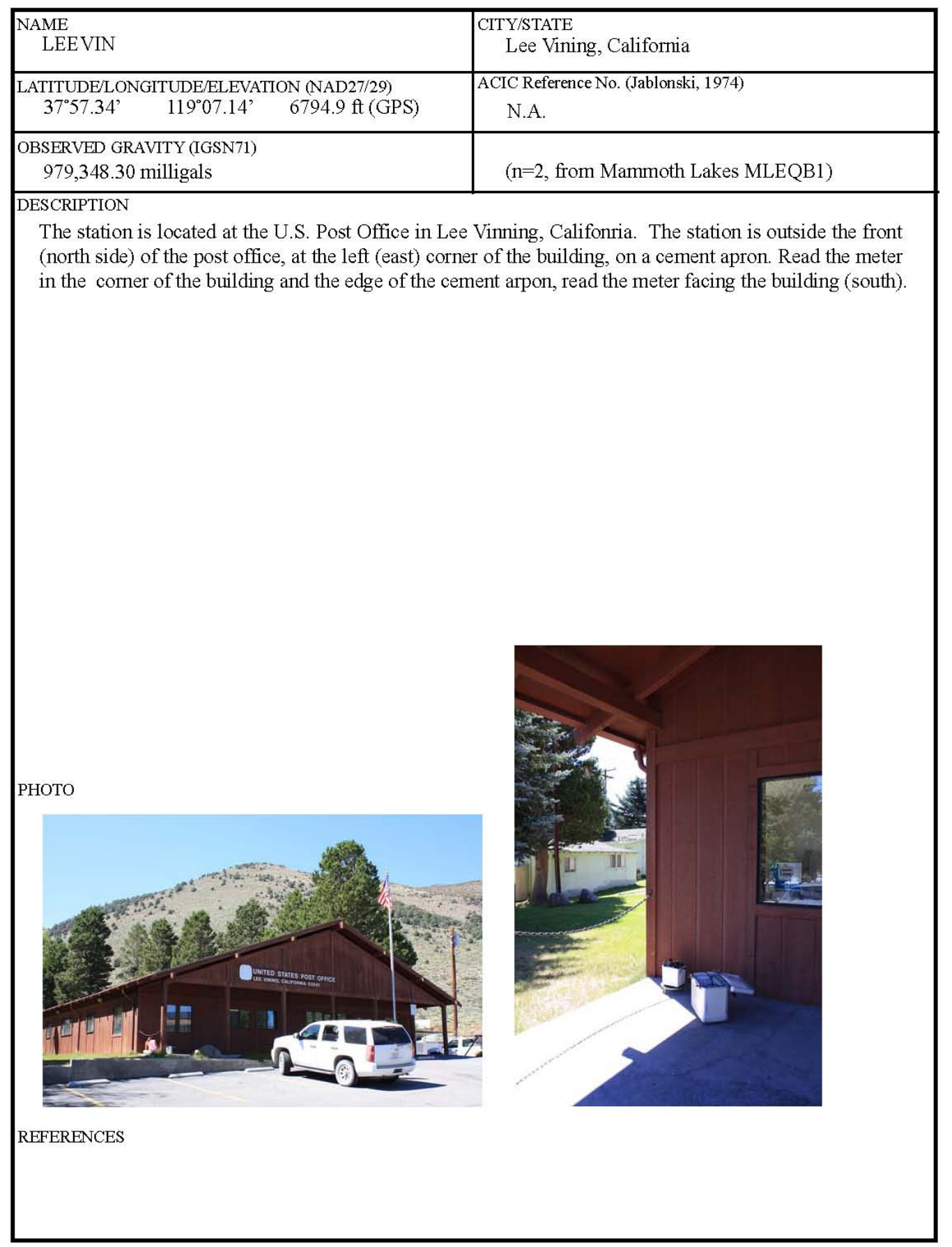


GRAVITY BASE STATION

\begin{tabular}{|c|c|}
\hline $\begin{array}{l}\text { NAME } \\
\text { MLEBQ1 }\end{array}$ & $\begin{array}{l}\text { CITY/STATE } \\
\text { Mammoth Lakes/Toms Place, California }\end{array}$ \\
\hline $\begin{array}{l}\text { LATITUDE/LONGITUDE/ELEVATION (NAD27/29) } \\
37^{\circ} 33.80^{\prime} \quad 118^{\circ} 41.68^{\prime} \quad 6951.5 \mathrm{ft} \text { (GPS) }\end{array}$ & $\begin{array}{l}\text { ACIC Reference No. (Jablonski, 1974) } \\
\text { N.A. }\end{array}$ \\
\hline $\begin{array}{l}\text { OBSERVED GRAVITY (IGSN71) } \\
979,312.160 \text { milligals }\end{array}$ & \\
\hline \multicolumn{2}{|c|}{$\begin{array}{l}\text { DESCRIPTION } \\
\text { Station is located near the intersection of U.S. Highway } 395 \text { and Rock Creek Road at Toms Place, south } \\
\text { of Mammoth Lakes, California. From Toms Place and Highway } 395 \text { drive west } 0.8 \text { mi on Rock Creek } \\
\text { Road, then turn right on Rainbow Tarns Road, then } 0.3 \text { mi north. Station is beyond a gated fence, at the } \\
\text { edge of a small grassy meadow, on a granitic boulder at the base of a rocky hill, on the north side of the } \\
\text { meadow. Site is midway along top of rock about } 6 \mathrm{ft} \text { above the meadow, and marked with a standard USGS } \\
\text { hexagonal gravity marker stamped MLEQB1 } 1980 \text {. Read with the meter facing north. Description revised } \\
6 / 2010 \text {. }\end{array}$} \\
\hline
\end{tabular}

PHOTO (by D.A. Ponce, U.S. Geological Survey, 2010)
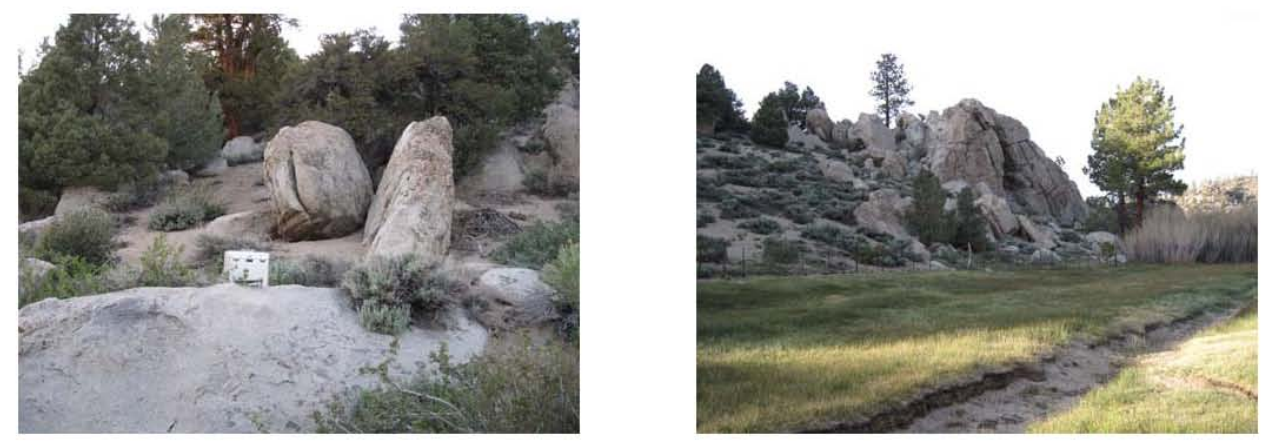

REFERENCES

Roberts, C.W., Jachens, R.C., and Morin, R.L., 1988, High-precision stations for monitoring gravity changes in Long Valley caldera, California: U.S. Geological Survey Open-File Report 88-50, 19 p. 


\section{APPENDIX B}

PHYSICAL ROCK PROPERTIES 


\begin{tabular}{|c|c|c|c|c|c|c|c|c|c|}
\hline & Type & Grain Density & GD Ave & Sat. Blk Density & SBD Ave & Dry Bulk Density & DBD Ave & SUSC & SUSC Ave \\
\hline Sample ID & & $\leftarrow$ & & $=\mathrm{kg} / \mathrm{m}^{3}$ & & & $\longrightarrow$ & $\longleftarrow$ & $\mathrm{SI} \longrightarrow$ \\
\hline 10AAPM02A & \multirow{5}{*}{ BA } & 2488 & \multirow{5}{*}{2557} & 2329 & \multirow{5}{*}{1970} & 2222 & \multirow{5}{*}{2363} & 20.87 & \multirow{5}{*}{13.48} \\
\hline 10AAPM02B & & 2459 & & 2319 & & 2224 & & 12.79 & \\
\hline 10AAPM02C & & 2485 & & 2395 & & 2335 & & 8.02 & \\
\hline 10AAPM02D & & 2508 & & 2.354 & & 2252 & & 14.1 & \\
\hline 09MB0004 & & 2847 & & 2806 & & 2783 & & 11.6 & \\
\hline 10AAPM03A & \multirow{9}{*}{$\mathrm{OB}$} & 2002 & \multirow{9}{*}{2018} & 1951 & \multirow{9}{*}{1990} & 1900 & \multirow{9}{*}{1975} & 0.56 & \multirow{9}{*}{0.78} \\
\hline 10AAPM03B & & 1782 & & 1732 & & 1669 & & 0.48 & \\
\hline 10AAPM06B & & 2153 & & 2122 & & 2096 & & 1.47 & \\
\hline 10AAPM06C & & 2194 & & 2120 & & 2057 & & 1.72 & \\
\hline $10 \mathrm{MB} 0020 \mathrm{~A}$ & & 1448 & & 1535 & & 1731 & & 0.39 & \\
\hline 10MB0020B & & 2091 & & 2045 & & 2004 & & 0.68 & \\
\hline $10 \mathrm{MB} 0020 \mathrm{C}$ & & 2157 & & 2116 & & 2081 & & 0.62 & \\
\hline $10 \mathrm{MB} 0020 \mathrm{D}$ & & 2264 & & 2249 & & 2224 & & 0.84 & \\
\hline 10MB0020E & & 2073 & & 2040 & & 2009 & & 0.25 & \\
\hline $10 \mathrm{MB} 0028 \mathrm{~A}$ & \multirow{3}{*}{ GD } & 2665 & \multirow{3}{*}{2684} & 2627 & \multirow{3}{*}{1983} & 2605 & \multirow{3}{*}{2629} & 10.95 & \multirow{3}{*}{13.21} \\
\hline 10MB0028B & & 2688 & & 647 & & 2623 & & 12.75 & \\
\hline $10 \mathrm{MB} 0028 \mathrm{C}$ & & 2699 & & 2674 & & 2660 & & 15.92 & \\
\hline 10ELL001A & \multirow{6}{*}{$\mathrm{TU}$} & 2130 & \multirow{6}{*}{1935} & 1879 & \multirow{6}{*}{1687} & 1656 & \multirow{6}{*}{1419} & 2.85 & \\
\hline 10EEL001B & & 2038 & & 1756 & & 1484 & & 2.85 & \\
\hline 10EEL001C & & 2058 & & 1774 & & 1506 & & 3 & \\
\hline 10MB0064A & & 1377 & & 1274 & & 1001 & & 1.43 & 2.46 \\
\hline 10MB0064B & & 1924 & & 1649 & & 1351 & & 1.78 & \\
\hline 10EEL001D & & 2084 & & 1789 & & 1516 & & 2.84 & \\
\hline 10AAPM05B & & 2278 & & 2216 & & 2167 & & 5.77 & \\
\hline 10AAPM05C & & 2292 & & 2206 & & 2140 & & 5.25 & \\
\hline 10AAPM04A & & 2167 & & 2200 & & 2228 & & 0.51 & \\
\hline 10AAPM04B & & 2062 & & 1970 & & 1883 & & 0.46 & \\
\hline 10AAPM04C & & 2217 & & 2147 & & 2089 & & 0.51 & \\
\hline 10AAPM04D & & 2152 & & 2058 & & 1976 & & 0.56 & \\
\hline 10AAPM05A & & 2161 & & 2094 & & 2037 & & 5.33 & \\
\hline 10AAPM06A & $\mathrm{RH}$ & 1916 & & 1843 & 1774 & 1765 & 1687 & 1.09 & \\
\hline $10 \mathrm{MB} 0131 \mathrm{~A}$ & RH & 1304 & 1831 & 1252 & 1774 & 1080 & 1687 & 0.26 & 1.50 \\
\hline 10MB0131B & & 1231 & & 1205 & & 1092 & & 0.28 & \\
\hline $10 \mathrm{MB} 0075 \mathrm{~A}$ & & 1560 & & 1505 & & 1406 & & 0.53 & \\
\hline 10MB0075B & & 1854 & & 1809 & & 1758 & & 0.73 & \\
\hline 10AAPM01A & & 1377 & & 1274 & & 1001 & & 1.43 & \\
\hline 10AAPM01B & & 1497 & & 1443 & & 1334 & & 0.61 & \\
\hline 10AAPM01C & & 1461 & & 1421 & & 1335 & & 0.24 & \\
\hline $09 \mathrm{MB} 0003$ & & 1773 & & 1739 & & 1694 & & 0.41 & \\
\hline $10 \mathrm{MB} 0115 \mathrm{~A}$ & & 2693 & & 2649 & & 2624 & & 13.22 & \\
\hline 10MB0115B & & 2685 & & 2635 & & 2605 & & 13.74 & \\
\hline 10MB0115C & & 2685 & & 2635 & & 2605 & & 13.08 & \\
\hline 09MB0002 & GR & 2600 & 2672 & 2540 & 2615 & 2503 & 2581 & 2.46 & 554 \\
\hline 09MB0005 & GR & 2917 & 2672 & 2865 & 2615 & 2839 & 2581 & 0.27 & 5.54 \\
\hline MLEQB1A & & 2598 & & 2531 & & 2489 & & 0.25 & \\
\hline MLEQB1B & & 2597 & & 2530 & & 2488 & & 0.29 & \\
\hline MLEQB1C & & 2604 & & 2534 & & 2491 & & 1.02 & \\
\hline $09 \mathrm{MB} 0001$ & MT & 2675 & 2675 & 2651 & 2651 & 2636 & 2636 & 0.03 & 0.03 \\
\hline
\end{tabular}

NOTES:

BA, basalt; OB, obsidian; GD, granodiorite, TU, Bishop Tuff; RH, rhyolite; GR, granite; MT, metasediment 
APPENDIX C

GRAVITY DATA 


\begin{tabular}{|c|c|c|c|c|c|c|c|c|c|c|c|c|c|c|c|c|}
\hline ID & LAT & LONG & $\mid$ ELEV_M| & OG & TG & FAC & $\mathrm{BC}$ & $\mathrm{CC}$ & ITC & OTC | & TTC & | TISOC | & FAA & SBA & CBA & ISO \\
\hline 10MB0045 & 37.8893330 & -118.9396670 & 2258.29 & 979306.4 & 979982.39 & 696.55 & -252.699 & -1.505 & 0.15 & 2.05 & 2.2 & 203.49 & 20.57 & -232.13 & -231.43 & -27.94 \\
\hline 10MB0046 & 37.8876670 & -118.9338330 & 2292.4 & 979302 & 979982.25 & 707.06 & -256.516 & -1.5 & 0.17 & 2.06 & 2.23 & 203.41 & 26.79 & -229.73 & -229 & -25.59 \\
\hline 10MB0047 & 37.8841670 & -118.9288330 & 2315.47 & 979297.7 & 979981.94 & 714.18 & -259.097 & -1.496 & 0.23 & 2.06 & 2.29 & 203.34 & 29.96 & -229.14 & -228.34 & -25 \\
\hline 10MB0048 & 37.8861670 & -118.9135000 & 2369.24 & 979289.1 & 979982.12 & 730.75 & -265.114 & -1.486 & 0.18 & 2.13 & 2.31 & 203.22 & 37.71 & -227.41 & -226.58 & -23.36 \\
\hline 10MB0049 & 37.8840000 & -118.9003330 & 2436.02 & 979278.3 & 979981.93 & 751.34 & -272.587 & -1.47 & 0.2 & 2.3 & 2.5 & & 47.66 & -224.92 & -223.89 & \\
\hline $10 \mathrm{MB} 0050$ & 37.8971670 & -118.8383330 & 2357.45 & 979298.7 & 979983.08 & 727.11 & -263.794 & -1.488 & 0.64 & 1.96 & 2.6 & 202.73 & 42.7 & -221.1 & -219.98 & -17.25 \\
\hline 10MB0051 & 37.8936670 & -118.8323330 & 2344.98 & 979301.5 & 979982.77 & 723.27 & -262.399 & -1.491 & 0.61 & 2.01 & 2.62 & 202.71 & 42.02 & -220.38 & -219.25 & -16.54 \\
\hline $10 \mathrm{MB} 0052$ & 37.8895000 & -118.8261670 & 2343.24 & 979303 & 979982.41 & 722.74 & -262.205 & -1.491 & 0.4 & 2.04 & 2.44 & 202.69 & 43.36 & -218.84 & -217.89 & -15.2 \\
\hline $10 \mathrm{MB} 0053$ & 37.8873330 & -118.8166670 & 2307.85 & 979311.4 & 979982.22 & 711.83 & -258.245 & -1.497 & 0.43 & 2.02 & 2.45 & 202.7 & 40.98 & -217.26 & 6.31 & -13.61 \\
\hline 10MB0054 & .8880000 & -118.8090000 & 2265.91 & 979317.2 & 979982.28 & 698.9 & -253.552 & -1.504 & 0.31 & 2.03 & 2.34 & 202.74 & 33.8 & -219.76 & & -16.18 \\
\hline 10MB0055 & 37.8891670 & -118.7990000 & 2249.97 & 979321.3 & 979982.38 & 693.98 & -251.768 & -1.506 & 0.24 & 1.93 & 2.17 & 202.66 & 32.92 & -218.85 & -218.19 & -15.53 \\
\hline 10MB0056 & 37.8903330 & -118.7903330 & 2235.98 & 979322.1 & 979982.48 & 689.67 & -250.202 & -1.508 & 0.08 & 1.87 & 1.95 & & 29.28 & -220.92 & -220.48 & -17.9 \\
\hline $10 \mathrm{MB} 0057$ & 37.8921670 & -118.7786670 & 2202.79 & 979326.4 & 979982.64 & 679.44 & -246.488 & -1.511 & 0.15 & 1.85 & 2 & 202.44 & 3.18 & -223.31 & -222.82 & -20.38 \\
\hline 10MB0058 & 3330 & -118.7690000 & 2221.41 & 979322.5 & 979982.48 & 685.18 & -248.572 & -1.509 & 0.22 & 1.79 & 2.01 & 202.33 & 5.23 & -223.34 & -222.84 & -20.51 \\
\hline 10MB0059 & 20000 & -118.7 & 02.36 & 979326.6 & 979982.63 & 679.31 & -246.44 & -1.511 & 18 & 1.75 & 1.93 & 2.3 & 3.32 & & -222.7 & -20.4 \\
\hline 10MB0060 & 37.8963330 & -118.7518330 & 2185.75 & 979330.5 & 979983.01 & 674.18 & -244.582 & -1.512 & 16 & 1.72 & 1.88 & & 1.66 & & & -20.34 \\
\hline 10MB0061 & 6670 & -118 & 2167.83 & 979334.4 & 979983.3 & 668.66 & -242.576 & -1.514 & 0.26 & 1.68 & 1.94 & 2.1 & 9.75 & -222.82 & 222.4 & -20.3 \\
\hline $10 \mathrm{MB} 0062$ & 37.9066670 & -118.7 & 2135.89 & 979342.9 & 979983.91 & 658.81 & -239.002 & -1.516 & 0.7 & 1.58 & 2.28 & 201.91 & 7.81 & -221.19 & -220.42 & -18.51 \\
\hline 10MB0063 & 000 & -118.7 & 2109 & 979348.3 & 979984.25 & 650.52 & -235.994 & -1.516 & 0.25 & 1.5 & 1.75 & 1.77 & 4.62 & -221.37 & -221.14 & -19.37 \\
\hline 10MB0064 & 37.91 & -118.7 & 2068.83 & 979358.8 & 979984 & 638.14 & -231.498 & -1.517 & 37 & 1.43 & 1.8 & .66 & 2.19 & 9.31 & 19.02 & -17.36 \\
\hline 10MB0065 & 37.9210000 & -118.7 & 2009.24 & 979369 & 97998 & 619.77 & -224.831 & -1.5 & 41 & 1.46 & 1.87 & & 3.56 & & & -19.34 \\
\hline 10MB0066 & 37.8656670 & -118.9 & 2399.39 & 979277.6 & 979980.32 & 740.04 & -268.487 & -1.479 & 0.18 & 2.17 & 2.35 & 203.27 & 37.34 & -231.15 & -230.28 & -27.01 \\
\hline 10MB0067 & 548330 & 280000 & 2428.1 & 979270.2 & 979979.37 & 748.89 & -271.7 & -1.472 & 0.26 & 2.21 & 2.47 & 203.3 & 39.7 & -232 & -231 & -27.7 \\
\hline 10MB0068 & 438330 & -118.9 & 3.96 & 979273.5 & 979978.41 & 738.37 & -267.88 & -1.481 & 0.08 & 2.15 & 2.23 & 3.42 & 33.45 & -234.43 & -233.68 & -30.26 \\
\hline 10MB0069 & & -118.9 & 2.08 & 979259.9 & 97997 & 759.37 & & -1.4 & & .25 & 2.34 & & & & & -29.45 \\
\hline $10 \mathrm{MB} 0070$ & 37.8251670 & -118.9800000 & 2414.99 & 979269.2 & 979976.77 & 744.85 & -270.233 & -1.476 & 0.13 & 2.18 & 2.31 & 203.27 & 7.25 & -232.99 & -232.15 & -28.88 \\
\hline $10 \mathrm{MB} 0071$ & 37.8185000 & -118.9896670 & 99.51 & 979272.5 & 979976.19 & 740.08 & -268.501 & -1.479 & 0.09 & 2.23 & 2.32 & 203.24 & 36.41 & -232.09 & -231.25 & -28.01 \\
\hline 10MB0072 & 37.8193330 & -118.9946670 & 2393.59 & 979273.1 & 979976.26 & 738.26 & -267.839 & -1.481 & 0.13 & 2.26 & 2.39 & 203.2 & 35.1 & -232.74 & -231.83 & -28.63 \\
\hline $10 \mathrm{MB} 0073$ & 37.8206670 & -119.0031670 & 2341.44 & 979282.8 & 979976.38 & 722.18 & -262.003 & -1.491 & 64 & 2.39 & 3.03 & 203.26 & 28.62 & -233.38 & -231.84 & -28.58 \\
\hline & & & 2362.2 & 979280.5 & 97997 & & & -1.4 & & 2.4 & & & & & 9.6 & -26.41 \\
\hline $10 \mathrm{MB} 0075$ & 16670 & 330 & 2436.75 & 979256.7 & 979976.73 & 751.56 & -272.668 & -1. & 2.22 & 2.51 & 4.73 & 203.01 & 1.58 & -241.09 & -237.83 & -34.82 \\
\hline $10 \mathrm{MB} 0076$ & .8263330 & -119.0200000 & 2370.7 & 979275.6 & 979976.87 & 731.2 & -265.278 & -1.486 & 1.96 & 2.5 & 4.46 & 3.09 & 9.93 & -235.34 & -232.37 & -29.28 \\
\hline 10MB0077 & 37.8301670 & -119.0243330 & 13.19 & 979286.3 & 979977.21 & 713.47 & -258.842 & -1.497 & 1.5 & 2.62 & 4.12 & 203.21 & 2.55 & -236.29 & 233.67 & -30.46 \\
\hline $10 \mathrm{MB} 0078$ & & & 91.67 & 979292.2 & 979977.65 & & & -1.5 & 0.82 & & & & & & & -29.81 \\
\hline & & & & & 97997 & & & -1.50 & & & & & 08 & & 2.94 & -29.67 \\
\hline $10 \mathrm{MB} 0080$ & 37.8440000 & -119.0388330 & 3.54 & 979299.8 & 979978.42 & 695.08 & -252.167 & -1.505 & 0.77 & 2.92 & 3.69 & 3.27 & 16.46 & -235.71 & -233.53 & -30.26 \\
\hline 10MB0081 & 37.8486670 & -119.0448330 & 2237.99 & 979304.3 & 979978.83 & 690.29 & -250.428 & -1.507 & 0.34 & 2.92 & 3.26 & 203.26 & 15.72 & -234.71 & -232.96 & -29.7 \\
\hline 10MB0082 & 37.8541670 & -119.0525000 & 2173.83 & 979316.2 & 979979.31 & 670.51 & -243.248 & -1.513 & 0.27 & 3.18 & 3.45 & 3.33 & 7.36 & -235.88 & -233.95 & -30.62 \\
\hline & & & 2152.25 & 979320.8 & & & & & 0.2 & & 3.46 & & 4.99 & & 3.89 & -30.56 \\
\hline 10MB008 & & & 2126.8 & 979325.3 & & & & & & 3.38 & 3.67 & & 1.27 & & 34.56 & -31.22 \\
\hline 10MB0085 & 37.8503330 & 19.0605000 & 2202.24 & 979310.7 & 979978.98 & 679.27 & -246.427 & -1.511 & 25 & 3.12 & 3.37 & .18 & 10.95 & -235.48 & -233.62 & -30.44 \\
\hline 10MB0086 & 37.8446670 & -119.0685000 & 2247.23 & 979302.5 & 979978.48 & 693.14 & -251.461 & -1.506 & 0.19 & 3.2 & 3.39 & 202.97 & 17.2 & -234.26 & -232.37 & -29.4 \\
\hline & & & 2318.71 & 979286.4 & 979976.16 & & & & 0.12 & 3.01 & 3.13 & & 25.44 & & -232.39 & -29.53 \\
\hline & & & & 979288.8 & & & & & 0 & 2.88 & 3.04 & & 3.33 & & -233.12 & -30.1 \\
\hline 10MB0089 & 37.8300000 & -119.0343330 & 2302.52 & 979290.6 & 979977.2 & 710.18 & -257.648 & -1.498 & 0.28 & 2.77 & 3.05 & 203.15 & 23.55 & -234.09 & -232.54 & -29.39 \\
\hline
\end{tabular}




\begin{tabular}{|c|c|c|c|c|c|c|c|c|c|c|c|c|c|c|c|c|}
\hline ID & LAT & LONG & ELEV_M & OG & TG & FAC & $\mathrm{BC}$ & $\mathrm{CC}$ & ITC & OTC & TTC | & |TISOC| & FAA & SBA & CBA & ISO \\
\hline 10MB0090 & 37.8513330 & -119.0383330 & 2251.56 & 979302.2 & 979979.06 & 694.47 & -251.945 & -1.506 & 0.74 & 2.87 & 3.61 & 203.29 & 17.57 & -234.37 & -232.27 & -28.98 \\
\hline 10MB0091 & 37.8586670 & -119.0400000 & 2207.88 & 979311.8 & 979979.71 & 681.01 & -247.058 & -1.511 & 0.23 & 3 & 3.23 & 203.36 & 13.11 & & -232.23 & -28.87 \\
\hline $10 \mathrm{MB} 0092$ & 37.8656670 & -119.0400000 & 2188.46 & 979314.5 & 979980.32 & 675.02 & -244.885 & -1.512 & 0.09 & 3.02 & 3.11 & 203.41 & 9.22 & 235.67 & -234.07 & -30.66 \\
\hline $10 \mathrm{MB} 0093$ & 37.8730000 & -119.0401670 & 2164.6 & 979320.4 & 979980.96 & 667.66 & -242.215 & -1.514 & 0.08 & 3.01 & 3.09 & 203.47 & 7.07 & -235.15 & -233.57 & -30.1 \\
\hline 10MB0094 & 37.8890000 & -119.0415000 & 2128.57 & 979326.3 & 979982.37 & 656.56 & -238.183 & -1.516 & 0.22 & 2.88 & 3.1 & & 0.51 & & -236.09 & -32.51 \\
\hline 10MB0095 & 37.8970000 & -119.0416670 & 2114.09 & 979328.7 & 979983.07 & 652.09 & -236.563 & -1.516 & 1.11 & 2.77 & 3.88 & 203.59 & -2.28 & -238.84 & -236.48 & -32.89 \\
\hline 10MB0096 & 37.9055000 & -119.0430000 & 2097.57 & 979331.7 & 979983.81 & 647 & -234.715 & -1.517 & 1.01 & 2.67 & 3.68 & 203.61 & -5.13 & & & -34.07 \\
\hline 10MB0097 & 37.9230000 & -119.0463330 & 2078.46 & 979331.7 & 979985.34 & 641.11 & -232.576 & -1.517 & 0.18 & 2.54 & 2.72 & 203.58 & -12.56 & -245.14 & -243.94 & -40.36 \\
\hline 10MB0098 & 37.9315000 & -119.0513330 & 2056.06 & 979333.4 & 979986.09 & 634.2 & -230.069 & -1.517 & 0.29 & 2.53 & 2.82 & 203.59 & -18.54 & & -247.3 & -43.71 \\
\hline 10MB0099 & 37.9463330 & -119.0693330 & 1978.15 & 979348.9 & 979987.39 & 610.18 & -221.352 & -1.514 & 0.27 & 3 & 3.27 & 203.64 & -28.36 & & & -44.31 \\
\hline $10 \mathrm{MB} 0100$ & 86670 & -119.0700000 & 2090.47 & 979336.6 & 979982.34 & 644.81 & -233.92 & -1.517 & 0.01 & 3.18 & 3.19 & 203.41 & -0.93 & & & -29.77 \\
\hline 10MB0101 & 37.8828330 & -119.0666670 & 2092.7 & 979334.7 & 979981.82 & 645.5 & -234.169 & -1.517 & 0.02 & 3.2 & 3.22 & 203.47 & -1.64 & 235.81 & -234.11 & -30.64 \\
\hline 10MB0102 & 37.8831670 & -119.0486670 & 2132.69 & 979326.2 & 979981.85 & 657.82 & -238.644 & -1.516 & 0.07 & 2.89 & 2.96 & 03.51 & 2.22 & & -234.98 & -31.47 \\
\hline $10 \mathrm{MB} 0103$ & 1670 & -119 & 2115.37 & 979329.2 & 979982.64 & 652.49 & -236.706 & -1.516 & 0.16 & 2.84 & 3 & 203.59 & -0.93 & & & -32.56 \\
\hline 10MB0104 & 37.8941670 & 23330 & 2241.86 & 979299.8 & 979982.82 & 691.48 & -250.861 & -1.507 & 2.91 & 2.56 & 5.47 & 203.37 & 8.48 & & 8.42 & -35.05 \\
\hline $10 \mathrm{MB} 0105$ & 8330 & 3330 & 76.55 & 979315.3 & 979982.79 & 671.35 & & -1.513 & 2.05 & 2.64 & 4.69 & .49 & 3.81 & & & -33 \\
\hline 10MB0106 & 37.8780000 & -119.0281670 & 2177.13 & 979314.5 & 979981.4 & 671.53 & -243.616 & -1.513 & 1.03 & 3.02 & 4.05 & 03.53 & 4.66 & & & -32.89 \\
\hline 10MB0 107 & 8330 & -119 & 2205.99 & 979308.6 & 979980.77 & 680.42 & -246.846 & -1.511 & 2.09 & 2.93 & 5.02 & 03.47 & 8.28 & & & -31.59 \\
\hline $10 \mathrm{MB} 0108$ & 8330 & -119 & 2195.72 & 979312.5 & 979980.42 & 677.26 & -245.697 & -1.512 & 0.47 & 3.13 & 3.6 & 203.46 & 9.38 & & 4.23 & -30.77 \\
\hline 10MB0109 & & 43330 & 217.12 & 979306.6 & 979980.42 & 683.85 & -248.091 & -1.51 & 95 & 2.93 & 4.88 & 03.47 & 10.02 & & -234.7 & -31.23 \\
\hline $10 \mathrm{MB} 0110$ & 37.8590000 & -119.0213330 & 2285.76 & 979292.5 & 979979.74 & 705.01 & -255.772 & -1.501 & 3.22 & 2.64 & 5.86 & 03.33 & 17.78 & -237.99 & & -30.3 \\
\hline $10 \mathrm{MB} 0111$ & & & 239.64 & 979302.2 & 979979.72 & 690.8 & 0.612 & -1.507 & 1.48 & 2.89 & 4.37 & 203.42 & 13.31 & & & -31.02 \\
\hline 10MB0112 & 37.8555000 & 51670 & 2265.24 & 979295.8 & 979979.43 & 698.69 & -253.477 & -1.504 & 2.8 & 2.75 & 5.55 & 203.36 & 15.02 & -238.46 & -234.41 & -31.05 \\
\hline $10 \mathrm{MB} 0113$ & & -119.04 & 07.28 & 979290.5 & 979978.16 & 711.65 & -258.18 & -1.498 & 0.47 & 2.77 & 3.24 & 03.12 & 23.98 & & -232.46 & -29.34 \\
\hline $10 \mathrm{MB} 0114$ & 7.8356670 & -119.0488330 & 67.53 & 979277.3 & 979977.69 & 730.22 & -264.923 & -1.486 & 86 & 2.82 & 3.68 & 02.91 & 29.84 & -235.08 & -232.89 & -29.98 \\
\hline 10MB0115 & 5000 & & 5.97 & 979268.8 & 979977.5 & 745.15 & 0.342 & -1.475 & 1.45 & 3 & 4.45 & 73 & 42 & & & -28.22 \\
\hline $10 \mathrm{MB} 011$ & 6670 & & 21.39 & 979286.2 & 979976.64 & 716 & -259.759 & -1.495 & 0. & 3 & 3.21 & 202.85 & 25.59 & & -232.45 & -29.6 \\
\hline 10MB0117 & 37.8075000 & -119.0583330 & 2335.23 & 979280.7 & 979975.22 & 720.27 & -261.308 & -1.493 & 0.35 & 3.44 & 3.79 & 02.65 & 25.74 & .57 & 233.27 & -30.62 \\
\hline $10 \mathrm{MB} 0118$ & 37.8031670 & -119.0646670 & 2341.23 & 979280.3 & 979974.85 & 722.12 & -261.979 & -1.492 & 78 & 3.74 & 4.52 & 202.49 & 27.57 & 234.41 & 231.38 & -28.89 \\
\hline 10MB0119 & & & 44.34 & 979278.5 & 979 & 723.08 & 2.327 & -1.491 & & 93 & 4.28 & & & & & -30.33 \\
\hline 10MB012 & 1670 & & 37.51 & 979281.1 & 979974.85 & 720.97 & -261.563 & -1.492 & & 4.08 & 4.92 & 202.32 & 27.2 & & 94 & -28.62 \\
\hline $10 \mathrm{MB} 0121$ & 081670 & 19.0780000 & 39.25 & 979281.2 & 979975.28 & 721.51 & -261.758 & -1.492 & 81 & 3.91 & 4.72 & 202.37 & 27.42 & 34 & 231.11 & -28.74 \\
\hline $10 \mathrm{MB} 0122$ & 7.8145000 & -119.0786670 & 45.41 & 979281 & 979975.84 & 723.4 & -262.447 & -1.491 & 0.47 & 3.75 & 4.22 & 202.4 & 28.58 & 233.87 & 231.14 & -28.74 \\
\hline $10 \mathrm{MB} 0123$ & & & 98.74 & 979290.6 & 979976.48 & & & -1.499 & 0.6 & 3.8 & 4.4 & 202.53 & 16 & & & -28.63 \\
\hline $10 \mathrm{MB} 01$ & & & 80.48 & & & & & & 0.38 & & 4.02 & & & & & -28.87 \\
\hline $10 \mathrm{MB} 0125$ & 346670 & -119.0770000 & 46.22 & 979301.9 & 979977.6 & 692.83 & -251.348 & -1.506 & 0.4 & 65 & 4.05 & 02.77 & 17.15 & -23 & -231.66 & -28.89 \\
\hline $10 \mathrm{MB} 0126$ & 37.8993330 & -118.9798330 & 2140.98 & 979323.7 & 979983.27 & 660.38 & -239.571 & -1.515 & 0.28 & 2.45 & 2.73 & 203.66 & 0.84 & -238.74 & -237.52 & -33.86 \\
\hline $10 \mathrm{MB} 0127$ & 37.8730000 & & 2353.24 & 979280.5 & 979980.96 & 725.82 & -263.323 & -1.489 & 0.91 & 2.42 & 3.33 & 03.33 & 25.33 & & -236.15 & -32.82 \\
\hline $10 \mathrm{MB} 0128$ & & & 96.64 & 979272 & & & & & & 2.48 & 3.35 & & & & 5.4 & -32.14 \\
\hline $10 \mathrm{MB} 0129$ & & & 124.93 & 979266.5 & 979979. & & & -1.4 & & & 3.06 & 21 & 34.68 & & & -31.86 \\
\hline $10 \mathrm{MB} 0130$ & 37.8510000 & 8.9911670 & 2427.98 & 979265.5 & 979979.04 & 748.86 & -271.686 & -1.472 & 1.04 & 2.41 & 3.45 & 203.2 & 35.3 & 236.39 & -234.41 & -31.21 \\
\hline 10MB0131 & 7.8465000 & -118.9913330 & 2425.23 & 979267.1 & 979978.64 & 748.01 & -271.379 & -1.473 & 0.96 & 2.36 & 3.32 & 203.22 & 36.47 & -234.91 & -233.07 & -29.85 \\
\hline & & & 03.59 & 979269.2 & 979977.94 & & -268.958 & -1.478 & 1.33 & 2. & 3.61 & 3.27 & 32.58 & & -234.25 & -30.98 \\
\hline & & & & & & & -269.51 & -1.477 & 1.1 & & 3.41 & 03.17 & 33.63 & & -233.95 & -30.78 \\
\hline 10MB0134 & 37.8221670 & -119.0090000 & 2362.81 & 979280.4 & 979976.51 & 728.77 & -264.394 & -1.487 & 1.29 & 2.39 & 3.68 & 203.19 & 32.61 & -231.78 & -229.59 & -26.4 \\
\hline
\end{tabular}




\begin{tabular}{|c|c|c|c|c|c|c|c|c|c|c|c|c|c|c|c|c|}
\hline ID & LAT & LONG & |ELEV_M| & OG & TG & FAC & $\mathrm{BC}$ & $\mathrm{CC}$ & ITC & OTC & TTC | & |TISOC & FAA & SBA & CBA & ISO \\
\hline $10 \mathrm{MB} 0135$ & 37.8223330 & -118.9826670 & 2427.88 & 979266.3 & 979976.52 & 748.83 & -271.676 & -1.472 & 0.09 & 2.2 & 2.29 & 203.22 & 38.63 & -233.05 & -232.23 & -29.01 \\
\hline $10 \mathrm{MB} 0136$ & 37.8386670 & -118.9838330 & 2413.16 & 979271.4 & 979977.95 & 744.29 & -270.029 & -1.476 & 0.16 & 2.26 & 2.42 & 203.26 & 37.77 & -232.26 & -231.31 & -28.05 \\
\hline 10MB0137 & 37.8545000 & -118.9801670 & 2431.08 & 979268.2 & 979979.34 & 749.81 & -272.034 & -1.472 & 0.2 & 2.42 & 2.62 & 203.24 & 38.69 & -233.35 & -232.2 & -28.96 \\
\hline $10 \mathrm{MB} 0138$ & 37.8606670 & -118.9785000 & 2390.94 & 979275.6 & 979979.88 & 737.44 & -267.542 & -1.481 & 0.44 & 2.39 & 2.83 & 203.32 & 33.12 & -234.42 & -233.07 & -29.75 \\
\hline $10 \mathrm{MB} 0139$ & 37.8666670 & -118.9753330 & 2328.37 & 979287.7 & 979980.41 & 718.15 & -260.54 & -1.494 & 0.29 & 2.34 & 2.63 & 203.44 & 25.42 & -235.12 & -233.99 & -30.55 \\
\hline $10 \mathrm{MB} 0140$ & 37.8731670 & -118.9753330 & 2300.84 & 979293.3 & 979980.98 & 709.67 & -257.46 & -1.499 & 0.25 & 2.36 & 2.61 & 203.43 & 21.99 & -235.47 & -234.36 & -30.93 \\
\hline $10 \mathrm{MB} 0141$ & 37.8806670 & -118.9725000 & 2255.03 & 979304.5 & 979981.63 & 695.54 & -252.334 & -1.505 & 0.22 & 2.33 & 2.55 & 203.53 & 18.44 & -233.89 & -232.85 & -29.32 \\
\hline $10 \mathrm{MB} 0142$ & 37.8946670 & -118.9728330 & 2178.01 & 979317.8 & 979982.86 & 671.8 & -243.715 & -1.513 & 0.18 & 2.32 & 2.5 & 203.58 & 6.7 & -237.01 & -236.03 & -32.45 \\
\hline $10 \mathrm{MB} 0143$ & 37.8803330 & -118.9611670 & 2268.84 & 979302 & 979981.61 & 699.8 & -253.879 & -1.503 & 0.1 & 2.16 & 2.26 & 203.51 & 20.17 & -233.71 & -232.95 & -29.44 \\
\hline $10 \mathrm{MB} 0144$ & 37.8733330 & -118.9660000 & 2294.11 & 979296.6 & 979980.99 & 707.59 & -256.707 & -1.5 & 0.09 & 2.22 & 2.31 & 203.48 & 23.23 & -233.47 & -232.66 & -29.18 \\
\hline $10 \mathrm{MB} 0145$ & 37.8655000 & -118.9670000 & 2317.82 & 979290.4 & 979980.31 & 714.9 & -259.36 & -1.496 & 0.12 & 2.23 & 2.35 & 203.46 & 25 & -234.36 & -233.51 & -30.05 \\
\hline $10 \mathrm{MB} 0146$ & 37.8581670 & -118.9643330 & 2348.85 & 979283.9 & 979979.66 & 724.46 & -262.832 & -1.49 & 0.17 & 2.17 & 2.34 & 203.42 & 28.69 & -234.14 & -233.29 & -29.87 \\
\hline $10 \mathrm{MB} 0147$ & 37.8515000 & -118.9583330 & 2372.78 & 979279.3 & 979979.08 & 731.84 & -265.509 & -1.485 & 0.19 & 2.12 & 2.31 & 203.42 & 32.11 & -233.4 & -232.58 & -29.16 \\
\hline $10 \mathrm{MB} 0148$ & 37.8448330 & -118.9513330 & 2393.02 & 979274.5 & 979978.49 & 738.08 & -267.774 & -1.481 & 0.06 & 2.13 & 2.19 & 203.43 & 34.04 & -233.73 & -233.03 & -29.6 \\
\hline $10 \mathrm{MB} 0149$ & 37.8398330 & -118.9521670 & 2398.11 & 979272.9 & 979978.06 & 739.65 & -268.344 & -1.48 & 0.1 & 2.13 & 2.23 & 203.42 & 34.52 & -233.83 & -233.08 & -29.66 \\
\hline $10 \mathrm{MB} 0150$ & 37.8315000 & -118.9595000 & 2452.21 & 979262.4 & 979977.33 & 756.33 & -274.398 & -1.466 & 0.19 & 2.19 & 2.38 & 203.28 & 41.43 & -232.96 & -232.05 & -28.77 \\
\hline 10MB0151 & 37.8243330 & -118.9578330 & 2445.41 & 979263.4 & 979976.7 & 754.23 & -273.637 & -1.468 & 0.16 & 2.16 & 2.32 & 203.28 & 40.92 & -232.72 & -231.87 & -28.59 \\
\hline $10 \mathrm{MB} 0152$ & 37.8023330 & -118.9671670 & 2438.7 & 979266.4 & 979974.77 & 752.16 & -272.887 & -1.47 & 0.12 & 2.17 & 2.29 & 203.24 & 43.79 & -229.1 & -228.28 & -25.04 \\
\hline $10 \mathrm{MB} 0153$ & 37.7936670 & -118.9718330 & 2469.03 & 979257.5 & 979974.01 & 761.51 & -276.28 & -1.462 & 0.12 & 2.3 & 2.42 & 203.11 & 44.96 & -231.33 & -230.37 & -27.26 \\
\hline $10 \mathrm{MB} 0154$ & 37.7976670 & -118.9753330 & 2483.42 & 979258.9 & 979974.36 & 765.95 & -277.89 & -1.457 & 0.22 & 2.34 & 2.56 & 203.09 & 50.52 & -227.37 & -226.27 & -23.18 \\
\hline $10 \mathrm{MB} 0155$ & 37.7980000 & -118.9891670 & 2489.39 & 979263.5 & 979974.39 & 767.79 & -278.559 & -1.456 & 0.18 & 2.4 & 2.58 & 203.01 & 56.9 & -221.66 & -220.53 & -17.52 \\
\hline $10 \mathrm{MB} 0156$ & 37.7916670 & -119.0043330 & 2425.42 & 979266.9 & 979973.84 & 748.07 & -271.4 & -1.473 & 0.16 & 2.43 & 2.59 & 202.99 & 41.12 & -230.28 & -229.17 & -26.18 \\
\hline $10 \mathrm{MB} 0157$ & 37.7855000 & -119.0048330 & 2431.27 & 979264.7 & 979973.3 & 749.87 & -272.055 & -1.472 & 0.09 & 2.52 & 2.61 & 202.92 & 41.26 & -230.8 & -229.66 & -26.74 \\
\hline $10 \mathrm{MB} 0158$ & 37.7786670 & -119.0088330 & 2440.9 & 979260.8 & 979972.7 & 752.84 & -273.132 & -1.469 & 0.06 & 2.69 & 2.75 & 202.78 & 40.99 & -232.15 & -230.86 & -28.08 \\
\hline 10MB0159 & 37.7678330 & -119.0228330 & 2473.57 & 979246.9 & 979971.75 & 762.91 & -276.789 & -1.46 & 0.73 & 3.29 & 4.02 & 202.46 & 38.05 & -238.74 & -236.18 & -33.72 \\
\hline $10 \mathrm{MB} 0160$ & 37.7655000 & -119.0265000 & 2498.11 & 979241.4 & 979971.55 & 770.48 & -279.534 & -1.453 & 1.36 & 3.38 & 4.74 & 202.35 & 40.3 & -239.23 & -235.94 & -33.59 \\
\hline $10 \mathrm{MB} 0161$ & 37.7611670 & -119.0268330 & 2533.89 & 979232.7 & 979971.17 & 781.51 & -283.538 & -1.442 & 1.6 & 3.45 & 5.05 & 202.22 & 43,01 & -240.52 & -236.92 & -34.7 \\
\hline $10 \mathrm{MB} 0162$ & 37.7585000 & -119.0271670 & 2536.85 & 979231 & 979970.93 & 782.42 & -283.869 & -1.441 & 2.59 & 3.51 & 6.1 & 202.19 & 42.47 & -241.4 & -236.74 & -34.55 \\
\hline $10 \mathrm{MB} 0163$ & 37.7556670 & -119.0243330 & 2527.1 & 979232.7 & 979970.69 & 779.41 & -282.778 & -1.444 & 1.69 & 3.5 & 5.19 & 202.19 & 41.45 & -241.33 & -237.58 & -35.39 \\
\hline $10 \mathrm{MB} 0164$ & 37.7521670 & -119.0273330 & 2520.09 & 979234.5 & 979970.38 & 777.25 & -281.993 & -1.446 & 3.96 & 3.61 & 7.57 & 202.11 & 41.33 & -240.67 & -234.54 & -32.43 \\
\hline $10 \mathrm{MB} 0165$ & 37.7490000 & -119.0233330 & 2494.48 & 979238.4 & 979970.1 & 769.36 & -279.128 & -1.454 & 1.94 & 3.57 & 5.51 & 202.18 & 37.62 & -241.51 & -237.45 & -35.27 \\
\hline 10MB0166 & 37.7485000 & -119.0168330 & 2488.94 & 979239.6 & 979970.06 & 767.65 & -278.508 & -1.456 & 1.4 & 3.44 & 4.84 & 202.28 & 37.2 & -241.31 & -237.93 & -35.65 \\
\hline 10MB0167 & 37.9440000 & -119.0961670 & 2055.42 & 979348.8 & 979987.19 & 634 & -229.998 & -1.517 & 0.18 & 3.78 & 3.96 & 203.38 & -4.38 & -234.38 & -231.93 & -28.55 \\
\hline $10 \mathrm{MB} 0168$ & 37.9445000 & -119.0900000 & 2029.85 & 979349.8 & 979987.23 & 626.12 & -227.136 & -1.516 & 0.3 & 3.55 & 3.85 & 203.46 & -11.28 & -238.41 & -236.08 & -32.62 \\
\hline 10MB0169 & 37.9440000 & -119.0806670 & 1974.59 & 979356.4 & 979987.19 & 609.08 & -220.953 & -1.514 & 0.18 & 3.48 & 3.66 & 203.6 & -21.69 & -242.64 & -240.5 & -36.9 \\
\hline $10 \mathrm{MB} 0170$ & 37.9425000 & -119.0703330 & 2004.09 & 979345.2 & 979987.05 & 618.18 & -224.254 & -1.515 & 0.19 & 2.94 & 3.13 & 203.59 & -23.7 & -247.96 & -246.34 & -42.75 \\
\hline LEEVIN & 37.9556670 & -119.1190000 & 2071.09 & 979348.3 & 979988.21 & 638.83 & -231.751 & -1.517 & 1.89 & 5.47 & 7.36 & 203.15 & -1.07 & -232.82 & -226.98 & -23.83 \\
\hline $10 \mathrm{MB} 1001$ & 37.8871670 & -119.0888330 & 2098.64 & 979337.5 & 979982.2 & 647.33 & -234.834 & -1.517 & 0.02 & 3.76 & 3.78 & 203.26 & 2.65 & -232.18 & -229.92 & -26.66 \\
\hline $10 \mathrm{MB} 1002$ & 37.8891670 & -119.0850000 & 2093.55 & 979338.4 & 979982.38 & 645.76 & -234.264 & -1.517 & 0.01 & 3.6 & 3.61 & 203.3 & 1.76 & -232.5 & -230.41 & -27.11 \\
\hline $10 \mathrm{MB} 1003$ & 37.8911670 & -119.0815000 & 2089.19 & 979339 & 979982.55 & 644.42 & -233.777 & -1.517 & 0.01 & 3.47 & 3.48 & 203.34 & 0.88 & -232.9 & -230.94 & -27.6 \\
\hline $10 \mathrm{MB} 1004$ & 37.8931670 & -119.0778330 & 2085.35 & 979339.5 & 979982.73 & 643.23 & -233.347 & -1.517 & 0.01 & 3.36 & 3.37 & 203.36 & 0.04 & -233.31 & -231.46 & -28.1 \\
\hline $10 \mathrm{MB} 1005$ & 37.8951670 & -119.0743330 & 2083.58 & 979339.5 & 979982.91 & 642.69 & -233.149 & -1.517 & 0.01 & 3.23 & 3.24 & 203.4 & -0.74 & -233.89 & -232.17 & -28.77 \\
\hline 10MB1006 & 37.8975000 & -119.0706670 & 2081.39 & 979339.5 & 979983.11 & 642.01 & -232.904 & -1.517 & 0.02 & 3.13 & 3.15 & 203.45 & -1.63 & -234.53 & -232.9 & -29.45 \\
\hline $10 \mathrm{MB} 1007$ & 37.8995000 & -119.0673330 & 2081.24 & 979339.2 & 979983.29 & 641.96 & -232.887 & -1.517 & 0.02 & 3.01 & 3.03 & 203.49 & -2.09 & -234.97 & -233.46 & -29.97 \\
\hline $10 \mathrm{MB} 1008$ & 37.9021670 & -119.0630000 & 2080.23 & 979338.9 & 979983.52 & 641.65 & -232.774 & -1.517 & 0.02 & 2.93 & 2.95 & 203.53 & -2.98 & -235.76 & -234.32 & -30.79 \\
\hline
\end{tabular}




\begin{tabular}{|c|c|c|c|c|c|c|c|c|c|c|c|c|c|c|c|c|}
\hline ID & LAT & LONG & $\mid$ ELEV_M & OG & TG & FAC & $\mathrm{BC}$ & $\mathrm{CC}$ & ITC & OTC 1 & TTC $\mid$ & TISOC| & FAA & SBA & CBA & ISO \\
\hline 10MB1009 & 37.9045000 & -119.0595000 & 2080.32 & 979338.1 & 979983.72 & 641.68 & -232.784 & -1.517 & 0.03 & 2.87 & 2.9 & 203.54 & -3.92 & -236.7 & -235.32 & -31.78 \\
\hline $10 \mathrm{MB} 1010$ & 37.9066670 & -119.0560000 & 2081.51 & 979336.9 & 979983.91 & 642.05 & -232.917 & -1.517 & 0.06 & 2.81 & 2.87 & 203.56 & -4.93 & -237.85 & -236.5 & -32.94 \\
\hline 10MB1011 & 37.9091670 & -119.0521670 & 2083.92 & 979335.7 & 979984.13 & 642.79 & -233.187 & -1.517 & 0.15 & 2.74 & 2.89 & 203.57 & -5.68 & -238.86 & -237.49 & -33.92 \\
\hline $10 \mathrm{MB} 1012$ & 37.9113330 & -119.0491670 & 2087.58 & 979333.9 & 979984.32 & 643.92 & -233.596 & -1.517 & 0.24 & 2.66 & 2.9 & 203.58 & -6.5 & -240.1 & -238.71 & -35.13 \\
\hline $10 \mathrm{MB} 1013$ & 37.9140000 & -119.0456670 & 2088.92 & 979332.2 & 979984.56 & 644.33 & -233.746 & -1.517 & 0.41 & 2.6 & 3.01 & 203.57 & -8.01 & -241.76 & -240.26 & -36.69 \\
\hline 10MB1014 & 37.9171670 & -119.0431670 & 2093.49 & 979329.6 & 979984.83 & 645.74 & -234.258 & -1.517 & 0.51 & 2.54 & 3.05 & 203.55 & -9.45 & -243.71 & -242.17 & -38.62 \\
\hline $10 \mathrm{MB} 1015$ & 37.9201670 & -119.0401670 & 2082.88 & 979329.9 & 979985.1 & 642.47 & -233.071 & -1.517 & 0.75 & 2.51 & 3.26 & 203.58 & -12.77 & -245.84 & -244.1 & -40.52 \\
\hline 10MB1016 & 37.9223330 & -119.0365000 & 2079.68 & 979328.6 & 979985.29 & 641.48 & -232.713 & -1.517 & 1.07 & 2.47 & 3.54 & 203.59 & -15.18 & -247.89 & -245.87 & -42.28 \\
\hline $10 \mathrm{MB1017}$ & 37.9246670 & -119.0330000 & 2070.08 & 979328.7 & 979985.49 & 638.52 & -231.638 & -1.517 & 0.85 & 2.43 & 3.28 & 203.62 & -18.28 & -249.92 & -248.16 & -44.54 \\
\hline $10 \mathrm{MB} 1018$ & 37.9245000 & -119.0285000 & 2042.04 & 979334.1 & 979985.48 & 629.88 & -228.5 & -1.517 & 1.25 & 2.49 & 3.74 & 203.69 & -21.51 & -250.01 & -247.79 & -44.1 \\
\hline $10 \mathrm{MB} 1019$ & 37.9265000 & -119.0230000 & 2008.45 & 979340.1 & 979985.65 & 619.52 & -224.742 & -1.516 & 0.81 & 2.57 & 3.38 & 203.76 & -26.03 & -250.77 & -248.9 & -45.14 \\
\hline $10 \mathrm{MB} 1020$ & 37.9281670 & -119.0190000 & 1994.37 & 979342.3 & 979985.8 & 615.18 & -223.166 & -1.515 & 0.4 & 2.58 & 2.98 & 203.79 & -28.34 & -251.51 & -250.04 & -46.25 \\
\hline 10MB1021 & 37.9291670 & -119.0145000 & 1989.28 & 979342.8 & 979985.89 & 613.61 & -222.597 & -1.515 & 0.22 & 2.56 & 2.78 & 203.79 & -29.47 & -252.07 & -250.8 & -47.01 \\
\hline 10MB1022 & 37.9313330 & -119.0106670 & 1986.56 & 979342.9 & 979986.08 & 612.77 & -222.293 & -1.514 & 0.09 & 2.47 & 2.56 & 203.79 & -30.45 & -252.74 & -251.69 & -47.9 \\
\hline $10 \mathrm{MB1} 023$ & 37.9340000 & -119.0073330 & 1987.2 & 979342 & 979986.31 & 612.97 & -222.365 & -1.514 & 0.1 & 2.35 & 2.45 & 203.8 & -31.33 & -253.7 & -252.76 & -48.96 \\
\hline $10 \mathrm{MB1024}$ & 37.9340000 & -119.0036670 & 1977.73 & 979344.5 & 979986.31 & 610.05 & -221.304 & -1.514 & 0.07 & 2.36 & 2.43 & 203.8 & -31.73 & -253.03 & -252.11 & -48.31 \\
\hline $10 \mathrm{MB} 1025$ & 37.9333330 & -118.9991670 & 1975.01 & 979345.7 & 979986.25 & 609.21 & -221 & -1.514 & 0.06 & 2.36 & 2.42 & 203.82 & -31.29 & -252.29 & -251.39 & -47.57 \\
\hline 10MB1026 & 37.9331670 & -118.9945000 & 1982.18 & 979344.8 & 979986.24 & 611.42 & -221.802 & -1.514 & 0.07 & 2.28 & 2.35 & 203.8 & -30.02 & -251.82 & -250.99 & -47.19 \\
\hline $10 \mathrm{MB} 1027$ & 37.9331670 & -118.9900000 & 1989.58 & 979344.3 & 979986.24 & 613.7 & -222.631 & -1.515 & 0.08 & 2.21 & 2.29 & 203.77 & -28.25 & -250.88 & -250.1 & -46.33 \\
\hline $10 \mathrm{MB1028}$ & 37.9330000 & -118.9856670 & 1995.5 & 979344.4 & 979986.22 & 615.53 & -223.292 & -1.515 & 0.07 & 2.14 & 2.21 & 203.75 & -26.27 & -249.56 & -248.87 & -45.12 \\
\hline 10MB1029 & 37.9330000 & -118.9806670 & 2001.5 & 979345 & 979986.22 & 617.38 & -223.964 & -1.515 & 0.08 & 2.1 & 2.18 & 203.71 & -23.83 & -247.79 & -247.13 & -43.42 \\
\hline $10 \mathrm{MB} 1030$ & 37.93 & -118.9750000 & 2015.34 & 979343.7 & 979986.27 & 621.64 & -225.513 & -1.516 & 14 & 2.02 & 2.16 & 203.69 & -20.96 & -246.47 & -245.82 & -42.13 \\
\hline 10MB1031 & 37.9356670 & -118.9715000 & 2027.56 & 979341.1 & 979986.46 & 625.41 & -226.88 & -1.516 & 0.18 & 1.93 & 2.11 & 203.61 & -19.99 & -246.87 & -246.27 & -42.66 \\
\hline $10 \mathrm{MB} 1032$ & 37.9363330 & -118.9665000 & 2035.03 & 979340.7 & 979986.51 & 627.72 & -227.716 & -1.516 & 0.09 & 1.89 & 1.98 & 203.63 & -18.07 & -245.79 & -245.33 & -41.7 \\
\hline 10MB1033 & 37.9358330 & -118.9618330 & 2035.76 & 979342.5 & 979986.47 & 627.94 & -227.798 & -1.516 & 0.06 & 1.9 & 1.96 & 203.64 & -16.06 & -243.86 & -243.42 & -39.78 \\
\hline 10MB1034 & 37.9366670 & -118.9571670 & 2039.57 & 979343.2 & 979986.54 & 629.12 & -228.224 & -1.517 & 05 & 1.89 & 1.94 & 203.62 & -14.24 & -242.47 & -242.04 & -38.42 \\
\hline $10 \mathrm{MB} 1035$ & 37.9373330 & -118.9536670 & 2037.86 & 979344.4 & 979986.6 & 628.59 & -228.033 & -1.517 & 0.05 & 1.88 & 1.93 & 203.6 & -13.6 & -241.63 & -241.22 & -37.62 \\
\hline 10MB1036 & 37.9383330 & -118.9478330 & 2038.96 & 979345.5 & 979986.69 & 628.93 & -228.156 & -1.517 & 0.04 & 1.88 & 1.92 & 203.58 & -12.28 & -240.43 & -240.03 & -36.45 \\
\hline 10MB1037 & 37.9390000 & -118.9435000 & 2040.79 & 979345.8 & 979986.75 & 629.49 & -228.361 & -1.517 & 0.05 & 1.88 & 1.93 & 203.56 & -11.41 & -239.77 & -239.36 & -35.8 \\
\hline 10MB1038 & 37.9338330 & -118.9386670 & 2063.83 & 979343.5 & 979986.29 & 636.6 & -230.939 & -1.517 & 0.1 & 1.92 & 2.02 & 3.52 & -6.16 & -237.1 & -236.6 & -33.08 \\
\hline 10MB1039 & 37.927 & -118.9408330 & 2083.09 & 979339.3 & 979985.71 & 642.54 & -233.095 & -1.517 & & 1.97 & 2.1 & 3.53 & -3.88 & & .39 & -32.86 \\
\hline $10 \mathrm{MB} 1040$ & 37.9215000 & -118.9440000 & 2103.79 & 979334.3 & 979985.21 & 648.92 & -235.41 & -1.517 & 0.13 & 1.98 & 2.11 & 203.54 & -1.98 & -237.39 & -236.8 & -33.26 \\
\hline 10MB1041 & 37.9055000 & -118.9528330 & 2158.62 & 979323.6 & 979983.81 & 665.82 & -241.546 & -1.514 & 0.15 & 2.06 & 2.21 & 203.58 & 5.63 & -235.92 & -235.23 & -31.65 \\
\hline $10 \mathrm{MB1042}$ & 37.8981670 & -118.9570000 & 2197.76 & 979317 & 979983.17 & 677.89 & -245.925 & -1.511 & 0.17 & 2.06 & 2.23 & 203.56 & 11.74 & -234.18 & -233.46 & -29.9 \\
\hline $10 \mathrm{MB} 1043$ & & & 2189.62 & 979317.9 & 979983.02 & 675.38 & -245.015 & -1.512 & 17 & 2.12 & 2.29 & 203.6 & 10.28 & & -233.96 & -30.36 \\
\hline $10 \mathrm{MB} 1044$ & 37.9040000 & 18.9620000 & 8.14 & 979325 & 979983.68 & 662.59 & -240.373 & -1.515 & & 2.1 & 2.27 & 203.61 & 3.89 & -236.48 & -235.72 & -32.11 \\
\hline $10 \mathrm{MB} 1045$ & 37.9110000 & -118.9575000 & 2117.32 & 979330.7 & 979984.29 & 653.09 & -236.925 & -1.516 & 0.15 & 2.08 & 2.23 & 203.61 & -0.52 & -237.44 & -236.73 & -33.12 \\
\hline 10MB1046 & 37.9180000 & -118.9553330 & 2086.97 & 979336.7 & 979984.91 & 643.73 & -233.528 & -1.517 & 0.13 & 2.06 & 2.19 & 203.61 & -4.49 & -238.02 & -237.35 & -33.74 \\
\hline 10MB1047 & 37.9253330 & -118.9550000 & 2067.67 & 979339.9 & 979985.55 & 637.78 & -231.369 & -1.517 & 0.07 & 1.99 & 2.06 & 203.61 & -7.82 & -239.19 & -238.65 & -35.04 \\
\hline $10 \mathrm{MB1048}$ & 37.9315000 & -118.9546670 & 2050.97 & 979343 & 979986.09 & 632.63 & -229.5 & -1.517 & 0.05 & 1.94 & 1.99 & 203.61 & -10.45 & -239.95 & -239.48 & -35.87 \\
\hline & 37.9258330 & & 2028.84 & 979340.4 & 979985.59 & 625.81 & -227.024 & -1.516 & 0.1 & 2.17 & 2.27 & 203.73 & -19.42 & -246.44 & -245.69 & -41.96 \\
\hline 10MB1050 & 37.9225000 & -118.9888330 & 2029.57 & 979337.8 & 979985.3 & 626.03 & -227.105 & -1.516 & 0.14 & 2.33 & 2.47 & 203.73 & -21.45 & -248.56 & -247.6 & -43.87 \\
\hline 10MB1051 & 37.9195000 & -118.9986670 & 2030.36 & 979336 & 979985.04 & 626.28 & -227.194 & -1.516 & 0.36 & 2.55 & 2.91 & 203.73 & -22.76 & -249.95 & -248.56 & -44.83 \\
\hline $10 \mathrm{MB} 1052$ & 38.0453330 & -119.1588330 & 2100.44 & 979356.9 & 979996.08 & 647.88 & -235.035 & -1.517 & 0.09 & 5.32 & 5.41 & 202.65 & 8.7 & -226.34 & -222.44 & -19.79 \\
\hline $10 \mathrm{MB} 1053$ & 38.0468330 & -119.1536670 & 2088.15 & 979359.7 & 979996.21 & 644.09 & -233.661 & -1.517 & 0.07 & 4.84 & 4.91 & 202.71 & 7.59 & -226.07 & -222.68 & -19.97 \\
\hline
\end{tabular}




\begin{tabular}{|c|c|c|c|c|c|c|c|c|c|c|c|c|c|c|c|c|}
\hline ID & LAT & LONG & $\mid$\begin{tabular}{|l|} 
ELEV_M \\
\end{tabular} & \begin{tabular}{|l|}
$\mathrm{OG}$ \\
\end{tabular} & TG & \begin{tabular}{l|} 
FAC \\
\end{tabular} & $\mathrm{BC}$ & CC & ITC & OTC 1 & TTC 1 & TISOC| & \begin{tabular}{|l|} 
FAA \\
\end{tabular} & SBA & CBA & ISO \\
\hline $10 \mathrm{MB1} 009$ & 37.9045000 & -119.0595000 & 2080.32 & 979338.1 & 979983.72 & 641.68 & -232.784 & -1.517 & 0.03 & 2.87 & 2.9 & 203.54 & -3.92 & -236.7 & -235.32 & -31.78 \\
\hline $10 \mathrm{MB} 1010$ & 37.9066670 & -119.0560000 & 2081.51 & 979336.9 & 979983.91 & 642.05 & -232.917 & -1.517 & 0.06 & 2.81 & 2.87 & 203.56 & -4.93 & -237.85 & -236.5 & -32.94 \\
\hline $10 \mathrm{MB1} 11$ & 37.9091670 & -119.0521670 & 2083.92 & 979335.7 & 979984.13 & 642.79 & -233.187 & -1.517 & 0.15 & 2.74 & 2.89 & 203.57 & -5.68 & -238.86 & -237.49 & -33.92 \\
\hline $10 \mathrm{MB} 1012$ & 37.9113330 & -119.0491670 & 2087.58 & 979333.9 & 979984.32 & 643.92 & -233.596 & -1.517 & 0.24 & 2.66 & 2.9 & 203.58 & -6.5 & -240.1 & -238.71 & -35.13 \\
\hline $10 \mathrm{MB} 1013$ & 37.9140000 & -119.0456670 & 2088.92 & 979332.2 & 979984.56 & 644.33 & -233.746 & -1.517 & 0.41 & 2.6 & 3.01 & 203.57 & -8.01 & -241.76 & -240.26 & -36.69 \\
\hline $10 \mathrm{MB} 1014$ & 37.9171670 & -119.0431670 & 2093.49 & 979329.6 & 979984.83 & 645.74 & -234.258 & -1.517 & 0.51 & 2.54 & 3.05 & 203.55 & -9.45 & -243.71 & -242.17 & -38.62 \\
\hline $10 \mathrm{MB} 1015$ & 37.9201670 & -119.0401670 & 2082.88 & 979329.9 & 979985.1 & 642.47 & -233.071 & -1.517 & 0.75 & 2.51 & 3.26 & 203.58 & -12.77 & -245.84 & -244.1 & -40.52 \\
\hline $10 \mathrm{MB} 1016$ & 37.9223330 & -119.0365000 & 2079.68 & 979328.6 & 979985.29 & 641.48 & -232.713 & -1.517 & 1.07 & 2.47 & 3.54 & 203.59 & -15.18 & -247.89 & -245.87 & -42.28 \\
\hline $10 \mathrm{MB} 1017$ & 37.9246670 & -119.0330000 & 2070.08 & 979328.7 & 979985.49 & 638.52 & -231.638 & -1.517 & 0.85 & 2.43 & 3.28 & 203.62 & -18.28 & -249.92 & -248.16 & -44.54 \\
\hline $10 \mathrm{MB} 1018$ & 37.9245000 & -119.0285000 & 2042.04 & 979334.1 & 979985.48 & 629.88 & -228.5 & -1.517 & 1.25 & 2.49 & 3.74 & 203.69 & -21.51 & -250.01 & -247.79 & -44.1 \\
\hline $10 \mathrm{MB1019}$ & 37.9265000 & -119.0230000 & 2008.45 & 979340.1 & 979985.65 & 619.52 & -224.742 & -1.516 & 0.81 & 2.57 & 3.38 & 203.76 & -26.03 & -250.77 & -248.9 & -45.14 \\
\hline $10 \mathrm{MB} 1020$ & 37.9281670 & -119.0190000 & 1994.37 & 979342.3 & 979985.8 & 615.18 & -223.166 & -1.515 & 0.4 & 2.58 & 2.98 & 203.79 & -28.34 & -251.51 & -250.04 & -46.25 \\
\hline $10 \mathrm{MB} 1021$ & 37.9291670 & -119.0145000 & 1989.28 & 979342.8 & 979985.89 & 613.61 & -222.597 & -1.515 & 0.22 & 2.56 & 2.78 & 203.79 & -29.47 & -252.07 & -250.8 & -47.01 \\
\hline $10 \mathrm{MB} 1022$ & 37.9313330 & -119.0106670 & 1986.56 & 979342.9 & 979986.08 & 612.77 & -222.293 & -1.514 & 0.09 & 2.47 & 2.56 & 203.79 & -30.45 & -252.74 & -251.69 & -47.9 \\
\hline $10 \mathrm{MB1} 023$ & 37.934 & -119.0073330 & 1987.2 & 979342 & 979986.31 & 612.97 & -222.365 & -1.514 & 0.1 & 2.35 & 2.45 & 203.8 & -31.33 & -253.7 & -252.76 & -48.96 \\
\hline $10 \mathrm{MB} 1024$ & 37.9340000 & -119.0036670 & 1977.73 & 979344.5 & 979986.31 & 610.05 & -221.304 & -1.514 & 0.07 & 2.36 & 2.43 & 203.8 & -31.73 & -253.03 & -252.11 & -48.31 \\
\hline $10 \mathrm{MB} 1025$ & 37.9333330 & -118.9991670 & 1975.01 & 979345.7 & 979986.25 & 609.21 & -221 & -1.514 & 0.06 & 2.36 & 2.42 & 203.82 & 31.29 & -252.29 & -251.39 & -47.57 \\
\hline $10 \mathrm{MB} 1026$ & 37.9331670 & -118.9945000 & 1982.18 & 979344.8 & 979986.24 & 611.42 & -221.802 & -1.514 & 0.07 & 2.28 & 2.35 & 203.8 & -30.02 & -251.82 & -250.99 & -47.19 \\
\hline $10 \mathrm{MB} 1027$ & 37.9331670 & -118.9900000 & 1989.58 & 979344.3 & 979986.24 & 613.7 & -222.631 & -1.515 & 0.08 & 2.21 & 2.29 & 203.77 & -28.25 & -250.88 & -250.1 & -46.33 \\
\hline $10 \mathrm{MB1} 028$ & 37.9330000 & -118.9856670 & 1995.5 & 979344.4 & 979986.22 & 615.53 & -223.292 & -1.515 & 0.07 & 2.14 & 2.21 & 203.75 & -26.27 & -249.56 & -248.87 & -45.12 \\
\hline $10 \mathrm{MB1} 029$ & 37.9330000 & -118.9806670 & 2001.5 & 979345 & 979986.22 & 617.38 & -223.964 & -1.515 & 0.08 & 2.1 & 2.18 & 203.71 & -23.83 & -247.79 & -247.13 & -43.42 \\
\hline $10 \mathrm{MB1} 030$ & 37.9335000 & -118.9750000 & 2015.34 & 979343.7 & 979986.27 & 621.64 & -225.513 & -1.516 & 0.14 & 2.02 & 2.16 & 203.69 & -20.96 & -246.47 & -245.82 & -42.13 \\
\hline 10MB1031 & 37.9356670 & -118.9715000 & 2027.56 & 979341.1 & 979986.46 & 625.41 & -226.88 & -1.516 & 0.18 & 1.93 & 2.11 & 203.61 & -19.99 & -246.87 & -246.27 & -42.66 \\
\hline $10 \mathrm{MB} 1032$ & 37.93 & -118.9 & 2035.03 & 979340.7 & 979986.51 & 627.72 & -227.716 & -1.516 & 0.09 & 1.89 & 1.98 & 203.63 & -18.07 & -245.79 & -245.33 & -41.7 \\
\hline $10 \mathrm{MB} 1033$ & 37.9358330 & -118.9618330 & 2035.76 & 979342.5 & 979986.47 & 627.94 & -227.798 & -1.516 & 0.06 & 1.9 & 1.96 & 203.64 & -16.06 & -243.86 & -243.42 & -39.78 \\
\hline $10 \mathrm{MB1} 034$ & 37.9366670 & -118.9571670 & 2039.57 & 979343.2 & 979986.54 & 629.12 & -228.224 & -1.517 & 0.05 & 1.89 & 1.94 & 203.62 & -14.24 & -242.47 & -242.04 & -38.42 \\
\hline $10 \mathrm{MB} 1035$ & 37.9373330 & -118.9536670 & 2037.86 & 979344.4 & 979986.6 & 628.59 & -228.033 & -1.517 & 0.05 & 1.88 & 1.93 & 203.6 & -13.6 & -241.63 & -241.22 & -37.62 \\
\hline MB1036 & 37.93 & & 2038.96 & 979345.5 & 979986.69 & 628.93 & -228.156 & -1.517 & 0.04 & 1.88 & 1.92 & 203.58 & 28 & -24 & 0.03 & -36.45 \\
\hline $10 \mathrm{MB} 1037$ & 37.9390000 & -118.9435000 & 2040.79 & 979345.8 & 979986.75 & 629.49 & -228.361 & -1.517 & 0.05 & 1.88 & 1.93 & 203.56 & -11.41 & -239.77 & -239.36 & -35.8 \\
\hline $10 \mathrm{MB} 1038$ & 37.9338330 & -118.9386670 & 2063.83 & 979343.5 & 979986.29 & 636.6 & -230.939 & -1.517 & 0.1 & 1.92 & 2.02 & 203.52 & -6.16 & -237.1 & -236.6 & -33.08 \\
\hline $10 \mathrm{MB1} 039$ & 37.9271670 & -118.9408330 & 2083.09 & 979339.3 & 979985.71 & 642.54 & -233.095 & -1.517 & 0.13 & 1.97 & 2.1 & 203.53 & -3.88 & -236.98 & -236.39 & -32.86 \\
\hline $10 \mathrm{MB} 1040$ & 37.9215000 & -118.9440000 & 2103.79 & 979334.3 & 979985.21 & 648.92 & -235.41 & -1.517 & 0.13 & 1.98 & 2.11 & 203.54 & -1.98 & -237.39 & -236.8 & -33.26 \\
\hline MB1041 & 37.90 & & 2158.62 & 979323.6 & 979983.81 & 665.82 & -241.5 & -1.514 & 15 & 2.06 & 2.21 & & 5.63 & & & -31.65 \\
\hline $10 \mathrm{MB} 1042$ & 37.8981670 & -118.9570000 & 2197.76 & 979317 & 979983.17 & 677.89 & -245.925 & -1.511 & 0.17 & 2.06 & 2.23 & 203.56 & 11.74 & -234.18 & -233.46 & -29.9 \\
\hline $10 \mathrm{MB} 1043$ & 37.8965000 & -118.9623330 & 2189.62 & 979317.9 & 979983.02 & 675.38 & -245.015 & -1.512 & 0.17 & 2.12 & 2.29 & 203.6 & 10.28 & -234.73 & -233.96 & -30.36 \\
\hline $10 \mathrm{MB1} 044$ & 37.9040000 & -118.9620000 & 2148.14 & 979325 & 979983.68 & 662.59 & -240.373 & -1.515 & 0.17 & 2.1 & 2.27 & 203.61 & 3.89 & -236.48 & -235.72 & -32.11 \\
\hline $10 \mathrm{MB} 1045$ & 37.9110000 & -118.9575000 & 2117.32 & 979330.7 & 979984.29 & 653.09 & -236.925 & -1.516 & 0.15 & 2.08 & 2.23 & 203.61 & -0.52 & -237.44 & 36.73 & -33.12 \\
\hline $10 \mathrm{MB} 1046$ & & -118.9553330 & 2086.97 & 979336.7 & 979984.91 & 643.73 & -233.528 & -1.517 & 0.13 & 2.06 & 2.19 & .61 & -4.49 & -238.02 & 37.35 & -33.74 \\
\hline $10 \mathrm{MB} 1047$ & 37.9253330 & -118.9550000 & 2067.67 & 979339.9 & 979985.55 & 637.78 & -231.369 & -1.517 & 0.07 & 1.99 & 2.06 & 203.61 & -7.82 & -239.19 & -238.65 & -35.04 \\
\hline $10 \mathrm{MB} 1048$ & 37.9315000 & -118.9546670 & 2050.97 & 979343 & 979986.09 & 632.63 & -229.5 & -1.517 & 0.05 & 1.94 & 1.99 & 203.61 & -10.45 & -239.95 & -239.48 & -35.87 \\
\hline $10 \mathrm{MB1} 049$ & 37.9258330 & -118.9808330 & 2028.84 & 979340.4 & 979985.59 & 625.81 & -227.024 & -1.516 & 0.1 & 2.17 & 2.27 & 203.73 & -19.42 & -246.44 & -245.69 & -41.96 \\
\hline $10 \mathrm{MB} 1050$ & 37.9225000 & -118.9888330 & 2029.57 & 979337.8 & 979985.3 & 626.03 & -227.105 & -1.516 & 0.14 & 2.33 & 2.47 & 203.73 & -21.45 & -248.56 & -247.6 & -43.87 \\
\hline $10 \mathrm{MB} 1051$ & & & 2030.36 & & 979985.04 & 626.28 & -227.194 & -1.516 & 0.36 & 2.55 & 2.91 & 203.73 & 2.76 & -249.95 & -248.56 & -44.83 \\
\hline $10 \mathrm{MB} 1052$ & 38.0453330 & -119.1588330 & 2100.44 & 979356.9 & 979996.08 & 647.88 & -235.035 & -1.517 & 0.09 & 5.32 & 5.41 & 202.65 & 8.7 & -226.34 & -222.44 & -19.79 \\
\hline $10 \mathrm{MB} 1053$ & 38.0468330 & -119.1536670 & 2088.15 & 979359.7 & 979996.21 & 644.09 & -233.661 & -1.517 & 0.07 & 4.84 & 4.91 & 202.71 & 7.59 & -226.07 & -222.68 & -19.97 \\
\hline
\end{tabular}




\begin{tabular}{|c|c|c|c|c|c|c|c|c|c|c|c|c|c|c|c|c|}
\hline ID & LAT & LONG & $\mid$ ELEV_M| & OG & TG & FAC & $\mathrm{BC}$ & $\mathrm{CC}$ & ITC & OTC & \begin{tabular}{|l|} 
TTC \\
\end{tabular} & $\mid$ TISOC & FAA & SBA & CBA & ISO \\
\hline $10 \mathrm{MB} 1054$ & 38.0478330 & -119.1495000 & 2078.13 & 979362.6 & 979996.29 & 641 & -232.539 & -1.517 & 0.04 & 4.52 & 4.56 & 202.73 & 7.3 & -225.24 & -222.19 & -19.46 \\
\hline 10MB1055 & 38.0490000 & -119.1450000 & 2068.46 & 979364.6 & 979996.4 & 638.02 & -231.457 & -1.517 & 0.02 & 4.21 & 4.23 & 202.76 & 6.27 & -225.19 & -222.47 & -19.71 \\
\hline 10MB1056 & 38.0500000 & -119.1406670 & 2064.08 & 979365.9 & 979996.48 & 636.67 & -230.966 & -1.517 & 0.02 & 3.95 & 3.97 & 202.79 & 6.07 & -224.9 & -222.44 & -19.65 \\
\hline $10 \mathrm{MB} 1057$ & 38.0511670 & -119.1363330 & 2061.94 & 979366.8 & 979996.59 & 636.01 & -230.728 & -1.517 & 0.02 & 3.7 & 3.72 & 202.79 & 6.2 & -224.53 & -222.33 & -19.54 \\
\hline 10MB1058 & 38.0521670 & -119.1321670 & 2059.11 & 979367.4 & 979996.68 & 635.14 & -230.41 & -1.517 & 0.03 & 3.52 & 3.55 & 202.8 & 5.85 & -224.56 & -222.53 & -19.73 \\
\hline 10MB1059 & 38.0538330 & -119.1266670 & 2049.75 & 979368.8 & 979996.82 & 632.25 & -229.363 & -1.517 & 0.09 & 3.34 & 3.43 & 202.83 & 4.22 & -225.15 & -223.23 & -20.4 \\
\hline $10 \mathrm{MB} 1060$ & 38.0553330 & -119.1218330 & 2052.37 & 979368.4 & 979996.95 & 633.06 & -229.657 & -1.517 & 0.07 & 3.15 & 3.22 & 202.83 & 4.53 & -225.12 & -223.42 & -20.59 \\
\hline 10MB1061 & 38.0566670 & -119.1178330 & 2053.29 & 979369.6 & 979997.07 & 633.34 & -229.759 & -1.517 & 0.09 & 3.01 & 3.1 & 202.83 & 5.91 & -223.85 & -222.27 & -19.44 \\
\hline 10MB1062 & 38.0581670 & -119.1130000 & 2052.04 & 979371.1 & 979997.2 & 632.96 & -229.619 & -1.517 & 0.16 & 2.87 & 3.03 & 202.84 & 6.89 & -222.73 & -221.22 & -18.38 \\
\hline $10 \mathrm{MB} 1063$ & 38.0595000 & -119.1086670 & 2045.67 & 979373 & 979997.32 & 630.99 & -228.906 & -1.517 & 0.25 & 2.79 & 3.04 & 202.82 & 6.7 & -222.21 & -220.68 & -17.86 \\
\hline 10MB1064 & 38.0608330 & -119.1045000 & 2037.07 & 979375.9 & 979997.44 & 628.34 & -227.944 & -1.517 & 0.29 & 2.72 & 3.01 & 202.84 & 6.82 & -221.12 & -219.63 & -16.79 \\
\hline 10MB1065 & 38.0621670 & -119.1006670 & 2032.92 & 979376.7 & 979997.55 & 627.07 & -227.481 & -1.516 & 0.31 & 2.65 & 2.96 & 202.84 & 6.23 & -221.25 & -219.81 & -16.97 \\
\hline 10MB1066 & 38.0636670 & -119.0961670 & 2030.91 & 979376 & 979997.68 & 626.44 & -227.256 & -1.516 & 0.25 & 2.58 & 2.83 & 202.82 & 4.8 & -222.46 & -221.15 & -18.33 \\
\hline 10MB1067 & 38.0648330 & -119.0925000 & 2028.84 & 979375.1 & 979997.79 & 625.81 & -227.024 & -1.516 & 0.22 & 2.52 & 2.74 & 202.81 & 3.16 & -223.86 & -222.64 & -19.83 \\
\hline 10MB1068 & 38.0661670 & -119.0885000 & 2023.45 & 979375.3 & 979997.9 & 624.14 & -226.42 & -1.516 & 0.24 & 2.48 & 2.72 & 202.83 & 1.53 & -224.89 & -223.68 & -20.85 \\
\hline 10MB1069 & 38.0676670 & -119.0836670 & 2005.49 & 979379.1 & 979998.04 & 618.61 & -224.411 & -1.515 & 0.15 & 2.49 & 2.64 & 202.85 & -0.32 & -224.73 & -223.61 & -20.76 \\
\hline 10MB1070 & 38.0693330 & -119.0786670 & 1997.2 & 979380.2 & 979998.18 & 616.05 & -223.483 & -1.515 & 0.12 & 2.44 & 2.56 & 202.82 & -1.91 & -225.39 & -224.34 & -21.52 \\
\hline 10MB1071 & 38.0693330 & -119.0786670 & 1997.2 & 979381.6 & 979998.18 & 616.05 & -223.483 & -1.515 & 0.11 & 2.44 & 2.55 & 202.82 & -0.56 & -224.04 & -223 & -20.18 \\
\hline 10MB1072 & 38.0718330 & -119.0706670 & 1978.27 & 979383 & 979998.4 & 610.22 & -221.365 & -1.514 & 0.1 & 2.38 & 2.48 & 202.83 & -5.16 & -226.53 & -225.56 & -22.73 \\
\hline $10 \mathrm{MB} 1073$ & 38.0733330 & -119.0663330 & 1973.76 & 979384.4 & 979998.53 & 608.82 & -220.861 & -1.514 & 0.08 & 2.34 & 2.42 & 202.8 & -5.34 & -226.2 & -225.3 & -22.5 \\
\hline 10MB1074 & 38.0745000 & -119.0626670 & 1970.68 & 979383.9 & 979998.64 & 607.88 & -220.516 & -1.513 & 0.07 & 2.28 & 2.35 & 202.8 & -6.82 & -227.34 & -226.5 & -23.7 \\
\hline $10 \mathrm{MB} 1075$ & 38.0758330 & -119.0585000 & 1970.68 & 979382.9 & 979998.75 & 607.88 & -220.516 & -1.513 & 0.06 & 2.22 & 2.28 & 202.77 & -7.96 & -228.48 & -227.71 & -24.94 \\
\hline 10MB1076 & 38.0773330 & -119.0540000 & 1971.87 & 979383.6 & 979998.88 & 608.24 & -220.649 & -1.513 & 0.06 & 2.15 & 2.21 & 202.75 & -7.09 & -227.74 & -227.04 & -24.29 \\
\hline 10MB1077 & 38.0788330 & -119.0493330 & 1974.98 & 979380.5 & 979999.02 & 609.2 & -220.997 & -1.514 & 0.06 & 2.07 & 2.13 & 202.69 & -9.3 & -230.3 & -229.68 & -26.99 \\
\hline 10MB1078 & 38.0801670 & -119.0453330 & 1976.29 & 979380.5 & 979999.13 & 609.6 & -221.144 & -1.514 & 0.07 & 2.02 & 2.09 & 202.68 & -9.07 & -230.22 & -229.64 & -26.96 \\
\hline 10MB1079 & 38.0811670 & -119.0420000 & 1975.53 & 979380.8 & 979999.22 & 609.37 & -221.058 & -1.514 & 0.06 & 1.98 & 2.04 & 202.65 & -9.09 & -230.14 & -229.62 & -26.97 \\
\hline $10 \mathrm{MB} 1080$ & 38.0826670 & -119.0375000 & 1971.9 & 979381.5 & 979999.35 & 608.25 & -220.653 & -1.513 & 0.06 & 1.95 & 2.01 & 202.61 & -9.58 & -230.23 & -229.73 & -27.12 \\
\hline 10MB1081 & 38.0840000 & -119.0336670 & 1965.23 & 979382.8 & 979999.47 & 606.19 & -219.906 & -1.513 & 0.06 & 1.95 & 2.01 & 202.57 & -10.5 & -230.41 & -229.91 & -27.34 \\
\hline 10MB1082 & 38.0855000 & -119.0290000 & 1965.08 & 979383 & 979999.6 & 606.15 & -219.889 & -1.513 & 0.05 & 1.91 & 1.96 & 202.53 & -10.46 & -230.35 & -229.9 & -27.37 \\
\hline $10 \mathrm{MB} 1083$ & 38.0866670 & -119.0253330 & 1965.11 & 979382.9 & 979999.7 & 606.16 & -219.892 & -1.513 & 0.04 & 1.88 & 1.92 & 202.49 & -10.67 & -230.56 & -230.16 & -27.67 \\
\hline 10MB1084 & 38.0881670 & -119.0206670 & 1965.59 & 979382.2 & 979999.84 & 606.31 & -219.947 & -1.513 & 0.04 & 1.83 & 1.87 & 202.47 & -11.3 & -231.25 & -230.89 & -28.42 \\
\hline 10MB1085 & 38.0895000 & -119.0168330 & 1966.72 & 979381.8 & 979999.95 & 606.65 & -220.073 & -1.513 & 0.03 & 1.8 & 1.83 & 202.43 & -11.47 & -231.55 & -231.23 & -28.8 \\
\hline 10MB1086 & 38.0910000 & -119.0120000 & 1969.22 & 979380.8 & 980000.08 & 607.42 & -220.352 & -1.513 & 0.03 & 1.74 & 1.77 & 202.41 & -11.83 & -232.19 & -231.93 & -29.52 \\
\hline 10MB1087 & 38.0921670 & -119.0083330 & 1970.01 & 979380.1 & 980000.19 & 607.67 & -220.441 & -1.513 & 0.02 & 1.72 & 1.74 & 202.37 & -12.41 & -232.85 & -232.63 & -30.26 \\
\hline 10MB1088 & 38.0936670 & -119.0035000 & 1971.08 & 979379.2 & 980000.32 & 608 & -220.56 & -1.513 & 0.03 & 1.68 & 1.71 & 202.32 & -13.14 & -233.7 & -233.5 & -31.18 \\
\hline 10MB1089 & 38.0955000 & -118.9981670 & 1972.6 & 979377.8 & 980000.48 & 608.47 & -220.731 & -1.513 & 0.01 & 1.63 & 1.64 & 202.27 & -14.17 & -234.9 & -234.77 & -32.5 \\
\hline 10MB1090 & 38.0968330 & -118.9936670 & 1973.52 & 979377 & 980000.6 & 608.75 & -220.833 & -1.513 & 0.02 & 1.6 & 1.62 & 202.22 & -14.87 & -235.71 & -235.6 & -33.38 \\
\hline 10MB1091 & 38.0990000 & -118.9873330 & 1974.04 & 979376.6 & 980000.79 & 608.91 & -220.891 & -1.514 & 0.01 & 1.57 & 1.58 & 202.1 & -15.3 & -236.19 & -236.13 & -34.03 \\
\hline 10MB1092 & 38.1003330 & -118.9831670 & 1974.92 & 979376.1 & 980000.9 & 609.18 & -220.99 & -1.514 & 0.03 & 1.55 & 1.58 & 202.06 & -15.62 & -236.61 & -236.54 & -34.48 \\
\hline 10MB1093 & 38.1018330 & -118.9786670 & 1976.41 & 979375.3 & 980001.04 & 609.64 & -221.157 & -1.514 & 0.02 & 1.53 & 1.55 & 202.02 & -16.13 & -237.29 & -237.25 & -35.23 \\
\hline 10MB1094 & 38.1031670 & -118.9743330 & 1976.05 & 979374.7 & 980001.15 & 609.53 & -221.116 & -1.514 & 0.02 & 1.52 & 1.54 & 201.97 & -16.97 & -238.08 & -238.06 & -36.09 \\
\hline 10MB1095 & 38.1046670 & -118.9696670 & 1977.21 & 979373.8 & 980001.28 & 609.89 & -221.246 & -1.514 & 0.03 & 1.48 & 1.51 & 201.92 & -17.61 & -238.86 & -238.86 & -36.94 \\
\hline 10MB1096 & 38.1061670 & -118.9653330 & 1980.38 & 979372.4 & 980001.42 & 610.86 & -221.601 & -1.514 & 0.03 & 1.45 & 1.48 & 201.86 & -18.12 & -239.72 & -239.75 & -37.89 \\
\hline 10MB1097 & 38.1113330 & -118.9493330 & 1987.88 & 979370.2 & 980001.87 & 613.18 & -222.44 & -1.514 & 0.04 & 1.38 & 1.42 & 201.63 & -18.46 & -240.9 & -240.99 & -39.36 \\
\hline 10MB1098 & 38.1168330 & -118.9323330 & 2001.74 & 979369.2 & 980002.35 & 617.45 & -223.992 & -1.515 & 0.03 & 1.29 & 1.32 & 201.39 & -15.67 & -239.66 & -239.85 & -38.46 \\
\hline
\end{tabular}




\begin{tabular}{|c|c|c|c|c|c|c|c|c|c|c|c|c|c|c|c|c|}
\hline ID & LAT & LONG & ELEV_M| & OG & TG & FAC & $\mathrm{BC}$ & $\mathrm{CC}$ & ITC & OTC & TTC & TISOC & FAA & SBA & CBA & ISO \\
\hline 10MB1099 & 38.1221670 & -118.9158330 & 2024.91 & 979366.1 & 980002.82 & 624.59 & -226.584 & -1.516 & 0.03 & 1.2 & 1.23 & 201.08 & -12.16 & -238.75 & -239.03 & -37.95 \\
\hline $10 \mathrm{MB} 1100$ & 38.1280000 & -118.8980000 & 2042.5 & 979364.7 & 980003.33 & 630.02 & -228.552 & -1.517 & 0.02 & 1.14 & 1.16 & 200.77 & -8.61 & -237.16 & -237.52 & -36.75 \\
\hline 10MB1101 & 38.1330000 & -118.8825000 & 2061.82 & 979366.5 & 980003.77 & 635.97 & -230.714 & -1.517 & 0.03 & 1.1 & 1.13 & 200.46 & -1.26 & -231.98 & & -31.91 \\
\hline $10 \mathrm{MB} 1102$ & 38.1386670 & -118.8646670 & 2076.48 & 979366.1 & 980004.27 & 640.49 & -232.354 & -1.517 & 0.06 & 1.1 & 1.16 & 200.17 & 2.3 & -230.06 & -230.41 & -30.24 \\
\hline 100101 & 37.8870000 & -119.0891670 & 2099.1 & 979337.5 & 979982.19 & 647.47 & -234.885 & -1.517 & 0.02 & 3.77 & 3.79 & 203.26 & 2.79 & -232.1 & -229.83 & -26.57 \\
\hline 100102 & 37.8891670 & -119.0851670 & 2092.6 & 979338.4 & 979982.38 & 645.47 & -234.159 & -1.517 & 0.02 & 3.62 & 3.64 & 203.31 & 1.48 & -232.68 & -230.55 & -27.24 \\
\hline 100103 & 37.8910000 & -119.0816670 & 2089.46 & 979339 & 979982.54 & 644.5 & -233.807 & -1.517 & 0.01 & 3.48 & 3.49 & 203.33 & 0.97 & -232.84 & -230.87 & -27.54 \\
\hline 100104 & 37.8931670 & -119.0776670 & 2085.05 & 979339.6 & 979982.73 & 643.14 & -233.313 & -1.517 & 0.01 & 3.36 & 3.37 & 203.36 & -0.04 & -233.35 & -231.5 & -28.14 \\
\hline 100105 & 37.8951670 & -119.0741670 & 2084.62 & 979339.5 & 979982.91 & 643.01 & -233.265 & -1.517 & 0.01 & 3.22 & 3.23 & 203.39 & -0.43 & -233.7 & -231.99 & -28.6 \\
\hline 100106 & 37.8953330 & -119.0740000 & 2083.03 & 979339.5 & 979982.92 & 642.52 & -233.088 & -1.517 & 0.01 & 3.23 & 3.24 & 203.4 & -0.95 & -234.04 & -232.31 & -28.91 \\
\hline 100107 & 37.8978330 & -119.0705000 & 2081.14 & 979339.4 & 979983.14 & 641.93 & -232.876 & -1.517 & 0.01 & 3.13 & 3.14 & 203.45 & -1.78 & -234.66 & -233.03 & -29.58 \\
\hline 100108 & 37.9000000 & -119.0665000 & 2081.33 & 979339.3 & 979983.33 & 641.99 & -232.897 & -1.517 & 0.01 & 299 & 3 & 203.51 & -2.02 & -234.92 & 33.44 & -29.93 \\
\hline 100109 & 0000 & -119.0618330 & 2079.96 & 979338.8 & 979983.59 & 641.57 & -232.743 & -1.517 & 0.01 & 2.91 & 2.92 & & -3.27 & & & -31.08 \\
\hline 100110 & 37.9048330 & -119.0590000 & 2080.29 & 979337.9 & 979983.75 & 641.67 & -232.781 & -1.517 & 0.02 & 2.86 & 2.88 & 203.55 & -4.16 & -236.94 & -235.57 & -32.02 \\
\hline 100111 & 37.9071670 & -119.0555000 & 2081.84 & 979336.9 & 979983.96 & 642.15 & -232.955 & -1.517 & 0.06 & 2.8 & 2.86 & 203.56 & -4.91 & -237.87 & -236.52 & -32.96 \\
\hline 100112 & 37.9093330 & -119 & 2084.86 & 979335.6 & 979984.15 & 643.08 & -233.292 & -1.517 & 0.14 & 2.73 & 2.87 & 3.57 & -5.48 & 3.77 & -237.42 & -33.85 \\
\hline 100113 & 37.9118330 & -119.0485000 & 2089.1 & 979333.6 & 979984.37 & 644.39 & -233.766 & -1.517 & 0.25 & 2.65 & 2.9 & 203.58 & -6.39 & -240.16 & -238.78 & -35.2 \\
\hline 100114 & 37.9140000 & -119.0455000 & 2089.83 & 979332.1 & 979984.56 & 644.61 & -233.848 & -1.517 & 0.43 & 2.59 & 3.02 & .56 & -7.8 & -241.65 & 40.14 & -36.58 \\
\hline 100115 & 37.9171670 & -119.0430000 & 2094.31 & 979329.7 & 979984.83 & 645.99 & -234.35 & -1.517 & 0.54 & 2.54 & 3.08 & 203.55 & -9.18 & -243.53 & -241.97 & -38.42 \\
\hline 100116 & 37.9201670 & 1670 & 2084.25 & 979329.8 & 979985.1 & 642.89 & -233.224 & -1.517 & 0.73 & 2.51 & 3.24 & .58 & -12.41 & & -243.91 & -40.33 \\
\hline 10MB0191 & 38.0390000 & -119.1676670 & 2139.06 & 979347.1 & 979995.52 & 659.79 & -239.357 & -1.515 & 0.66 & 6.26 & 6.92 & 202.51 & 11.35 & -228.01 & -222.6 & -20.09 \\
\hline 10MB0192 & 38.0338330 & -119.1713330 & 2174.05 & 979337.9 & 979995.07 & 670.57 & -243.272 & -1.513 & 1.17 & 6.77 & 7.94 & 2.46 & 13.45 & -229.82 & -223.39 & -20.93 \\
\hline $10 \mathrm{MB} 0193$ & 38.0308330 & -119.1790000 & 2223.73 & 979327.2 & 979994.8 & 685.89 & -248.831 & -1.509 & 2.76 & 7.47 & 10.23 & 202.27 & 18.27 & -230.56 & 221.84 & -19.57 \\
\hline 10MB0194 & .0323330 & 005000 & 65.58 & 979314.8 & 979994.93 & 698.79 & -253.514 & -1.504 & 5.45 & 8.12 & 13.57 & 2.07 & 18.61 & & & -20.77 \\
\hline 10MB0195 & 38.0345000 & -119.2056670 & 2323.55 & 979301.2 & 979995.12 & 716.66 & -260.001 & -1.495 & 6.78 & 8.85 & 15.63 & 201.78 & 22.69 & -237.31 & -223.17 & -21.39 \\
\hline 10MB0196 & 38.0338330 & -119.2140000 & 2364.43 & 979293.6 & 979995.07 & 729.26 & -264.575 & -1.487 & 6.71 & 9.28 & 15.99 & 201.6 & 27.82 & -236.75 & -222.25 & -20.65 \\
\hline 10MB0197 & 38.0283330 & -119.2388330 & 2380.46 & 979287.5 & 979994.58 & 734.21 & -266.369 & -1.484 & 10.17 & 11.99 & 22.16 & 201.15 & 27.11 & -239.26 & -218.59 & -17.44 \\
\hline 10MB0198 & 38.0271670 & -119.2471670 & 2435.29 & 979276.7 & 979994.48 & 751.11 & -272.505 & -1.471 & 10.54 & 11.71 & 22.25 & 200.87 & 33.28 & -239.22 & -218.44 & -17.57 \\
\hline B0199 & 1670 & 330 & 62.36 & 979271.9 & 979994.22 & 759.45 & -27 & -1.463 & 9.95 & 11.89 & 21.84 & 0.69 & 37. & & & -17.35 \\
\hline 10MB0200 & 38.0316670 & -119.2280000 & 2392.04 & 979284.8 & 979994.88 & 737.78 & -267.665 & -1.481 & 10.38 & 10.28 & 20.66 & 201.31 & 27.74 & -239.92 & -220.74 & -19.43 \\
\hline $10 \mathrm{MB} 0201$ & 37.9500000 & -119.2098330 & 2631.95 & 979234.2 & 979987.71 & 811.73 & -294.51 & -1.407 & 14.33 & 8.9 & 23.23 & 200.74 & 58.18 & -236.33 & -214.51 & -13.77 \\
\hline $10 \mathrm{MB} 0202$ & 37.9476670 & -119.1901670 & 2494.45 & 979266.5 & 979987.51 & 769.35 & -279.125 & -1.454 & 9.54 & 9.43 & 18.97 & 201.38 & 48.32 & -230.8 & 213.29 & -11.91 \\
\hline & & & & 979281 & 979986.97 & 741.16 & -268.893 & -1.478 & 11.35 & 9.68 & 21.03 & & 35.19 & & & -12.5 \\
\hline 10MB0204 & 5000 & 0000 & 2233.33 & 979321.1 & 979986.27 & 688.85 & -249.906 & -1.508 & 4.2 & 7.62 & 11.82 & 202.44 & 23.73 & -226 & -215.86 & -13.42 \\
\hline $10 \mathrm{MB} 0205$ & 37.9393330 & -119.1350000 & 2196.48 & 979328.8 & 979986.78 & 677.49 & -245.782 & -1.512 & 2.51 & 6.15 & 8.66 & 202.73 & 19.53 & -226.25 & -219.1 & -16.37 \\
\hline $10 \mathrm{MB} 0206$ & 37.9443330 & -119.1170000 & 2141.83 & 979341 & 979987.22 & 660.64 & -239.667 & -1.515 & 1.52 & 4.74 & 6.26 & 203.01 & 14.46 & -225.2 & -220.46 & -17.45 \\
\hline $10 \mathrm{MB} 0207$ & 37.8875000 & -119.0995000 & 2109.73 & 979336.1 & 979982.23 & 650.75 & -236.076 & -1.516 & 0.03 & 4.2 & 4.23 & 203.14 & 4.58 & -231.49 & -228.78 & -25.64 \\
\hline 10MB0208 & & & 2131.59 & 979330.9 & 979981.75 & 657.49 & & -1.516 & 0.07 & 4.53 & 4.6 & 202.99 & 6.59 & & & -25.86 \\
\hline 10MB0209 & .8753330 & & 2151.49 & 979325 & 979981.17 & 663.62 & -240.748 & -1.5 & 0.17 & 4.71 & 4.88 & 202.85 & 7.5 & -233.25 & -229.88 & -27.03 \\
\hline $10 \mathrm{MB} 0210$ & 37.8613330 & -119.1083330 & 2192.94 & 979314.9 & 979979.94 & 676.4 & -245.387 & -1.512 & 0.38 & 4.81 & 5.19 & 202.68 & 11.36 & -234.03 & -230.35 & -27.67 \\
\hline $10 \mathrm{MB} 0211$ & 37.8425000 & -119.1180000 & 2186.54 & 979312.7 & 979978.29 & 674.43 & -244.67 & -1.512 & 2.58 & 6.99 & 9.57 & 202.36 & 8.87 & -235.8 & -227.74 & -25.38 \\
\hline $10 \mathrm{MB} 0212$ & 37.8531670 & -119.1121670 & 2185.02 & 979315.1 & 979979.22 & 673.96 & -244.5 & -1.513 & 1.58 & 5.56 & 7.14 & 202.56 & 9.88 & -234.62 & -228.99 & -26.43 \\
\hline $10 \mathrm{MB} 0213$ & 37.8258330 & 19.1208330 & 2191.79 & 979306.4 & 979976.83 & 676.05 & -245.257 & -1.512 & 4.92 & 8.86 & 13.78 & 202.1 & 5.65 & & -227.34 & -25.24 \\
\hline $10 \mathrm{MB} 0214$ & & -119.1175000 & 2187.52 & 979305 & 979976.16 & & -244.779 & -1.512 & 7.28 & 9.16 & 16.44 & 202.07 & 3.55 & -241.23 & -226.3 & -24.23 \\
\hline $10 \mathrm{MB} 0215$ & 37.8118330 & -119.1091670 & 2175.11 & 979306.5 & 979975.6 & 670.91 & -243.391 & -1.513 & 8.4 & 8.17 & 16.57 & 202.19 & 1.83 & -241.56 & -226.51 & -24.32 \\
\hline
\end{tabular}




\begin{tabular}{|c|c|c|c|c|c|c|c|c|c|c|c|c|c|c|c|c|}
\hline ID & LAT & LONG & |ELEV_M| & OG & TG & FAC & $\mathrm{BC}$ & $\mathrm{CC}$ & ITC & OTC I & TTC | & TISOC & FAA & SBA & CBA & ISO \\
\hline $10 \mathrm{MB} 0216$ & 37.8075000 & -119.1088330 & 2187.82 & 979303.3 & 979975.22 & 674.82 & -244.814 & -1.512 & 9.67 & 8.05 & 17.72 & 202.11 & 2.9 & -241.92 & -225.71 & -23.6 \\
\hline $10 \mathrm{MB} 0217$ & 8003330 & -119.1180000 & 2199.47 & 979301.5 & 979974.6 & 678.41 & -246.116 & -1.511 & 6.8 & 10.15 & 16.95 & 201.78 & 5.36 & -240.75 & -225.32 & -23.54 \\
\hline 10MB0218 & 37.7928330 & 19.1225000 & 2207.76 & 979296.7 & 979973.94 & 680.97 & -247.044 & -1.511 & 4.8 & 11.56 & 16.36 & 01.54 & 3.75 & -243.3 & -228.45 & -26.91 \\
\hline 10MB0219 & 37.7855000 & -119.1260000 & 2202.36 & 979293.8 & 979973.3 & 679.31 & -246.44 & -1.511 & 5.29 & 12.55 & 17.84 & 201.32 & -0.18 & -246.62 & 230.29 & -28.97 \\
\hline $10 \mathrm{MB} 0220$ & .7745000 & 9.1261670 & 2207.51 & 979289 & 979972.34 & 680.9 & -247.017 & & 64 & 12.46 & 20.1 & 201.11 & -2.43 & -249.45 & -230.86 & -29.75 \\
\hline $10 \mathrm{MB} 0221$ & .7690000 & 19.1233330 & 2199.44 & 979290.1 & 979971.85 & 678.41 & -246.113 & & 37 & 12.49 & 19.86 & 201.1 & -3.39 & & & -30.06 \\
\hline $10 \mathrm{MB} 0222$ & 5000 & 19.1116670 & 2234.95 & 979288.2 & 979971.28 & 689.35 & -250.086 & -1.508 & 4.17 & 10.88 & 15.05 & 1.19 & 6.31 & & 0.23 & -29.04 \\
\hline $10 \mathrm{MB} 0223$ & 37.7701670 & 91670 & 2300.48 & 979283.5 & 979971.96 & 709.55 & -257.419 & -1.499 & 2.11 & 6.94 & 9.05 & 201.71 & 21.14 & -236.28 & 28.72 & -27.01 \\
\hline $10 \mathrm{MB} 0224$ & 37.7741670 & -119.0785000 & 2353.45 & 979274.5 & 979972.31 & 725.88 & -263.347 & -1.489 & 3.51 & 5.55 & 9.06 & 01.87 & 28.04 & -235.3 & 27.73 & -25.86 \\
\hline $10 \mathrm{MBC}$ & 37.7 & & 2340.13 & 979273.8 & 979973.47 & 721.78 & -261.857 & -1.492 & 6.3 & 4.36 & 10.66 & 202.29 & 22.15 & -239.71 & 0.54 & -28.25 \\
\hline $10 \mathrm{MB} 0226$ & 1670 & & 2361.86 & 979274 & 979974.32 & 728.48 & -264.288 & -1.487 & 02 & 3.72 & 5.74 & 2.44 & 8.15 & -236.14 & 1.88 & -29.44 \\
\hline $10 \mathrm{MF}$ & 3330 & 8330 & 2333.76 & 979280.9 & 979975.03 & 719.81 & -261.144 & -1.493 & & 3.48 & 4.24 & 02.65 & 5.72 & -235.42 & 2.67 & -30.02 \\
\hline $10 \mathrm{MB} 0228$ & & & 2289.29 & 979276.6 & 979969.42 & 706.11 & -256.168 & -1.5 & & 3.03 & 3.15 & & 13.31 & & 41.2 & -38.16 \\
\hline $10 \mathrm{MB} 0229$ & 37.7275000 & & 2336.35 & 979256.1 & 979968.22 & 720.61 & -261.434 & -1.492 & 08 & 2.98 & 3.06 & & 8.46 & & & -48.7 \\
\hline $10 \mathrm{M}$ & & & 2.84 & 9792 & 9799 & 731.86 & -265.516 & -1.4 & & 3.74 & 4.56 & 202.29 & 2.21 & & & -37.94 \\
\hline $10 \mathrm{M}$ & & & 88.78 & 979252.3 & 9799 & 736.78 & -267.3 & -1.4 & & 3.79 & 4.96 & 202.1 & 21.53 & & 2.29 & -40.19 \\
\hline $10 \mathrm{MB} 0232$ & 1670 & 51670 & 2473.82 & 979239.3 & 979967.05 & 762.99 & -276.816 & -1.46 & & 4.05 & 7.43 & 201.46 & 35.26 & -241.56 & -235.59 & -34.13 \\
\hline $10 \mathrm{MB} 0233$ & 3330 & 9.0550000 & 2536.12 & 979225.7 & 979966.89 & 782.19 & -283.787 & -1.441 & & 4.79 & 8.07 & 200.9 & 40.98 & -242.8 & 36.17 & -35.27 \\
\hline $10 \mathrm{MB} 0234$ & 5000 & -119.0170000 & 2018.63 & 979339 & 979985.39 & 622.66 & -225.881 & -1.516 & 86 & 2.59 & 3.45 & 203.76 & -23.77 & -249.65 & 7.72 & -43.96 \\
\hline & & & & 979 & 979 & 633 & & & & 2.55 & 3.27 & & -19 . & & & -43.95 \\
\hline & & & & & 979 & & & & & & 2.99 & & -4 . & & & -37.27 \\
\hline 10MB0237 & 330 & 5000 & 481.01 & 979268.9 & 979980.95 & 765.2 & -277.621 & -1.4 & & 2.31 & 2.58 & 2.91 & 53.15 & -224.47 & -223.35 & -20.44 \\
\hline $10 \mathrm{MB} 0238$ & 1670 & 18.8713330 & 2547.18 & 979254.9 & 979980.19 & 785.6 & -285.025 & -1.438 & & 2.62 & 2.85 & 02.84 & 60.33 & -224.7 & -223.29 & -20.45 \\
\hline $10 \mathrm{MB} 0239$ & 83330 & 18.8671670 & 2614.12 & 979234.3 & 979978.8 & 806.23 & -292.515 & -1.414 & & 2.96 & 3.17 & 02.81 & 61.69 & -230.83 & -229.07 & -26.26 \\
\hline $10 \mathrm{MB} 0240$ & & & & 979257.3 & 979979.55 & 773.86 & -280.762 & -1.45 & & 2.46 & 2.71 & 203.02 & 51.58 & & 27.93 & -24.91 \\
\hline & & & & & 9799 & 778. & & & & & 3.17 & 203.1 & & & & -30.05 \\
\hline & & & & & 97997 & 779 & & & & & 2.75 & & 95 & & & -29.28 \\
\hline $10 \mathrm{MB} 024$ & & & 4.72 & 979250.6 & 97997 & & -281.3 & & & & 2.86 & & 48. & 04 & .62 & -28.46 \\
\hline $10 \mathrm{MB} 0244$ & 37.7818330 & 8.9383330 & 2419.75 & 979263.2 & 979972.98 & 746.32 & -270.765 & -1.474 & 1.42 & 2.35 & 3.77 & 203.37 & 36.54 & -234.23 & -231.93 & -28.56 \\
\hline $10 \mathrm{MB} 0245$ & 37.7761670 & 18.9466670 & 2303.98 & 979282.3 & 979972.48 & 710.64 & -257.812 & -1.498 & 1.8 & 2.45 & 4.25 & 203.54 & 20.44 & -237.37 & -234.62 & -31.08 \\
\hline & 37.7660000 & & 2308.62 & 979280.9 & 979971.59 & 712.06 & & & & 2.3 & 2.92 & 203.5 & 21.36 & & -235.55 & -32.05 \\
\hline $10 \mathrm{MB} 0247$ & 37.7593330 & -118.9413330 & 2245.67 & 979292.6 & 979971.01 & 692.66 & -251.287 & -1.506 & 0.46 & 2.56 & 3.02 & 203.63 & 14.23 & -237.06 & -235.55 & -31.92 \\
\hline
\end{tabular}




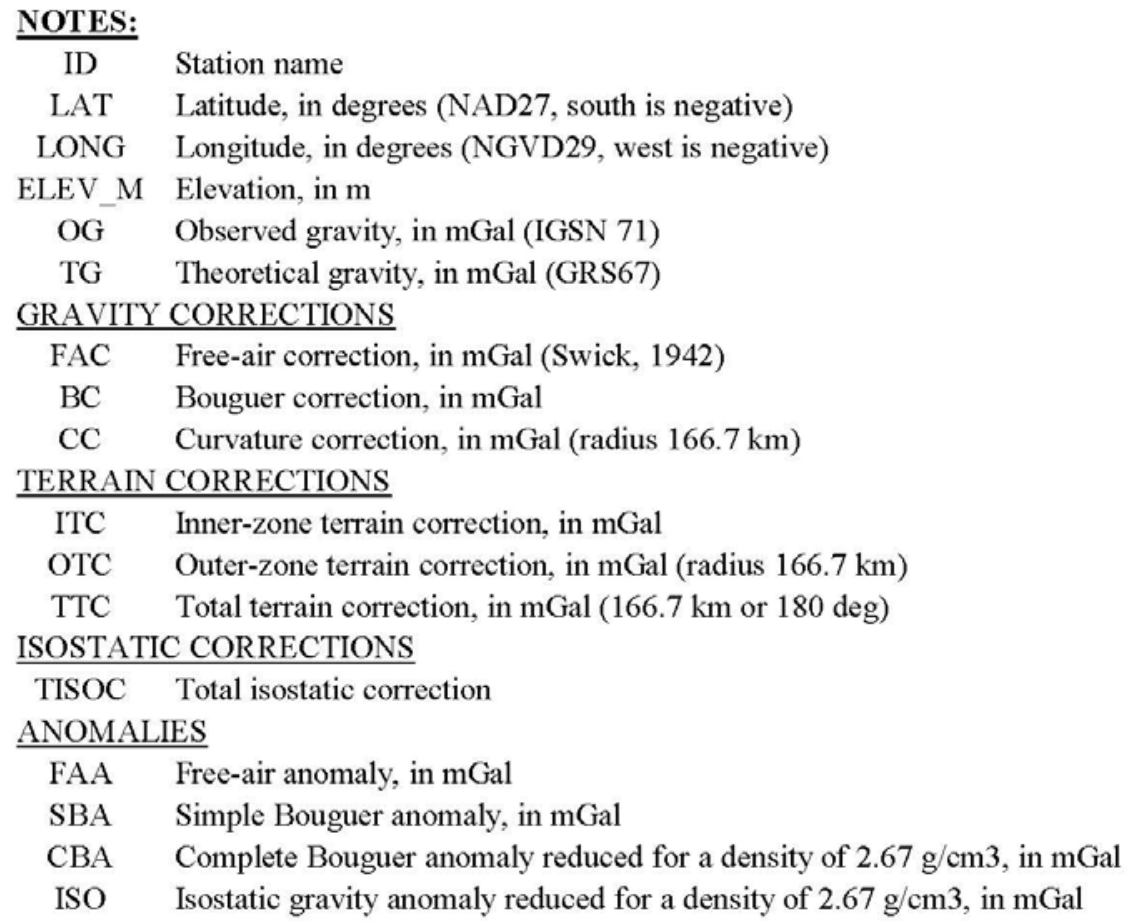


APPENDIX D

TRUCK-TOWED MAGNETOMETER PROFILES 

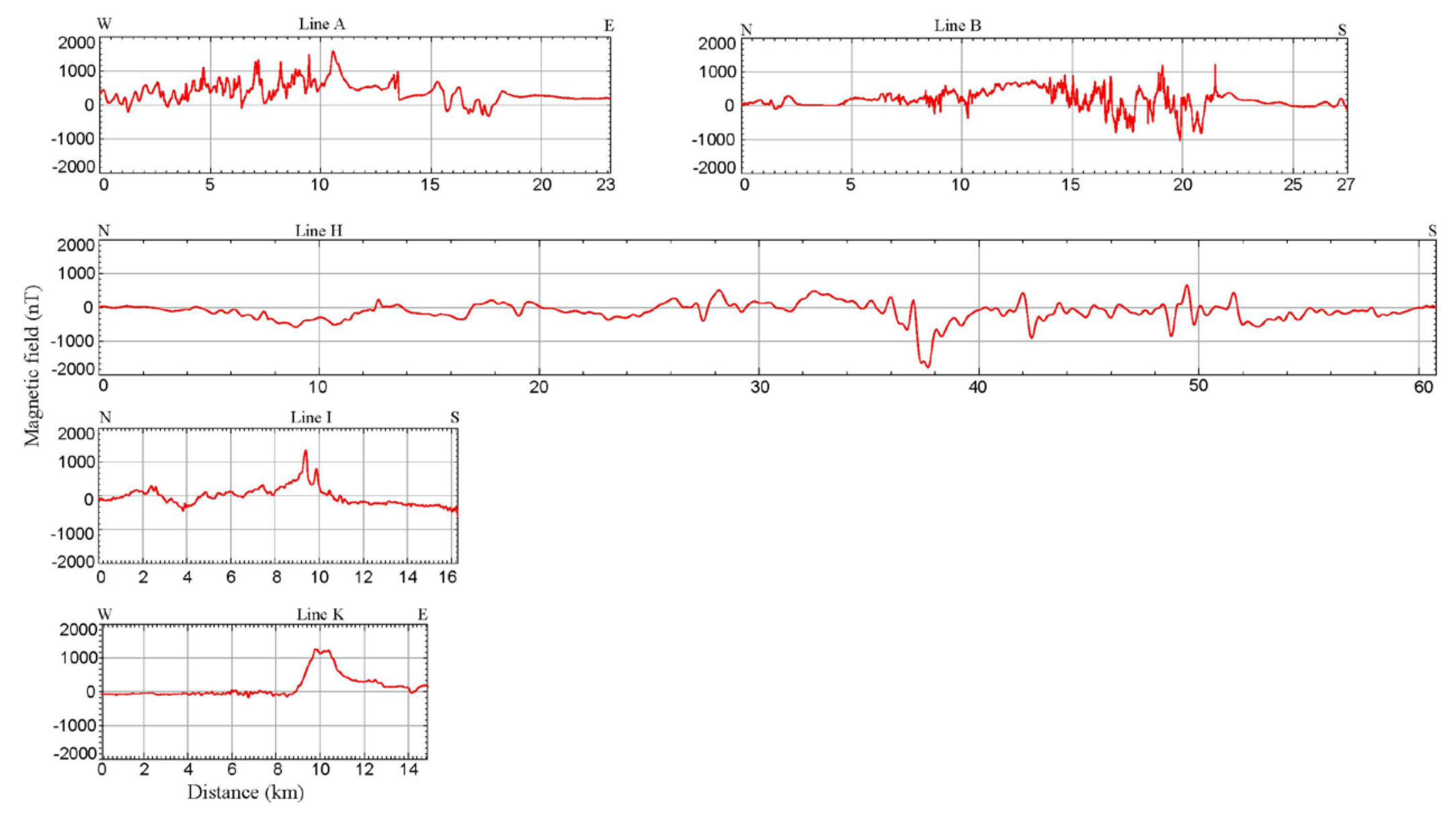

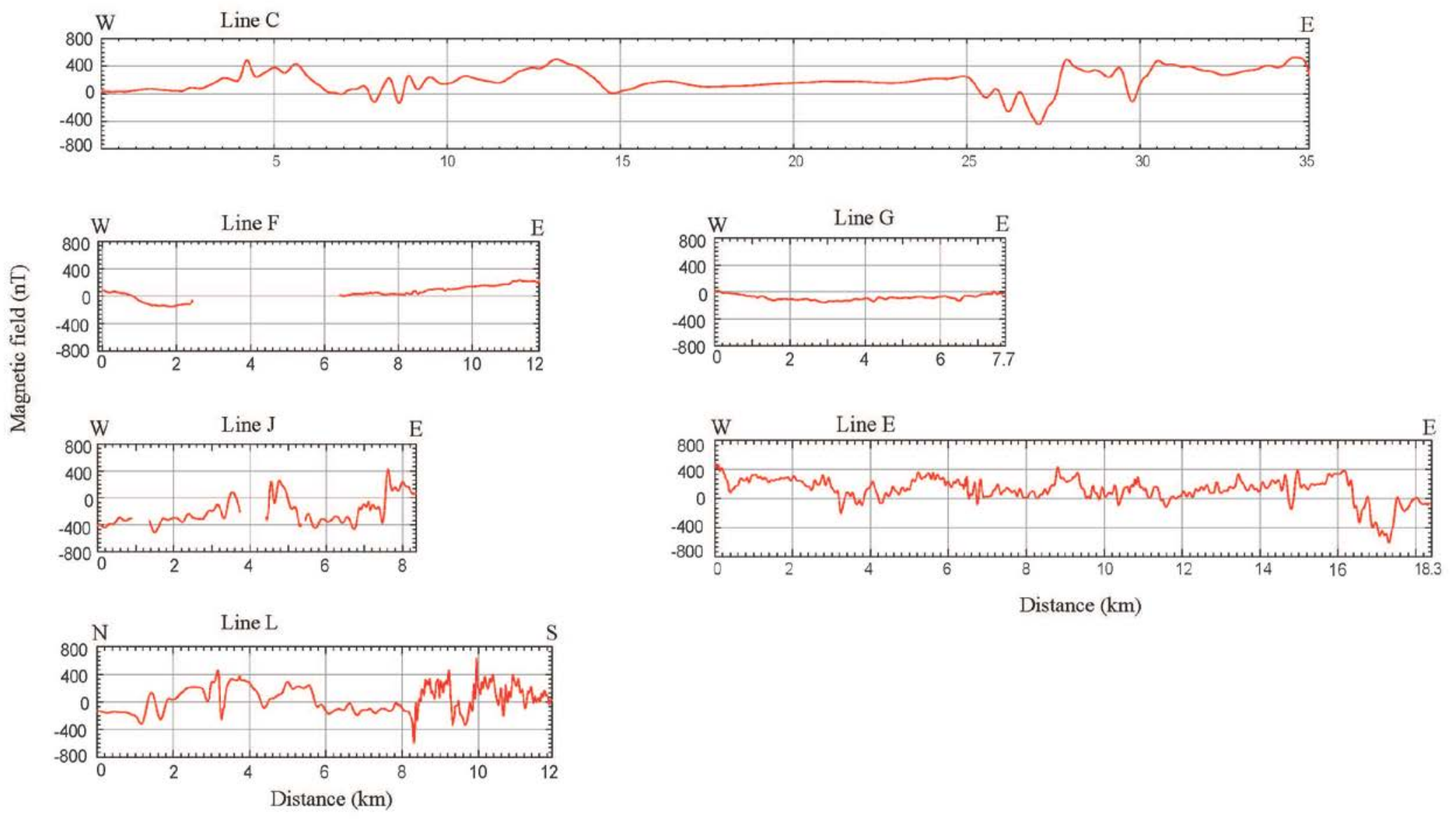

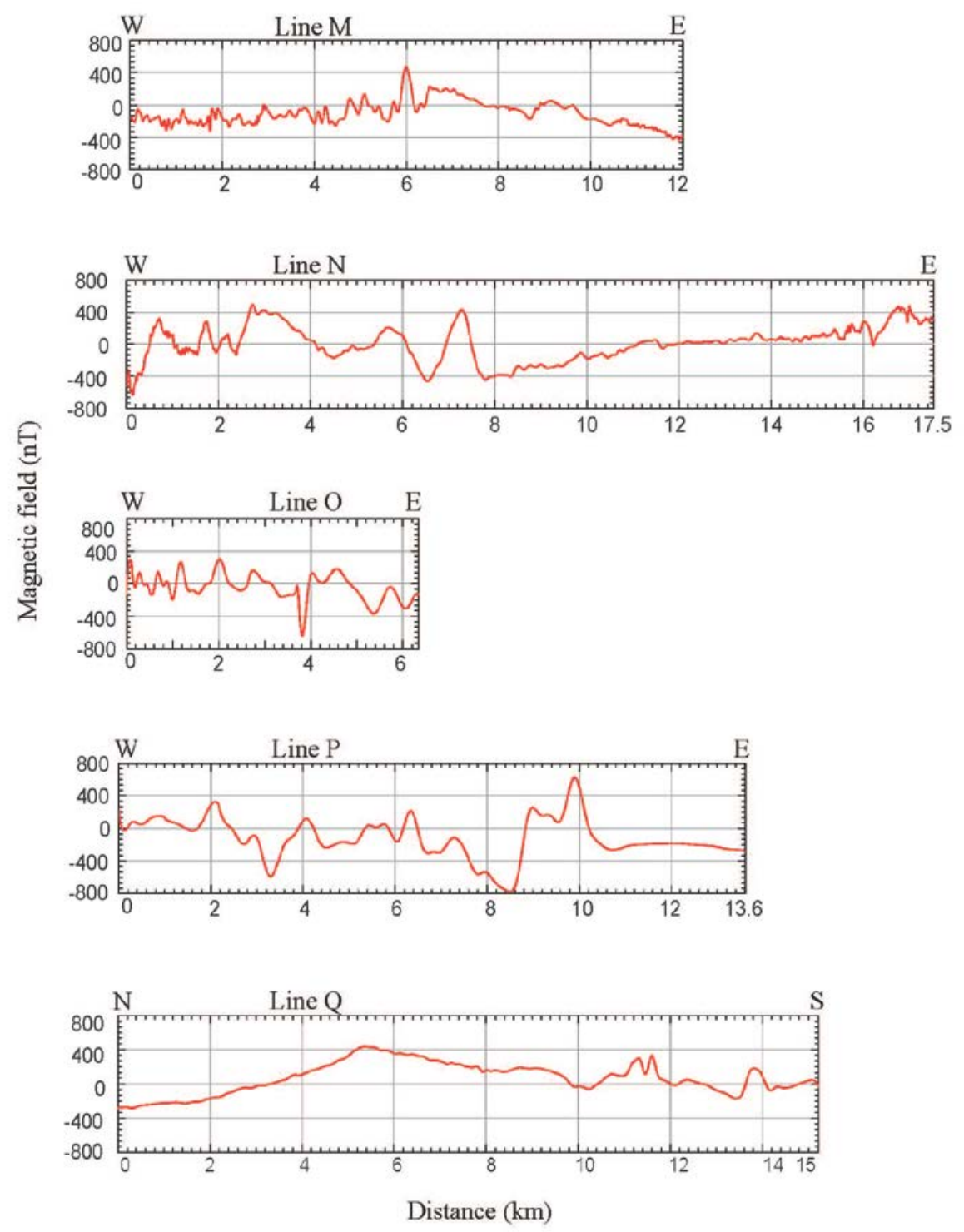